\title{
Phylogenetics, biogeography and classification of, and character evolution in, gamebirds (Aves: Galliformes): effects of character exclusion, data partitioning and missing data
}

- $\quad$ Timothy M. Crowe ${ }^{1,2, *}$,

- Rauri C. K. Bowie $e^{3}$,

- $\quad$ Paulette Bloomer,

- Tshifhiwa G. Mandiwana ${ }^{1,5}$,

- $\quad$ Terry A. J. Hedderson ${ }^{6}$,

- $\quad$ Ettore Randi ${ }^{7}$

- $\quad$ Sergio L. Pereira ${ }^{8}$ and

- Julia Wakeling ${ }^{1}$

$\bullet$

${ }^{1}$ DST/NRF Center of Excellence in Birds at the Percy FitzPatrick Institute, Department of Zoology, University of Cape Town, Private Bag Rondebosch 7701, South Africa;

${ }^{2}$ Department of Ornithology, American Museum of Natural History, Central Park West at 79th Street, New York, NY 10024-5192, USA;

${ }^{3}$ Department of Botany and Zoology, University of Stellenbosch, Private Bag X1, Matieland 7602, South Africa;

${ }^{4}$ Department of Genetics, University of Pretoria, Pretoria 0001, South Africa;

${ }^{5}$ Department of Ornithology, Transvaal Museum, Northern Flagship Institution, PO Box 413, Pretoria 0001, South Africa;

${ }^{6}$ Department of Botany, University of Cape Town, Private Bag X1, Rondebosch 7701, South Africa;

${ }^{7}$ Istituto Nazionale per la Fauna Selvatica, Laboratorio di Genetica, Via Cà Fornacetta 9, 40064 Ozzano Emilia (BO), Italy;

${ }^{8}$ Department of Natural History, Royal Ontario Museum, 100 Queen's Park, Ont., Canada M5S 2C6

\section{Abstract}

The phylogenetic relationships, biogeography and classification of, and morphobehavioral (M/B) evolution in, gamebirds (Aves: Galliformes) are investigated. In-group taxa (rooted on representatives of the Anseriformes) include 158 species representing all suprageneric galliform taxa and 65 genera. The characters include $102 \mathrm{M} / \mathrm{B}$ attributes and 4452 nucleic acid base pairs from mitochondrial cytochrome $b$ (CYT B), NADH dehydrogenase subunit 2 (ND2), 12S ribosomal DNA (12S) and control region (CR), and 
nuclear ovomucoid intron $\mathrm{G}(\mathrm{OVO}-\mathrm{G})$. Analysis of the combined character data set yielded a single, completely resolved cladogram that had the highest levels of jackknife support, which suggests a need for a revised classification for the phasianine galliforms. Adding $102 \mathrm{M} / \mathrm{B}$ characters to the combined CYT B and ND2 partitions (2184 characters) decisively overturns the topology suggested by analysis of the two mtDNA partitions alone, refuting the view that $\mathrm{M} / \mathrm{B}$ characters should be excluded from phylogenetic analyses because of their relatively small number and putative character state ambiguity. Exclusion of the OVO-G partition (with $>70 \%$ missing data) from the combined data set had no effect on cladistic structure, but slightly lowered jackknife support at several nodes. Exclusion of third positions of codons in an analysis of a CYT $B+\mathrm{ND} 2$ partition resulted in a massive loss of resolution and support, and even failed to recover the monophyly of the Galliformes with jackknife support. A combined analysis of putatively less informative, "non-coding" characters (CYT B/ND2 third position sites $+\mathrm{CR}+12 \mathrm{~S}+\mathrm{OVO}-\mathrm{G}$ sequences) yielded a highly resolved consensus cladogram congruent with the combined-evidence cladogram. Traditionally recognized suprageneric galliform taxa emerging in the combined cladogram are: the families Megapodiidae (megapodes), Cracidae (cracids), Numididae (guineafowls), Odontophoridae (New World quails) and Phasianidae (pheasants, pavonines, partridges, quails, francolins, spurfowls and grouse) and the subfamilies Cracinae (curassows, chachalacas and the horned guan), Penelopinae (remaining guans), Pavoninae sensu lato (peafowls, peacock pheasants and argus pheasants), Tetraoninae (grouse) and Phasianinae (pheasants minus Gallus). The monophyly of some traditional groupings (e.g., the perdicinae:

partridges/quails/francolins) is rejected decisively, contrasted by the emergence of other unexpected groupings. The most remarkable phylogenetic results are the placement of endemic African galliforms as sisters to geographically far-distant taxa in Asia and the Americas. Biogeographically, the combined-data cladogram supports the hypothesis that basal lineages of galliforms diverged prior to the Cretaceous/Tertiary (K-T) Event and that the subsequent cladogenesis was influenced by the break-up of Gondwana. The evolution of gamebirds in Africa, Asia and the Americas has a far more complicated historical biogeography than suggested to date. With regard to character evolution: spurs appear to have evolved at least twice within the Galliformes; a relatively large number of tail feathers $(\geq 14)$ at least three times; polygyny at least twice; and sexual dimorphism many times.

\section{(c) The Willi Hennig Society 2006.}

Cladistic analysis of taxonomic characters, i.e., features that are effectively invariant within (and variable among) the taxa under study (Nixon and Wheeler, 1990), is central to the inference of phylogenetic relationships among taxa and in developing meaningful 
systems of classification (Farris, 1983). Cladists who base their research on morphological and behavioral characters have little difficulty in deciding what to do $a$ priori with characters. They analyze them, seeking the most parsimonious cladistic hypothesis based on all phylogenetically informative character evidence (Farris, 1983; Kluge, 1989, 2004; Kluge and Wolf, 1993). However, in phylogenetic studies involving nucleic acid characters, especially in analyses of distantly related taxa, some molecular systematists recommend the exclusion, differential weighting or downgrading of some putatively relatively less informative characters to emphasize the contribution of those characters thought to possess stronger phylogenetic signal (Edwards et al., 1991; Irwin et al., 1991; Bull et al., 1993; Kornegay et al., 1993; Swofford et al., 1996; Bowie et al., 2005). For example, at various stages in their study of complete sequences of mitochondrial cytochrome $b$ (CYT B) from nine exemplar gamebird (chicken-like birds) species within the avian order Galliformes, Kornegay et al. (1993): (1) downgraded DNA sequence data to the amino acids for which they code; (2) excluded third position sites; and (3) downgraded first positions of all leucine codons to generic pyrimidines. The implementation of strategies 2 and 3, in their parsimony analyses, resulted in Kornegay et al. (1993) discarding all but 34 of 254 potentially phylogenetically informative characters. In other studies of similar scope, Edwards et al. (1991) and Cracraft and Helm-Bychowski (1991) employed another tactic, transversion analysis, by downgrading all sites to generic purines and pyrimidines.

Another possible a priori treatment of potentially phylogenetically informative data favors dividing molecular and other character data into "process partitions" (e.g., some molecular versus other molecular, or all molecular versus all organismal characters) and subjecting them to independent phylogenetic analysis and screening to determine if they are significantly homogeneous to allow meaningful phylogenetic interpretation as a single, combined data set (Bull et al., 1993; Nixon and Carpenter, 1996). Other systematists (e.g., Swofford, 1991; Lanyon, 1993; Miyamoto and Fitch, 1995) have taken a more severe view and maintain that data sets should not be combined if there is evidence of a lack of topological (= taxonomic) congruence (e.g., due to the effects of hybridization) when they are analyzed separately. More recently, Lecointre and Deleporte (2005) have argued for initial separate analysis of partitions to identify [e.g., through use of the Farris et al.'s (1994) incongruence length difference (ILD) test]"relevant" characters, i.e., those that are congruent between data sets. They then propose to treat incongruent data as missing in a combined analysis of all character partitions. Finally, many molecular systematists (e.g., Avise et al., 1994) conduct analyses using a variety of phylogenetic optimality criteria and then compare the topologies obtained from these different approaches, maintaining that topologies that are resilient to different methods of 
analysis are relatively more robust than those that vary depending on the method of analysis.

More recently, some molecular systematists have suggested that morphological and behavioral characters should be excluded from primary phylogenetic analyses, and should only be studied within the context of cladograms derived from the analysis of molecular characters only (Scotland et al., 2003). The primary justifications underpinning this suggestion are that the relatively large number of molecular characters will produce cladograms with greater accuracy and precision, and that molecular characters are inherently less "ambiguous" than the generally fewer morpho-behavioral (M/B) characters. In the present study, we investigate the empirical consequences of some of these systematic strategies by analyzing a range of character data partitions for gamebirds (Aves: Galliformes).

\section{Galliformes: taxonomy, classification and phylogeny}

Applying the relatively conservative (Cracraft, 1983) Biological Species Concept (Mayr, 1942), there are 281 currently recognized species of gamebirds within the Order Galliformes divided among 81 genera (Sibley and Monroe, 1990; del Hoyo et al., 1994; Hockey et al., 2005). These are currently assigned to seven families (Sibley and Ahlquist, 1985, 1990; del Hoyo et al., 1994; Table 1).

In the last comprehensive premolecular classification of birds of the world, Wetmore (1960) split the Galliformes into two superfamilies: (1) the Cracoidea-including two families, the megapodes (Megapodiidae) and cracids (Cracidae), and (2) the Phasianoidea -including four families, the grouse (Tetraonidae), quails, pheasants, peafowl, partridges and francolins (Phasianidae), guineafowls (Numididae) and turkeys (Meleagrididae). Research by Hudson et al. $(1959,1966)$ and Hudson and Lanzillotti (1964) based on studies of appendicular musculature supported Wetmore's classification. Based on cladistic interpretations of morphological and behavioral characters, Cracraft $(1981,1988)$ and Crowe $(1988)$ concluded that the cracids were sister to the balance of the phasianoids and not the megapodes, which they placed as basal within the order. This hypothesis was supported by more extensive M/B research by Brom and Dekker (1992) and Dyke et al. (2003), although the resolution in the latter's cladogram (Fig. 1) was poor within the guineafowls and other phasianine suprageneric clades due the remarkable osteological uniformity of "higher" galliforms, especially phasianids (Verheyen, 1956). Nevertheless, the most recent classification/phylogeny of the Galliformes that deals with all suprageneric taxa from both M/B and molecular perspectives (del Hoyo et al., 1994; Table 1) takes Wetmore (1960) position and places the families Megapodiidae and 
Cracidae as sister taxa within the suborder Cracini, and groups the balance of the taxa into five families (including the four recognized by Wetmore with the New World quails, Odontophoridae, accorded family status) into a sister suborder, the Phasiani. The phylogenetic status of the families comprising the Phasiani is unresolved in the cladogram presented in del Hoyo et al. (1994). The only phylogenetic resolution within the Phasiani is the partitioning of the Phasianidae into the sister subfamilies Phasianinae (pheasants, junglefowls, peafowls and allies) and Perdicinae (partridges, quails, francolins and spurfowls). Johnsgard (1973, 1986, 1988, 1999) provides a much more fully resolved suprageneric phylogeny (but somewhat different classification) for gamebirds (Fig. 2) based on a subjective evaluation of M/B information within which the still more fully resolved relationships among the megapodes follow those as suggested by Jones et al. (1995); cracids by Delacour and Amadon (1973) and guineafowls by Crowe (1978). Until we present our best-resolved phylogeny and a revised classification based thereon, the terminology given in Fig. 2 will be used.

A range of suprageneric phylogenetic investigations, covering different subsets of the gamebirds, have been undertaken with molecular data (e.g., Sibley and Ahlquist, 1972, 1985, 1990; Ho et al., 1976; Jolles et al., 1976; Helm-Bychowski and Wilson, 1986; Laskowski and Fitch, 1989; Randi et al., 1991; Kornegay et al., 1993; Avise et al., 1994; Sibley, 1994; Mindell et al., 1997; Kimball et al., 1999; Lucchini and Randi, 1999; Dimcheff et al., 2000, 2002; Armstrong et al., 2001; Ericson et al., 2001; Bush and Strobeck, 2003; Dyke et al., 2003; Pereira and Baker, 2006) (Fig. 3a-f). These have, at least in part, been reviewed by Crowe (1988), Sibley and Ahlquist (1990), Sheldon and Bledsoe (1993) and Pereira and Baker (2006). However, few of these studies have sampled species from all of the putative suprageneric taxa listed in Table 1, sampled multiple exemplars for these clades, or employed logical outgroups to root their cladograms. For example, Jolles et al. (1976) analyzed exemplars of only five in-group gamebird genera and used Homo sapiens as an outgroup. In fact, only Lucchini and Randi (1999) included more than 30 ingroup gamebird genera in their study, but were unable to include any cracids or a non-galliform outgroup in their research and rooted their cladogram (Fig. 3f) on a megapode. Furthermore, as with the M/B research of Dyke et al. (2003), many of these studies resulted in poorly resolved cladograms and/or clade nodes with low or no nodal support (Fig. 3d-f).

Thus, despite the existence of a relatively large body of potentially useful morphological, behavioral and molecular information, a well-resolved and supported cladogram adequately representing all putative gamebird suprageneric taxa has not been realized and there remains a lack of consensus on the phylogeny and classification of the group (Figs 1-3). The late Charles Sibley provides examples of extreme positions on 
classification. At one stage (Sibley, 1960), he suggested that only two families be recognized in a single order, but more recently (Sibley and Monroe, 1990), based on results of DNA-DNA hybridization studies, he maintained that one superorder, two orders, two suborders, two parvorders, two superfamilies and five families warrant recognition.

The phylogenetic status of the gamebirds at the onset of this study may be summarized thus. There is overwhelming morphological and molecular evidence (reviewed by Cracraft and Clarke, 2001; Mayr and Clarke, 2003; Fig. 3a,c) for the status of ducks, geese and screamers (Order Anseriformes) as the sister group of the Galliformes. Ericson (1996) and Ericson et al. (2001) challenged this sister relationship based on morphological and molecular evidence, but reversed this opinion (Ericson et al., 2001) once they became aware of the results of analyses of sequences of RAG-1, a nuclear protein-coding gene, by Groth and Barrowclough (1999). There is also general agreement on the monophyly of the order (Figs 1, 2 and 3a,c), although some studies based on immunological distances (Jolles et al., 1976, 1979; Prager and Wilson, 1976) suggested that Anas spp. of anseriforms might be more closely related to the balance of the gamebirds than are the cracids. There is also evidence for the monophyly of: the Megapodiidae (Birks and Edwards, 2002; Figs 1 and 3c), Cracidae (Pereira et al., 2002; Figs 1 and 3a,c); Numidinae (Crowe, 1978; Fig. 3a,c); Odontophorinae (Gutierrez et al., 1983; Figs 1 and 3d-f) and Tetraoninae (Gutierrez et al., 2000; Dimcheff et al., 2002; Drovetski, 2002; Figs 1 and 3c,e); and the basal divergence of megapodes and cracids within the order (Cracraft, 1981, 1988; Crowe, 1988; Garcia-Moreno et al., 2003; Figs 1 and 3a,c). Olson (1980) suggested that the megapodes might be cladistically relatively terminal, closer to the Phasianidae, but provided no cladistic evidence for this hypothesis. Like Wetmore (1960), Laskowski and Fitch (1989) and Sibley and Ahlquist (1990) concluded that megapodes and cracids are sister to one another (Fig. 3a), but this has not been supported by any other M/B or molecular research (e.g., Figs 1 and 3c). All published DNA-based molecular studies to date (except Armstrong et al., 2001; Fig. 3e) place the New World quails phylogenetically basal relative to the guineafowls (Fig. 3a,b,d,f), but generally without nodal support (Fig. 3a-d,f). It has also been suggested that the Phasianini and Perdicini as shown in Fig. 2 might not be monophyletic (Kimball et al., 1999; Fig. 3d; Lucchini and Randi, 1999; Fig. 3f; Bush and Strobeck, 2003; Pereira and Baker, 2006; Fig. 3c), but the cladograms in question generally lack adequate numbers of exemplars, and the clades concerned are poorly resolved and often lack nodal support. The one exception to this is the relatively decisive placement of Gallus (grouped with pheasants in Fig. 2) with or near to the bamboo partridges Bambusicola spp. (Fumihito et al., 1995; Fig. 3c-f). Furthermore, within the Perdicini 
sensuFig. 2, Crowe and Crowe (1985), Crowe et al. (1992) and Bloomer and Crowe (1998) presented evidence that questioned, but did not decisively reject, the monophyly of the francolins (Francolinus sensuHall, 1963; Sibley and Monroe, 1990; del Hoyo et al., 1994; Dyke et al., 2003), the largest (41 species) genus within the Galliformes (del Hoyo et al., 1994). Crowe et al. (1992) and Bloomer and Crowe (1998) split Francolinus into several genera (analyzed separately here) divided between two major groups, the francolins (Francolinus, Peliperdix, Dendroperdix and Scleroptila spp.) and spurfowls (Pternistis spp. sensuLittle and Crowe, 2000). Another novel, but once again tentative, hypothesis that emerges from Fig. 3 is that the gray partridge (Perdix perdix), wild turkey (Meleagris gallopavo) and grouse (Tetraoninae) might be related cladistically (Fig. 3a,c,d,f).

\section{Biogeography}

There is perhaps an even greater lack of consensus on the biogeographical relationships of gamebirds than on their phylogenetic relationships. Based on the presence of putative stem group Eocene galliform and Oligocene cracid fossils in North America (Tordoff and Macdonald, 1957; Mayr and Weidig, 2004) and Eocene and Oligocene fossil megapodes from Europe (Mourer-Chauvire, 1992), Vuilleumier (1965), Delacour and Amadon (1973), Olson (1980) and Mayr and Weidig (2004) hypothesized that these galliform families have their biogeographical origins in the Northern Hemisphere and that stem galliforms originated only after the Cretaceous-Tertiary mass extinction event (65 Ma). Crowe (1978) speculated that guineafowls were derived from a francolin-like ancestor that dispersed from Asia to Africa in the mid-Miocene. However, based on reassessments of the above-mentioned fossils by Crowe and Short (1992) and Dyke (2003), assessments of newly discovered Eocene galliform fossils from North America (Gulas-Wroblewski and Wroblewski, 2003) and Europe (Lindow et al., in review) and on morphological (Cracraft, 1981; Crowe, 1988; Dyke et al., 2003) and molecular clock (Cracraft, 2001; Groth and Barrowclough, 1999) phylogenetic analyses, a Southern Hemisphere origin prior to, or relatively soon after, the Cretaceous-Tertiary event is supported. Moreover, there is now a definite anseriform fossil from the late Cretaceous of Antarctica (Clarke et al., 2005). Furthermore, research based on analyses of mtDNA sequences by Van Tuinen and Dyke (2004) and Pereira and Baker (2006) using the ages of some of the above-mentioned fossil galliforms as calibration anchorpoints has produced molecular clock phylogenies that also suggest that the gamebirds originated on Gondwana and that the basal megapodes, cracids and, probably, the New World quails originated in the Cretaceous. 


\section{Aims and approach}

Our aims in this study were to: analyze existing and new information on a range of $\mathrm{M} / \mathrm{B}$ and molecular characters to infer the suprageneric phylogenetic relationships within the Galliformes; investigate congruence among the $\mathrm{M} / \mathrm{B}$ and molecular data partitions; evaluate the effects of character exclusion and missing data on cladogram topology and nodal support; offer a phylogenetic classification of the Galliformes; investigate the evolution of $\mathrm{M} / \mathrm{B}$ characters in galliforms and explore the biogeographical implications of the phylogeny.

\section{Materials and methods}

\section{Taxon sampling}

Taxa studied herein (Appendix 1) include 158 galliform (of 281 currently recognized) species representing all suprageneric galliform taxa and 65 of 81 genera and multiple representatives of all suprageneric taxa ascribed to the Galliformes (Johnsgard, 1973, 1986, 1988, 1999; Sibley and Monroe, 1990; del Hoyo et al., 1994; Hockey et al., 2005) are included. The choice of outgroups on which to root cladograms is based on the assumption that the Anseriformes (ducks, geese and screamers) are sister to the Galliformes (Sibley and Ahlquist, 1990; Groth and Barrowclough, 1999; Cracraft and Clarke, 2001). The exemplars used as outgroups are the magpie goose Anseranas semipalmata and two screamers Chauna torquata and Anhima cornuta.

\section{Character sampling}

\section{Morpho-behavioral characters}

The taxa were scored for the $102 \mathrm{M} / \mathrm{B}$ characters employed by Dyke et al. (2003). All multistate $\mathrm{M} / \mathrm{B}$ characters were treated as ordered in accordance with Dyke et al. (2003).

\section{Molecular characters}

Molecular characters include published and unpublished DNA sequences of nuclear ovomucoid G intron (OVO-G: $n=492$ bp including insertions/deletions) and mitochondrial CYT B ( $n=1143 \mathrm{bp})$, NADH dehydrogenase subunit 2 (ND2: $n=1041 \mathrm{bp}$ ) gene, $12 \mathrm{~S}$ rDNA (12S - preferred alignment $=731 \mathrm{bp}$ including insertions/deletions) and the control region (CR: preferred alignment $=1030 \mathrm{bp}$ including insertions/deletions) (Appendix 2). 


\section{Laboratory techniques}

DNA was extracted from blood, heart or liver tissue using the DNeasy animal tissue protocol provided with the DNeasy tissue kit (Qiagen, Valencia, CA). Primers used for PCR amplification and sequencing of CYT B, NADH2 and OVO-G are indicated in Table 2. Galliform-specific primers were designed (Table 2) for Pternistis griseostriatus and P. leucoscepus, because the initial CYT B primer pair (L14578, H16065) did not amplify. All primers are numbered according to the position of the 3' base of the primer in the complete chicken mitochondrial DNA genome (Desjardins and Morais, 1990).

Double-stranded DNA templates were amplified by the polymerase chain reaction (PCR) using 0.75 units of BIOTAQ DNA polymerase (Bioline, Randolph, MA) in $30 \mu \mathrm{L}$ reactions. Reactions also contained $1 \times \mathrm{NH}_{4}$ buffer, $2.5 \mathrm{mM} \mathrm{MgCl}_{2}$, each $\mathrm{dNTP}$ at $0.1 \mathrm{mM}$ and each primer at $0.3 \mu \mathrm{M}$. Three microliters of the undiluted and unquantified DNA extraction were used as template. The thermal profile used for all three DNA regions comprised an initial denaturation step at $94{ }^{\circ} \mathrm{C}$ for $2 \mathrm{~min}$, followed by 30 cycles of $94{ }^{\circ} \mathrm{C}$ for $1 \mathrm{~min}, 52{ }^{\circ} \mathrm{C}$ for $1 \mathrm{~min}$ and $72{ }^{\circ} \mathrm{C}$ for $2 \mathrm{~min}$, with a final extension step of $72{ }^{\circ} \mathrm{C}$ for 7 min. The PCR cycling was performed by a GeneAmp PCR System 2700 (Applied Biosystems, Foster City, CA).

Amplified products were cleaned from solution or gel using the GFX PCR-DNA and gel band purification kit (Amersham Biosciences, Little Chalfont, UK) prior to cycle sequencing with the ABI PRISM Big Dye Terminator V3.1 cycle sequencing Ready Reaction Kit (Applied Biosystems). Sequencing products were resolved on an ABI PRISM 3100 Genetic Analyzer. Sequences were assembled and checked for incorrect base calling and the presence of stop codons using SeqMan II (LaserGene systems software, DNAstar, Inc.) or Sequencher (GeneCodes, Ann Arbor, MI). Consensus sequences were aligned by Clustal X (Thompson et al., 1997) and adjusted manually using MegAlign (LaserGene systems software, DNAstar, Inc., Madison, WI). The alignment of $12 \mathrm{~S}$ rDNA and control region sequences was done in Clustal X (Thompson et al., 1997) using several different gap opening and gap extension penalties. The preferred alignment, including insertions/deletions for the $12 \mathrm{~S}$ partition included $731 \mathrm{bp}$ and indels. The aligned control region sequence ( $n=1046 \mathrm{bp}$ plus indels) was then

adjusted manually in regions of hypervariability and length heterogeneity within domains I and III in accordance with Lucchini and Randi (1999).

\section{Analytical approaches: parsimony}

Each of the six data partitions (Table 3, M/B, CYT B, ND2, 12S, CR, OVO-G) was analyzed independently and as a single combined data set. The DNA-based partitions 
were also analyzed in combination in contrast to the M/B partition. In order to assess the effects of adding a partition with large amounts of missing data, the combined analysis was run minus the OVO-G partition, which had more than $70 \%$ missing data. To assess any potential cladistic variation between $\mathrm{M} / \mathrm{B}$ and DNA-based data, all DNA partitions were combined and analyzed simultaneously. To determine the relative phylogenetic merits of DNA characters that influence the amino acids produced, the two coding partitions (CYT B and ND2) were analyzed in combination stripped of their third codon position bases. Finally, a "non-coding" partition (third positions of CYT B and ND2, 12S, $\mathrm{CR}$ and OVO-G sequences) was analyzed to explore the utility of characters less constrained by biochemical function in recovering a meaningful cladogram.

All parsimony-based phylogenetic analyses were conducted using Winclada version 0.9.99m24 (BETA) (Nixon, 1992) and Nona Version 2.0 (Goloboff, 1993). The search strategy employed was the default Ratchet Island Hopper option: 200 iterations/rep; one tree to hold/iteration; four characters to sample, amb-poly, and random constraint level 10. When multiple, equally parsimonious cladograms persisted, a strict consensus cladogram was constructed. The extent to which each non-terminal node is supported by character data was determined by using the "jackknife" program XAC (Farris et al., 1996; Källersjö et al., 1998) using the following strategy: 1000 replications, branch swapping switched on, random addition of five sequences per replicate, and $p=e^{-1}$ (about 37\%) of the characters deleted per jackknife replicate. We assessed the pair-wise congruence between the various data partitions and between combinations of partitions (e.g., combined DNA partitions versus the M/B partition and nuclear OVO-G partitions versus the combined mitochondrial DNA partitions) with the Winclada implementation of the ILD test (Farris et al., 1994).

\section{Bayesian inference}

Model-based analyses were conducted on a truncated data set of 66 taxa that had DNA sequence data for at least three of the five molecular partitions (Appendix 1). Modeltest 3.6 (Posada and Crandall, 1998) was used to determine which model of nucleotide evolution was most appropriate for each of the five data partitions. Under the Akaike Information Criterion variants of the General Time Reversible Model (GTR) were identified as most appropriate for each of the five data partitions. MrBayes 3.1 (Ronquist and Huelsenbeck, 2003) was used to undertake the Bayesian approach to phylogenetic inference (BI). Four Metropolis-coupled MCMC chains (one cold and three heated chains) were run simultaneously to optimize efforts to find peaks in tree-space. Initially, two runs each of 2 million generations were implemented under the GTR model of nucleotide substitution, employing a gamma distribution (estimated using four rate 
categories) and estimation of the proportion of invariable sites implemented $(\mathrm{GTR}+\mathrm{I}+\mathrm{G})$ to accommodate site-to-site variation in evolutionary rates. A separate set of parameters was estimated for each data partition (i.e., the data partitions were unlinked, Appendix 3). The average standard deviation of the split frequencies was 0.0134 . This search strategy was repeated in a single run of 5 million generations. Each run started from a random tree and set of initial parameters. A Dirichlet distribution was assumed for estimation of the base frequency parameters and an uninformative (flat) prior was used for the topology. Trees were sampled every 100 or 250 generations in the 2 million and 5 million generation runs, respectively. This resulted in a sample of 20001 trees for each analysis. A conservative approach was adopted for estimating the number of cycles to discard (the burn-in) and was set as $20 \%$ (4001 trees).

\section{Character evolution}

Based on information from del Hoyo et al. (1994), the presence of four characters reputed to be under the influence of sexual selection (spurs, a large number of tail feathers, polygynous mating system and sexual plumage/integument dimorphism) (Andersson, 1994) were mapped on to our best resolved cladogram.

\section{Divergences inferred from a galliform relaxed molecular "clock"}

Estimation of divergence times requires calibration against fossils of known age. We used the ages of two galliform fossils that have been placed cladistically to calibrate this clock: Gallinuloides wyomingensis (54 Ma) and Amitabha urbsinterdictensis (50 Ma). Crowe and Short (1992) and Dyke (2003) consider Gallinuloides to be a crown-group galliform and the former authors placed it as sister to the phasianines, i.e., New World quails and non-numidine phasianids sensudel Hoyo et al. (1994). Based on assessment of 39 of the $102 \mathrm{M} / \mathrm{B}$ characters employed in the present study, Dyke (2003) placed Gallinuloides at the stem of the Phasianoidea: phasianines plus the guineafowls, Numididae sensudel Hoyo et al., 1994). Gulas-Wroblewski and Wroblewski, 2003) place Amitabha at the stem of the phasianines. Mayr and Weidig (2004) and Mayr (2005) dispute the placement of Gallinuloides and Amitabha within the crown Galliformes, and place them as stem-group Galliformes, cladistically basal to all modern galliforms based largely on its possession of a cup-like scapular articulation facet on the coracoid (a plesiomorphic character within neornithines that is also present in Anseriformes). Based on a reassessment of the original Gallinuloides fossil specimen and investigations of the second specimen described by Mayr and Weidig (2004) and a new gallinuloid fossil from Lower Eocene deposits in Denmark, Lindow et al. (in review) were able to score Gallinuloides for 52 of the $102 \mathrm{M} / \mathrm{B}$ characters assessed by Dyke et al. (2003) and reassessed characters that Mayr and Weidig (2004) suggested were coded incorrectly. 
Parsimony-based cladistic analysis of this new, larger matrix (Lindow et al., in review) once again places Gallinuloides with the crown Galliformes and basal to the phasianoids.

The cladogram based on all data combined was the most resolved and best supported and we subsequently accepted this as the best estimate of phylogeny. Therefore we constrained each of the independent data sets to this topology. These analyses were also restricted to the 66 taxa for which the DNA partitions were relatively well-sampled (Appendix 1). The hypothesis of rate constancy was tested for each data set using likelihood ratio tests between rate-constrained and unconstrained trees, and in each case constancy could be rejected $(P<0.02)$.

We estimated ages in three ways. In the first two cases, branch lengths were estimated for each data set under (1) parsimony, and (2) under the likelihood models described for each data set above. In each case, ultrametric trees were produced for each data set using Sanderson's (1997) non-parametric rate smoothing (NPRS) approach as implemented in Tree Edit (Rambaut and Charleston, 1999). The trees were then scaled using the $54 \mathrm{Ma}$ date for the split between guineafowls and other phasianoid birds from megapodes and cracids. Of the possible calibration ages available, we used this split since it is relatively close to the critical nodes that we wished to estimate. Divergence of age estimates from "true ages" tends to increase with distance from the calibration point under most smoothing techniques (e.g., Wikstrom et al., 2001).

In addition, the posterior distribution of divergence times was also approximated under a Bayesian approach (Thorne and Kishino, 2002). For each molecular partition, maximum likelihood estimates of the transition/transversion ratio, nucleotide frequencies and shape parameter of a five-category gamma distribution for among-site rate variation were obtained in PAML 3.14 (Yang, 1997). These estimates were used to obtain a matrix of branch length variance - covariance for each gene, using the ESTBRANCHES program in the MULTIDISTRIBUTE package (available from J. Thorne, North Carolina State University). These matrices were then integrated to account for each partition's uncertainty in branch length estimates and used to approximate the Bayesian posterior distribution of divergence times in the MULTIDIVTIME program in MULTIDISTRIBUTE. The following priors were set in the MULTIDIVTIME analysis: expected time between the tip and the ingroup root $(\mathrm{rttime})=95.0 \mathrm{Ma}$, with standard deviation (SD) = 20 Ma based on a molecular time estimate of Pereira and Baker (2006) obtained from mitochondrial DNA sequence data; rate of the root node (rtrate) and its $\mathrm{SD}=0.04$ substitution per site per unit time, determined as the median of all the tip-toroot branch lengths for each gene divided by rttime; rate of change between ancestral and descendant nodes (brownmean) $=0.105$. Because $a$ priori information for rtrate and 
brownmean are largely unknown, the SD was set as the same values to allow a gene to have a priori a large variation in rate at the node and rate change over time (Thorne and Kishino, 2002). The analysis was repeated three times, each starting with a randomly selected initial state, to check for convergence of the Markov chain. For each run, the first 5000 cycles of the chain were discarded, and a sample was taken every 1000 cycles to a total of 10000 samples. Convergence of the Markov chain was assessed by comparing the mean Bayesian posterior distribution of divergence times and their $95 \%$ credible interval among the three independent runs, and checking whether the first three figures of the proportion of successful changes for all parameters estimates were similar.

For the Bayesian analysis, data from the fossil record were also used to provide minimum time constraints as follows: stem Phasianines, i.e., New World quails and non-numidine phasianids sensudel Hoyo et al. (1994), set at 50 Ma based on the fossil Amitabha placed at the stem of the phasianines (Gulas-Wroblewski and Wroblewski, 2003); stem phasianoids at 54 Ma following Crowe and Short (1992), Dyke (2003) and Lindow et al. (in review) that placed Gallinuloides wyomingensis (54-55 Ma) as sister to phasianines in a phylogenetic context [contraMayr and Weidig (2004) and Mayr (2005)]; stem cracids and the separation of the clades containing Gallus and Coturnix were both set to a minimum of $35 \mathrm{Ma}$ as based on Procrax (Tordoff and Macdonald, 1957) and Schaubortix (Brodkorb, 1964), respectively. Because a maximum time constraint is advisable for at least one node in the tree, and the fossil record does not provide this information for Galliformes, we set a maximum of 123 Ma for the age of crown Galliformes based on the upper limit of the $95 \%$ credible interval obtained by Pereira and Baker (2006) using mitochondrial DNA sequences.

\section{Results}

\section{Phylogenetic congruence between the character partitions}

None of the pair-wise ILD test comparisons between character partitions yielded statistically significant results, suggesting the absence of phylogenetic incongruence between any of the partitions. Furthermore, there were no significant results for the comparisons between the $\mathrm{M} / \mathrm{B}$ partition and the combined DNA partitions, and between the nuclear DNA partition (OVO-G) and the four mitochondrial partitions (CYT B, ND2, $\mathrm{CR}, 12 \mathrm{~S})$ combined. 


\section{Phylogenetic analyses: traditional clades}

\section{Combined data (COMB)}

The analysis of the combined data set (now with our proposed suprageneric taxonomic terminology) yielded the best resolved and a generally well-supported phylogeny (Table 4) with one most parsimonious tree (length $=18$ 598; $\mathrm{CI}=22 ; \mathrm{RI}=65$ ) which is presented (with genera as terminals) in Fig. 4 annotated with information on jackknife and Bayesian support, classification and biogeography. In this cladogram, the megapodes are basal (with high jackknife support) followed sequentially by the cracids, guineafowls, New World quails and then the balance of phasianine galliforms (all with high jackknife support). Within this phasianine clade, traditionally recognized suprageneric taxa that emerge with support are the pavonines (peafowls + argus pheasants + peacock pheasants $=$ Pavoninae sensu lato), grouse (Tetraoninae) and pheasants minus the junglefowls (Gallus spp.) (Phasianinae), although the basal portion of the pheasant clade lacks jackknife support.

\section{Bayesian inference of phylogenetic relationships}

The resulting tree based on all DNA partitions combined is essentially the same (with very high posterior probability support) at the suprageneric level as the parsimony tree for all partitions combined (Fig. 4), and the nodes are supported by high posterior probabilities (Fig. 4; Table 4 under "All DNA" column). The only differences are within the phasianines. Peacock pheasants (Polyplectron spp.) are unresolved within the phasianids and the turkey (Meleagris) and gray partridge (Perdix) are not sister taxa. The turkey is sister to grouse, and the gray partridge to gallopheasants and allies.

\section{Effects of missing data (COMB minus OVO-G, C-OG)}

When the OVO-G partition (with $>70 \%$ missing data) is excluded from the combined analysis, there are no topological changes in the cladogram, but nodal support drops for several nodes (Table 4).

\section{Cytochrome b}

The resulting strict consensus cladogram (Fig. 5) differs markedly from those generated by previous analyses of CYT B sequences (Kornegay et al., 1993; Avise et al., 1994; Kimball et al., 1999) and analyses of most of the other DNA partitions and the combined data set (Table 4). The cracids and megapodes remain basal, but contrary to previous CYT B-based studies the cracids are basal (with jackknife nodal support) relative to the megapodes. Furthermore, as in Sibley and Ahlquist's $(1985,1990)$ DNA-DNA 
hybridization study and the Kornegay et al. (1993) CYT B-based study, the New World quails are basal (but without support) relative to the guineafowls. The balance of the phasianines follows, with support. Within this phasianine clade, no currently recognized suprageneric grouping is recovered in total with support. Even the normally well supported grouse (Table 4). In fact, Bonasa bonasia and B. sewerzowi cease to link with Bonasa umbellus, but are sister to the turkey Meleagris. Within the Phasianinae, the gallopheasants and allies are recovered with support. The francolins and spurfowls are not monophyletic. All spurfowls form a monophyletic assemblage within the genus Pternistis, but the francolins are polyphyletic.

\section{NADH2 (ND2)}

The strict consensus ND2 cladogram (Fig. 6) parallels that of the combined analysis, but the jackknife support for the New World quails as being terminal relative to the guineafowls is low (54) (Table 4). The megapodes, cracids, guineafowls and New World quails are recovered with support. Within the phasianine clade only the grouse are recovered in total with support (Table 4). The pheasants (minus Gallus) form a paraphyletic assemblage, with only the gallopheasants and allies grouped as monophyletic with support.

\section{Control region (CR)}

The strict consensus CR cladogram (Fig. 7) places the cracids basal to the phasianoids with jackknife nodal support. The next most basal assemblage is an unresolved, unsupported polytomy comprising Numida, Xenoperdix, Arborophila and the New World quails that is basal to the balance of the phasianines. Within the phasianine clade, none of the traditional clades are recovered, although subsets of the pavonines, grouse and pheasants, e.g., gallopheasants and allies form monophyletic assemblages with support. Once again, the grouse do not form a monophyletic group, with Bonasa umbellus now in an unresolved position.

\section{S rDNA (12S)}

The strict consensus $12 \mathrm{~S}$ cladogram (Fig. 8) has topological similarities with both the CYT B and COMB cladograms. As in the COMB cladogram, the megapodes are basal relative to the cracids, but without jackknife nodal support. Also as in the cladogram for the combined data (Fig. 4), the guineafowls are basal relative to the New World quails, but also without support. Within the phasianines, only the grouse emerge with support (Table 4). 


\section{Ovomucoid G (OVO-G)}

The OVO-G strict consensus cladogram (Fig. 9) differs markedly from that of Armstrong et al. (2001; Fig. 3e) and those generated for the other partitions. Rooted on a megapode, it places the two cracids as basal relative to the remaining exemplars, but without jackknife support. Then Xenoperdix (two species of small partridges from three Eastern Arc mountains in Tanzania — Dinesen et al., 1994; Bowie and Fjeldså, 2005), emerges (without support) as basal to the balance of the gamebirds. The only traditional groupings recovered with support in the remainder of the cladogram are the guineafowls and New World quails (that are now sister taxa without support), grouse and the francolins sensu strictu.

\section{All DNA partitions combined}

The ALL-DNA cladogram parallels that for the combined data (Table 4; Fig. 4) exactly, except that it does not recover the pavonines in toto as a single clade, but rather as a paraphyletic assemblage.

\section{CYT B +ND2 minus third position nucleotides (CYT B + ND2 no. 3P)}

This composite "coding" partition cladogram is the least resolved and worst supported of all (Table 4). It even fails to recover the gamebirds as a monophyletic group with support. In the strict consensus cladogram, the megapodes are monophyletic (with support) and basal (without support) followed by the cracids (without support). Indeed, the monophyly of the normally cladistically resilient cracids also fails to have jackknife support. The remaining taxa form a massive polytomy (Table 4) within which the only suprageneric groups emerging are the guineafowls, New World quails, grouse and gallopheasants and allies, generally without support.

"Non-coding" data (CYT B/ND2 3 P + CR, OVO-G, 12S)

Contrary to the view that third positions and non-coding DNA are not useful in recovering deep basal lineages, analysis of the combined CYT B/ND2 third position $+\mathrm{CR}+12 \mathrm{~S}+$ OVO-G partitions recovers a strict consensus cladogram remarkably congruent with that produced by analysis of all partitions combined (Table 4).

\section{Traditional groups sundered}

The demise of the Perdicinae (partridges/quails/ francolins) and francolins sensu lato 
The only traditional groups of gamebirds traditionally presumed monophyletic (Fig. 2) that are not recovered in the combined partition analysis are the Perdicinae and francolins sensu lato ( $\mathrm{P}$ and francolins and Pternistis in Fig. 4). In Figs 5-9, some partridges and the Old World quails form a paraphyletic assemblage, linking with spurfowls (Pternistis spp.). Other partridges (minus Perdix) and the francolins (Francolinus, Peliperdix, Dendroperdix and Scleroptila spp.) form a monophyletic group with the bamboo partridges (Bambusicola spp.) and junglefowls (Gallus spp.).

\section{Non-traditional groupings (summarized in Table 4)}

\section{Sister group relationship between megapodes and cracids}

None of the analyses indicate a sister relationship between the megapodes and cracids (Figs 4-9, Table 4). The megapodes are generally placed basal within the Galliformes with the cracids branching off next as sister to the balance of galliforms.

\section{Xenoperdix/Rollulus/Arborophila clade sister to balance of phasianine galliforms}

This clade appears as sister to the phasianines in the CYT B and $12 \mathrm{~S}$ cladograms (Figs 5 and 8), but only with high jackknife support (100) in the combined cladogram (Fig. 4) and that based on analyses of all DNA partitions combined (99) (Table 4). In the analysis of the ND2 partition (Fig. 6), this clade appears within the Ptilopachus/New World quail clade, but without support.

\section{Madagascar partridge (Margaroperdix madagarensis) sister to common quail (Coturnix coturnix)}

These two taxa are strongly supported as sisters in analyses of both molecular partitions in which they are represented (CYT B, Fig. 5; CR, Fig. 7) (Table 4).

\section{Bamboo partridge (Bambusicola) sister to junglefowls (Gallus)}

This sister relationship was found in the analysis of the M/B (Fig. 1) and CYT B and ND2 partitions (Figs 5 and 6, without support), in the 12S (Fig. 8) and OVO-G partitions (Fig. 9) (with support), and in the combined DNA (Fig. 4) and All DNA analyses with support (Table 4).

\section{The gray partridge (Perdix perdix) sister to the wild turkey (Meleagris gallopavo)}

These taxa are sisters (with support) in the combined cladogram (Fig. 4), and the All DNA and ND2 (Fig. 6) cladograms in the parsimony analyses (Table 4). In the Bayesian analyses, the grey partridge is sister to pheasants and the wild turkey to grouse. 


\section{Character evolution}

The presence of spurs, $\geq 14$ tail feathers, sexual dimorphism and polygynous mating system in the gamebird genera represented here is shown in Fig. 10.

\section{Inferred dates of divergence}

Estimates of the dates of divergence of selected galliform clades are given in Table 5. All of the divergence estimates suggest that the Galliformes, megapodes and cracids diverged prior to the K-T Event. The 95\% credible intervals on age estimates from the Bayesian analysis do not exclude the possibility that guineafowls and phasianids also diverged prior to the K-T event. Except for the split of the lineages leading to megapodes and cracids, NPRS and the Bayesian method result in similar estimates of divergence times. The differences observed at the oldest nodes are a reflection of how the fossil age was used in the NPRS and Bayesian methods. The former method uses fossil data as a fixed, minimum age of $54 \mathrm{Ma}$ for Numididae, whereas the latter integrates several fossil data as a priori time constraints to obtain estimates of divergence times and assumes a priori an age for crown Galliformes around $95 \mathrm{Ma}$ (Pereira and Baker, 2006). Moreover, branch lengths provided by the NPRS methods under parsimony are likely to underestimate the number of substitutions, especially along older branches such those at the origin of megapodes and cracids, and therefore underestimate the age of older divergences.

\section{Discussion}

\section{To partition or not to partition?}

As none of the pair-wise ILD tests between all partitions (and combinations thereof) and between the $\mathrm{M} / \mathrm{B}$ partition and that for all DNA-based partitions combined yielded significant results suggesting incongruence, there is no statistically justifiable reason for maintaining the partitions as separate phylogenetic entities. Indeed, the single most parsimonious cladogram for the combined data (Fig. 4) is the most fully resolved one (Table 4) and, with very few exceptions (and almost always only when the M/B and DNA partition data clashed), had the highest nodal jackknife support values (Table 4). Therefore, although analysis of no single partition on its own produces a well-resolved cladogram that recovers suprageneric taxa with high nodal support, they complement one another in the combined analysis cladogram (Fig. 4), which does precisely that, supporting the position that the most powerful cladistic hypothesis is that based on all 
characters analyzed together (Kluge, 1989; Kluge and Wolf, 1993; Freundenstein et al., 2003; Kluge, 2004).

\section{Character exclusion}

Excluding the OVO-G partition (with $>70 \%$ missing data) from the combined data partitions had no effect on the cladistic structure, but resulted in slightly lower jackknife support at several nodes (Table 4). So, it appears that, provided that data partitions with missing entries have adequate taxic representation and there is sufficient information for informative characters, they can contribute to cladistic analyses (Kearney and Clarke, 2003; Wiens, 2003, 2005). Furthermore, the utility of separate analysis of characters thought to be phylogenetically more reliable (e.g., first and second positions of DNA codons) is unjustifiable (at least for gamebirds) because it produced the least resolved tree with the lowest (or absent) values of nodal jackknife support (Table 4). Indeed, excluding the third positions from the CYT B/ND2 combined partitions results in a loss of more than half of the phylogenetically informative characters. Furthermore, separate analysis of all the putatively less informative characters (e.g., DNA third codon positions and non-coding DNA) often excluded from, or downweighted in, molecular phylogenetic analyses produced a well-resolved cladogram remarkably congruent with that produced through analysis of all characters combined (Table 4). Thus, third codon positions and non-coding DNA provide the bulk of informative characters, cladistic structure and support in this study.

\section{The value of morpho-behavioral data}

The $102 \mathrm{M} / \mathrm{B}$ characters of Dyke et al. (2003) played a pivotal phylogenetic role in this research. This is best illustrated in the guineafowls-versus-New World quails-basal debate. Based on their DNA-DNA hybridization studies Sibley and Ahlquist (1985, 1990) maintain that the New World quails are not crown galliforms most closely related to Old World quails and/or partridges (Crowe, 1988; Dyke et al., 2003), but form a basal taxon (relative to the guineafowls). Analyses based on mtDNA sequences by Kornegay et al. (1993 - CYT B), Avise et al. (1994 — CYT B), Kimball et al. (1999-CYT B), Lucchini and Randi (1999—CR) and Pereira and Baker (2006 — CYT B, ND2, 12S rDNA) took a similar position. In contrast, Dimcheff et al. (2002) found the guineafowls to be basal (or sister to) to New World quails, also based on analyses of mtDNA sequences (CYT B, ND2). However, with the much larger taxon sampling in our study, the analysis of the CYT $B$ partition actually fails to resolve this node with jackknife support (Fig. 5). That for ND2 places the guineafowls basal with high jackknife support (99) (Fig. 6), and that for a combined CYT B + ND2 + 12S partition place the guineafowls basal with a support value of 100 (Table 4). Furthermore, adding 
information from the $102 \mathrm{M} / \mathrm{B}$ characters to that of the two coding mtDNA partitions (CYT B, ND2 with more than 10 times the number of phylogenetically informative characters - Table 3) also results in a cladogram that strongly supports a basal position for the guineafowls (jackknife nodal support $=100$ ), followed by the New World quail/Ptilopachus clade (support = 79). In the combined cladogram, the support for this node rises to 100 (Fig. 4; Table 4). Indeed, Harshman (1994) had already highlighted the fact that the internode between the New World quails and the guineafowls in Sibley and Ahlquist's (1985, 1990) DNA-DNA hybridization cladograms was extremely short and of debatable decisiveness. Cox et al. (in press) have also reached the same phylogenetic conclusion based on analyses of eight nuclear loci and three mitochondrial regions. Thus, contraScotland et al. (2003), at least for the gamebirds, M/B characters can provide decisive, relatively unambiguous information in cladistic analysis, albeit in this case primarily at the basal nodes of the cladogram. Indeed, much of the phylogenetic ambiguity, at all levels, comes from the molecular characters.

\section{Congruence between the combined-partition and published cladograms}

The topology of the combined partition cladogram (Fig. 4) supports the monophyly of all of the Johnsgard's suprageneric clades depicted in Fig. 2 except the Perdicini, which is polyphyletic, and the Phasiani from which the pavonines and Gallus are removed. Gallus is placed into one of the perdicine subclades with the pavonines placed sister to it. It differs from the M/B cladogram of Dyke et al. (2003; Fig. 1) in that it resolves the relationships of phasianoid gamebirds much more fully and generally with jackknife support. Furthermore, in the M/B cladogram (Fig. 1): the guineafowls are paraphyletic; Polyplectron is not placed with the pavonines; the New World quails are sister to Old World quails and partridges and not to the entire phasianine clade; the francolins and spurfowls are mono- and not diphyletic; and the pheasants and perdicines are paraphyletic or unresolved. One interesting congruent result is that Bambusicola and Gallus are sister taxa in both M/B cladograms contra to the traditional placement of Gallus with pheasants (Fig. 2).

The combined partition cladogram differs from some, most or all of the relatively taxonpoor DNA-based cladograms (Fig. 3a-f) in that the megapodes and cracids are not sisters and the guineafowls are basal relative to the New World quails. Furthermore, none of the DNA-based cladograms shown in Fig. 3 resolve phasianines decisively with support. In fact, the cladogram for the control region partition (Fig. 7), the molecular partition for which there was a good sampling of phasianoids, has particularly poor resolution and jackknife nodal support. 


\section{Relationships within major traditional clades}

The phylogenetic relationships within the Megapodiidae in the combined cladogram (Fig. 4) are largely congruent with those found by Birks and Edwards (2002) based on analyses of sequences from rhodopsin, a nuclear gene, and mtDNA, although they found that Macrocephalon was sister to Leipoa + Alectura and not to Megapodius (Fig. 3). Those for the cracids are congruent with those suggested by Pereira et al. (2002) (based on analyses of three nuclear genes: RAG-1, RAG-2, c-mos; an intron: Beta-fibrinogen; and seven mtDNA genes: 12S rDNA, CO1, CO2, CO3, CYT B, ND2/tRNA ${ }^{\text {Trp }}$ and ND5) in that the horned guan and chachalaca shift from the guans sensuDelacour and Amadon (1973) to a basal position within the curassow clade. However, the suggested relationships among the genera within these two subfamilies but do not mirror those suggested by Pereira et al. (2002). Relationships within the guineafowls differ from those suggested by Crowe (1978) in that Agelastes (and not Numida) is sister to Acryllium. Those for the four genera of New World quails studied here are completely congruent with those based on distance-based analyses of allozymes (Gutierrez et al., 1983). Those for the grouse are completely congruent with those found by Dimcheff et al. (2000) based on ND2 and 12S sequences and Drovetski (2002) based on the W-linked autosomal locus and CR sequences. Our results for the pheasants differ from those suggested in Fig. 2 in that Gallus spp. and the pavonines are place with other taxa. They agree in that they separate Lophophorus, Pucrasia and Ithaginis spp. (but not Tragopan spp.) from the gallopheasants and allies.

\section{Traditional groupings sundered (Fig. 4)}

The basal positioning (rather than sister relationship) of the megapodes relative to the cracids confirms the findings of Dimcheff et al. $(2000,2002)$ based on mitochondrial genes; Ericson et al. (2001) based on morphology and the nuclear c-myc gene; and Harshman's (1994) reanalysis of the Sibley and Ahlquist (1990) DNA-DNA hybridization data.

Perhaps the most striking cladistic result of this study is the decisive demonstration of the polyphyly of partridges (Perdicinae sensudel Hoyo et al., 1994). On reflection, however, this may not be surprising at all, as two of the key "characters" used to distinguish partridges from pheasants, the sexual monomorphism in the integument and the possession of less than 14 tail feathers (Johnsgard, 1973, 1986, 1988, 1999), have arisen (and appear to have been lost) many times in Fig. 10. Indeed, "the" grey partridge Perdix perdix (perdix is Greek for partridge) like the turkey, grouse and pheasants with which it groups is sexually dimorphic and has $>14$ tail feathers (Johnsgard, 1973, 1986, 1988, 
1999; del Hoyo et al., 1994). Pheasants (minus Gallus and pavonines), on the other hand, contraKimball et al. (1999), Lucchini and Randi (1999) and Bush and Strobeck (2003) form a monophyletic group in the combined cladogram (Fig. 4).

Another traditional taxon that fails to emerge as monophyletic is the francolins sensuHall (1963), Sibley and Monroe (1990), del Hoyo et al. (1994), and Dyke et al. (2003). At least two distantly related clades are recovered in Fig. 4, one comprising the "true" francolins (= relatives of $F$. francolinus) that includes Francolinus, Dendroperdix, Peliperdix and Scleroptila spp., the other comprising the partridge-like spurfowls (Pternistis spp.). Indeed, the phenetically aberrant African endemic Nahan's "francolin"Francolinus nahani is neither a francolin nor a spurfowl, but is sister to the stone partridge Ptilopachus petrosus (Cohen et al., in prep.). Ptilopachus spp., in turn, are sister to the New World quails (Fig. 4). This decisively confirms the speculations raised by Crowe and Crowe (1985), Milstein and Wolff (1987), Crowe et al. (1992) and Bloomer and Crowe (1998) that Francolinus sensu lato might not be monophyletic.

\section{Character evolution (Fig. 10)}

Spurs appear to have evolved at least twice within the Galliformes, once in the guineafowls (Agelastes + Acryllium) and a second time in the large clade spanning Tetraogallus through to Lophura spp. This is not surprising as spurs in guineafowls are not homologous to spurs in phasianines. In guineafowls, they develop directly from the tarsometatarsus, whereas in phasianines they develop initially on the hypotarsus and only secondarily attach to the tarsometatarsus (Holman, 1964). Within the large phasianine clade they appear to have been lost secondarily three times: in the argus pheasants (Argusianus + Rheinardia), grey partridge (Perdix) and grouse (Bonasa through to Tetrao). Davison (1985) has hypothesized that spurs are likely to have evolved first in monogamous species to favor competition between males for resources other than mates. However, research on free-ranging introduced ring-necked pheasants Phasianus colchicus by Goransson et al. (1990) suggests that harem females preferred males with longer spurs, but long spurs were not indicative of success in male-male contests. Therefore, although it is tempting to speculate that the loss of these in the abovementioned taxa is due to a lessening of importance of male-male competition for acquisition of female mates, the only empirical data available do not support such a hypothesis. Nevertheless, it would be instructive to conduct more detailed studies on these aspects of the mating system of vulturine guineafowl Acryllium vulturinum (spurred), as those of the helmeted guineafowl Numida meleagris (unspurred) are relatively well-understood (Little and Crowe, 2000). The spurless helmeted guineafowl is monogamous and female choice (during a period of several weeks of "dating" in the 
essential absence of male-male direct competition) plays a major part in the hen's selection of a sexual partner. Similarly, it would also be instructive to determine the relative importance of male-male competition and female choice in the apparently secondarily spurless argus pheasants, grey partridge and grouse vis-à-vis their spurred near relatives. Another possible explanation for the loss of spurs in grouse and Perdix is that they might be sites of heat loss and therefore a strong disadvantage during the boreal winter on the upland steppes of northern Eurasia.

A large number of tail feathers $(\geq 14)$ appears to have evolved at least three times: in the guineafowls (Guttera through to Acryllium); in the pavonines (Afropavo, Pavo, Polyplectron, being lost secondarily in the argus pheasants), and in a large clade including: the gray partridge (Perdix), turkey (Meleagris), grouse (Bonasa through to Tetrao) and pheasants (Ithaginis through to Lophura). Polygyny appears to have evolved at least twice: in the pavonines [being lost secondarily contra (Johnsgard, 1999) in Afropavo] and in the large clade spanning Perdix/Lophura, being lost secondarily in Perdix, the basal grouse (Bonasa through to Lagopus), the blood pheasant (Ithaginis), koklass (Pucrasia), tragopans (Tragopan), and eared pheasants (Crossoptilon).

Sexual dimorphism is perhaps the most complex of the "adaptive" characters explored here. It seems to have evolved many times: twice in the Cracidae in guans (Penelopina nigra) and in the currasows (Mitu + Pauxi + Crax); in the New World quails (Cyrtonyx through to Callipepla); and several times in the large clade spanning XenoperdixLophura.

Once again, as there is very little reliable information on aspects of courtship and mating in gamebirds in the wild (Ridley, 1987; Andersson, 1994; Johnsgard, 1999; Kimball et al., 2001), it is difficult to do more than speculate on the selective forces that influence these putatively adaptive characters. Ridley (1987) is the most recent review of this question. He hypothesized that polygyny was most likely to occur in forest-dwelling pheasants, as it is easier for males to guard females in thicker vegetation. However, these four adaptive characters do seem to have burgeoned in the relatively terminal phasianine clades from Argusianus onwards, with several genera, e.g., Meleagris, Pavo and several of the gallopheasants (especially polygynous species) possessing all four characters. This is consistent with the hypothesis that sexual selection involving improvement of both male competition and attractiveness to females has played a key role in the selection of these attributes (Davison, 1981, 1983, 1985). Nevertheless, as with spurs, a polygynous mating system is probably not an homologous condition, as it can be sequential, harembased or promiscuous (del Hoyo et al., 1994; Johnsgard, 1999). It also seems that these 
attributes may be lost secondarily, e.g., in grouse (Johnsgard, 1973) and gallopheasants (del Hoyo et al., 1994), should the selective advantage no longer apply.

\section{Biogeography of basal clades}

The present-day Southern Hemisphere distributions of members of the basal clades of the combined-data gamebird cladogram (Fig. 4) and their inferred dates of divergence (Table 5) indicate that, contrary to the views of some avian paleontologists (e.g., Feduccia, 1999), the duck-gamebird (Galloanserae) clade of modern birds diverged prior to the Cretaceous-Tertiary mass extinction event and that the cladogenesis of the basal gamebird clades (megapodes from Australasia, cracids from South America and guineafowls from Africa) took place in the Southern, not Northern, Hemisphere. Furthermore, if the Bayesian model-based estimates account more effectively for uncertainty in the estimation of branch lengths and heterogeneity in the rate of substitution among sites in different lineages (Pereira and Baker, 2006), the divergence of the guineafowls, New World quails (plus Ptilopachus spp.) and phasianids may also have been influenced by the break-up of Gondwana. These findings support those of Cracraft (2001), van Tuinen and Dyke (2004) and Clarke et al. (2005).

Nevertheless, if the split between guineafowls and New World quails occurred at more than $60 \mathrm{Ma}$, or even closer to the upper estimate for the $95 \%$ credible interval, a vicariance event between Africa and South America is not the most likely cause of this cladogenic event, as these two continents were already well separated by that time (Smith et al., 1994). In this case, the most plausible explanation for this event is dispersal from Africa to North America via Iberia, northern Britain, across what is now the Atlantic Ocean through Greenland. Pereira and Baker (2006) hypothesize a dispersal event for the guineafowls in the opposite direction because the New World quails are basal relative to guineafowls in their analyses. However, if the split between guineafowls and New World quails occurred at the upper limits indicated in Table 5, another possible, but perhaps less likely, means for the precursors of New World quails to have reached the neotropics is a dispersal event from Africa to South America. North-western Africa was still relatively close to north-eastern South America in the very Early Tertiary. North-western Africa was still relatively close to north-eastern South America in the very Early Tertiary, and the gap may have been traversed by even moderate dispersers (D. McCarthy, pers. comm.; Mueller et al., 1993).

The timing of an Africa-to-North America dispersal via Europe is in accord with the fossil record since the oldest unambiguous gamebird fossil Gallinuloides wyomingensis (Lower Eocene, $\sim 55 \mathrm{Ma}$ ) found in Wyoming (northern USA) has been placed 
cladistically at the base of a clade, including the guineafowls and remaining phasianoid gamebirds (Dyke, 2003; Lindow et al., in review), or even as sister to the phasianoids minus the guineafowls (Crowe and Short, 1992). Another fossil gallinuloid, Archaealectrornis sibleyi from the Middle to Upper Oligocene of Nebraska ( $\approx 35 \mathrm{Ma}$ ), shows even closer affinities to phasianines (Crowe and Short, 1992). There are also Eocene fossil gallinuloids from France (Mourer-Chauvire, 1988) and Denmark (Lindow et al., in review) and Oligocene fossils from France (Quercymegapodius spp.) that are most similar, at least morphometrically, to New World quails (Crowe and Short, 1992; but see Mourer-Chauvire, 1992 for another view).

This scenario is also in accord with Earth history, as the north Atlantic only started opening up along this route at about $55 \mathrm{Ma}$ (Smith et al., 1994) and Europe and North America were connected across the Greenland-Scotland ridge (McKenna, 1980, 1983). Furthermore, around this period, known as the "Early Eocene Climatic Optimum", the Earth was much warmer and covered with warm-temperate vegetation (Koch et al., 1992; Prothero, 1994; Blondel and Mourer-Chauvire, 1998; Scotese, 2001; Zachos et al., 2001) and much of Europe and North America (Wing et al., 2005) and Africa (Axelrod and Raven, 1978) was wetter along the suggested dispersal route. This is markedly different from the much more xeric present-day vegetation (e.g., a much wider Sahara desert) and would not have been a major barrier to traversal by largely terrestrial gamebirds. Finally, at $\pm 55 \mathrm{Ma}$ there were also major bouts of dispersal into North America by large terrestrial vertebrates (Koch et al., 1992; Gunnell, 1998; Bowen et al., 2002; Gingerich, 2003; Rose and Archibald, 2005) and plants (Wing et al., 2005) involving massive intraand intercontinental dispersals.

Moving to the other families, the guineafowls have an ancient African origin and are not the result of a mid-Miocene dispersal from Asia (Crowe, 1978) and the balance of the Asian phasianines are derived from a dispersal event from Africa. The converse seems to be the case for African spurfowls (Pternistis spp.) and scleroptilid francolins (Scleroptila spp.), which appear to have been the results of independent Asia-to-Africa dispersal events (Fig. 4; Table 5).

\section{Historical biogeography of other unexpected sisters (Fig. 4, Table 5)}

The sister relationship between Margaroperdix and Coturnix is easier to explain. First, there are also chick plumage characters that support such a phylogenetic relationship (Frost, 1975). Second, despite the fact that Africa and Madagascar were well separated at $120 \mathrm{Ma}$ (Smith et al., 1994; Sparks and Smith, 2004), there were mid-Tertiary steppingstones in the Mozambique channel (McCall, 1997) and it is not difficult to posit an aerial 
dispersal event at $\pm 18 \mathrm{Ma}$ (Table 5) given the ability of Coturnix spp. to traverse thousands of kilometers during their annual migrations (del Hoyo et al., 1994). The sister relationship between the forest-dwelling African (Afropavo) and Indian (Pavo) peafowl at 17-19 Ma appears to be the result of an Asia-to-Africa dispersal, and that of Udzungwa (Xenoperdix) and Hill (Arborophila) partridges at $\pm 39 \mathrm{Ma}$ (Table 5) may be due to an Africa-to-Asia dispersal through continuous or stepping-stone warm-temperate vegetation that expanded and contracted during the late Eocene or early Oligocene, with Xenoperdix being a relictual form now confined to three mountains in Tanzania (Dinesen et al., 1994; Fjeldså and Lovett, 1997; Bowie and Fjeldså, 2005). Such vegetation may have persisted or changed dynamically with fluctuating climate in corridors through the southern Middle East well into the Miocene (Axelrod and Raven, 1978; Dinesen et al., 1994; Scotese, 2001). Indeed, there is fossil evidence that a Pavo spp. persisted in Ethiopia as far back as the Early Pliocene (Louchart, 2003). The cladistic topology of Fig. 4 suggests that there was an initial dispersal by the common ancestor of Xenoperdix and Arborophila from Africa to Asia, and a subsequent dispersal of a pavonine from Asia back to Africa culminating in Afropavo. Other African forest birds (e.g., the white-crested tiger heron Tigriornis leucolophus, Nkulengu rail Himantornis hematopus, gray-throated rail Canirallus oculeus, Congo Bay owl Phodilus prigoginei, African green broadbill Pseudocalyptomena graueri, trogons Apaloderma spp., etc.) also have putative sister taxa in the Asiotropical Region (Olson, 1973).

Perhaps the easiest unexpected sister relationship to explain biogeographically is that between the bamboo "partridges" (Bambusicola spp.) and junglefowls (Gallus spp.) dating back $30 \mathrm{Ma}$ (Table 5). Members of these genera are, in fact, currently essentially parapatrically distributed in south-eastern Asia (del Hoyo et al., 1994).

\section{Conclusions}

If one returns to the aims of our research as outlined in the introductory section, the following conclusions can be made.

1

The monophyly of many of the currently recognized suprageneric galliform taxa Megapodiidae (megapodes), Cracidae (cracids), Numididae (guineafowls), Odontophoridae (New World quails), Tetraoninae (grouse), Pavoninae (peafowls sensu lato) and Phasianinae (pheasants minus Gallus) is confirmed decisively. 2

That of other taxa, e.g., partridges (Perdicinae) and francolins (Francolinus sensu 
lato), is rejected decisively.

3

New World quails are not phylogenetically relatively terminal galliforms related to Old World quails and partridges, but represent a much more basal divergence than traditional classifications have suggested.

4

New World quails are not basal relative to guineafowls as suggested by results of research based on DNA-DNA hybridization and analysis of mtDNA sequences, but are sister to the non-numidine phasianoids.

5

It is phylogenetically more sensible to analyze all character data partitions in combination rather than use a divisive "process"-partition approach as the different partitions in combination complement one another.

6

Discarding M/B and non-coding molecular characters results in massive losses of phylogenetic resolution and nodal support, particularly at deeper nodes within Galliformes.

7

Some "adaptive" characters (e.g., spurs and large number of tail feathers) have relatively uncomplicated evolutionary origins, whereas others (e.g., sexual dimorphism and polygamy) do not.

8

The early cladogenesis in the Galliformes pre-dates the Cretaceous-Tertiary mass extinction event and that basal divergences within the Order were influenced by the break-up of Gondwana.

9

The non-numidine phasianoids have a much more complex historical biogeography than previously thought, with connections between Africa and Europe, North America, South America and Asia.

\section{Classification}

A tentative revised classification of the Galliformes consistent with the cladistic structure in Fig. 4 is given below:

\section{Order GALLIFORMES}

Family Megapodiidae: scrubfowl (Megapodius), brush-turkeys (Alectura), mallefowl (Leipoa), maleo (Macrocephalon) 


\section{Family Cracidae}

Subfamily Cracinae: horned guan (Oreophasis), chachalacas (Ortalis), currasows (Crax, Nothocrax, Mitu, Pauxi)

Subfamily Penelopinae: remaining guans (Penelope, Penelopina, Chamaepetes, Pipile, Aburria)

Family Numididae: guineafowls (Agelastes, Acryllium, Guttera, Numida)

Family Odontophoridae: New World quails (Cyrtonyx, Oreortyx, Colinus, Callipepla) including the stone partridge Ptilopachus petrosus and Nahan's "francolin"Ptilopachus"Francolinus" nahani

\section{Family Phasianidae}

Subfamily Arborophilinae: Udzungwa and Rubeho forest partridges (Xenoperdix), hill partridges (Arborphila), crested wood-partridge (Rollulus)

Subfamily Coturnicinae: Old World quails (Coturnix, Excalfactoria), Madagascar partridge (Margaroperdix), snowcocks (Tetraogallus), partridges (Alectoris), sand partridge (Ammoperdix), bush-quails (Perdicula), spurfowls (Pternistis)

Subfamily Pavoninae: peafowls (Afropavo, Pavo), argus pheasants (Rheinardia, Argusianus), peacock pheasants (Polyplectron)

Subfamily Gallininae: bamboo-partridges (Bambusicola), junglefowls (Gallus), francolins (Francolinus, Dendroperdix, Peliperdix, Scleroptila)

Subfamily Meleagridinae: turkey (Meleagris), grey partridge (Perdix)

Subfamily Tetraoninae: grouse and capercaillie (Falcipennis, Dendragapus, Tetrao, Bonasa, Centrocercus), ptarmigans (Lagopus), prairie-chickens (Tympanuchus)

Subfamily Phasianinae: monals (Lophophorus), tragopans (Tragopan), pheasants (Phasianus, Chrysolophus, Lophura, Catreus, Crossoptilon)

\section{Future research}

Despite that fact that the cladogram for the combined analysis is well resolved, generally with strong nodal support, this situation lessens markedly within the "higher" phasianines from Argusianus onwards (Fig. 4). The monophyly of the pavonines to include the 
peacock pheasants (Polyplectron spp.) is clearly dependent on evidence provided by M/B characters. The sister relationship between the turkey (Meleagris) and grey partridge (Perdix) is also not recovered in the Bayesian analysis (Table 4) and is only recovered with low (58) jackknife support in the cladogram for the ND2 partition (Fig. 6). Finally, the monophyly of the pheasants minus Gallus spp. has yet to be established with nodal support using the normally accepted $\pm 37 \%$ of characters deleted per jackknife replicate. If this value is reduced to $20 \%$, the Phasianinae become monophyletic with a support value of 62 . Nevertheless, this calls for the exploration for more M/B and molecular evidence, and perhaps a reassessment of the former.

\section{References}

Andersson, M., 1994. Sexual Selection. Princeton University Press, .

Armstrong, M.H., Braun, E.L., Kimball, R.T., 2001. Phylogenetic utility of avian ovomucoid intron G: a comparison of nuclear and mitochondrial phylogenetics in Galliformes. Auk 118, 799-804.

Avise, J.C., Nelson, W.S., Sibley, C.G., 1994. Why one-kilobase sequences from mitochondrial DNA fail to solve the hoatzin phylogenetic enigma. Mol. Phylogenet. Evol. 3, $175-184$.

Axelrod, D.I., Raven, P.H., 1978. Late Cretaceous and Tertiary Vegetation History of Africa. In: Werger, M.J.A. (Ed.), Biogeography and Ecology of Southern Africa. Junk, , pp. $77-130$.

Birks, S.M., Edwards, S.V., 2002. A phylogeny of the megapodes (Aves: Megapodiidae) based on nuclear and mitochondrial DNA sequences. Mol. Phylogenet. Evol. 23, 408421.

-

Blondel, J., Mourer-Chauvire, C., 1998. Evolution and history of the western Palaearctic avifauna. Trends Ecol. Evol. 13, 488-492.

Bloomer, P., Crowe, T.M., 1998. Francolin phylogenetics: molecular, morpho-behavioral and combined evidence. Mol. Phylogenet. Evol. 8, 236-254.

Bowen, G.J., Clyde, W.C., Koch, P.L., Ting, S., Alroy, J., Tsubamoto, T., Wang, Y., Wang, Y., 2002. Mammalian dispersal at the Paleocene/Eocene boundary. Science, 295, $2062-2065$. 
Bowie, R.C.K., Fjeldså, J., 2005. Genetic and morphological evidence for two species in the Udzungwa forest partridge Xenoperdix udzungwensis. J. E. Afr. Nat. Hist. 94, 191201.

Bowie, R.C.K., Voelker, G., Fjeldså, J., Lens, L., Hackett, S., Crowe, T.M., 2005. Systematics of the olive thrush Turdus olivaceus species complex with reference to the taxonomic status of the endangered Taita thrush T. helleri. J. Avian Biol. 36, 391-404.

Brodkorb, P., 1964. Catalogue of fossil birds, part 2 (Anseriformes through Galliformes). Bull. Florida State Mus. Biol. Sci. 8, 195-335.

-

Brom, T., Dekker, R.W.R.J., 1992. Current studies on megapode phylogeny. Zool. Vehandlingen 278, 7-17.

Bull, J.J., Huelsenbeck, J.P., Cunningham, C.W., Swofford, D.L., Waddell, P.J., 1993. Partitioning and combining data in phylogenetic analysis. Syst. Biol. 42, 384-397.

-

Bush, K.L., Strobeck, C., 2003. Phylogenetic relationships of the Phasianidae reveals possible non-pheasant taxa. J. Hered. 94, 472-489.

-

Clarke, J.A., Tambussi, C.P., Noriega, J.I., Erickson, G.M., Ketcham, R.A., 2005.

Definitive fossil evidence for the extant avian radiation in the Cretaceous. Nature 433, 305-308.

Cox, W.A., Kimball, R.T., Braun, E.L., in press. Phylogenetic position of the New World quails: eight nuclear loci and three mitochondrial regions contradict morphology and the Sibley/Ahlquist tapestry. Auk, in press.

Cracraft, J., 1981. Toward a phylogenetic classification of the Recent birds of the world (class Aves). Auk, 98, 25-36.

-

Cracraft, J., 1983. Species concepts and speciation analysis. Curr. Ornithol. 1, 159-188.

Cracraft, J., 1988. The major clades of birds. In: Benton, M.J. (Ed.), The Phylogeny and Classification of Tetrapods. Clarendon Press, , pp. 1339-1361.

-

Cracraft, J., 2001. Avian evolution, Gondwana biogeography and the CretaceousTertiary mass extinction event. Proc. R. Soc. London B 268, 459-469.

Cracraft, J., Clarke, J., 2001. The basal clades of modern birds. In: Gauthier, J.A., Gall, L.F. (Eds.), Perspectives on the Origin and Early Evolution of Birds. Proceedings of the International Symposium in Honor of John H. Ostrom. Peabody Museum of Natural History, Yale University, , pp. 143-156. 
Cracraft, J., Helm-Bychowski, K., 1991. Parsimony and phylogenetic inference using DNA sequences: some methodological strategies. In: Miayamoto, M.M., Cracraft, J. (Eds.), Phylogenetic Analysis of DNA Sequences. Oxford University Press, , pp. 184220.

Crowe, T.M., 1978. The evolution of guineafowl: (Galliformes, Phasianidae, Numidinae): taxonomy, phylogeny, speciation and biogeography. Ann. S. Afr. Mus. 76, 43-136.

Crowe, T.M., 1988. Molecules vs. morphology in systematics: a non-controversy. Trans. R. Soc. S. Afr. 46, 317-334.

-

Crowe, T.M., Crowe, A.A., 1985. The genus Francolinus as a model for avian evolution and biogeography in Africa. In: Schuchmann, K.-L. (Ed.), Proceedings of the International Symposium on African Vertebrates. Museum Alexander Koenig, , pp. 207231.

-

Crowe, T.M., Short, L.L., 1992. A new gallinaceous bird from the Oligocene of Nebraska, with comments on the phylogenetic position of the Gallinuloididdae. Nat. Hist. Mus. Los Angeles Sci. Series 36, 179-185.

-

Crowe, T.M., Harley, E.H., Jakutowicz, M.B., Komen, J., Crowe, A.A., 1992.

Phylogenetic, taxonomic and biogeographical implications of genetic, morphological, and behavioral variations in francolins (Phasianidae: Francolinus). Auk 109, 24-42.

-

Davison, G.W.H., 1981. Sexual selection and the mating system of Argusianus argus (Aves: Phasianidae). Biol. J. Linn. Soc. 15, 91-104.

Davison, G.W.H., 1983. The eyes have it: ocelli in a rainforest pheasant. Anim. Behav. 31, 1037-1042.

-

Davison, G.W.H., 1985. Avian spurs. J. Zool. London 206, 353-366.

Delacour, J., Amadon, D., 1973. Curassows and Related Birds. American Museum of Natural History, .

Desjardins, P., Morais, R., 1990. Sequence and gene organization of the chicken mitochondrial genome. A novel gene order in higher vertebrates. J. Mol. Biol. 212, 599634.

-

Desjardins, P., Morais, R., 1991. Nucleotide sequence and evolution of coding and noncoding regions of a quail mitochondrial genome. J. Mol. Evol. 32, 153-161. 
Dimcheff, D.E., Drovetski, S.V., Krishnan, M., Mindell, D.P., 2000. Cospeciation and horizontal transmission of avian sarcoma and leucosis virus gag genes in galliform birds. J. Virol. 74, 3983-3995.

Dimcheff, D.E., Drovetski, S.V., Mindell, D.P., 2002. Phylogeny of Tetraoninae and other galliform birds using mitochondrial 12S and ND2 genes. Mol. Phylogenet. Evol. 24, 203-215.

Dinesen, L., Lehmberg, T.J., Svendsen, O., Hansen, T.A., Fjeldså, J., 1994. A new genus and species of perdicine bird from Tanzania: a relict form with Indo-Malayan affinities. Ibis 136, 3-11.

-

Drovetski, S.V., 2002. Molecular phylogeny of grouse: individual and combine performance of W-linked, autosomal, and mitochondrial loci. Syst. Biol. 51, 930-945.

-

Dyke, G.J., 2003. The phylogenetic position of Gallinuloides Eastman (Aves: Galliformes) from the Tertiary of North America. Zootaxa 199, 1-10.

Dyke, G.J., Gulas, B.E., Crowe, T.M., 2003. Suprageneric relationships of galliform birds (Aves, Galliformes): a cladistic analysis of morphological characters. Zool. J. Linn. Soc. 137, 227-244.

Edwards, S.V., Arctander, P., Wilson, A.C., 1991. Mitochondrial resolution of a deep branch in the genealogical tree for perching birds. Proc. R. Soc. London B 243, 99-107.

-

Ericson, P.G.P., 1996. The skeletal evidence for a sister-group relationship of anseriform and galliform birds - a critical evaluation. J. Avian Biol. 27, 195-202.

Ericson, P.G.P., Parsons, T.J., Johansson, U.S., 2001. Morphological and molecular support for non-monophyly of the Galloanserae. In: Gauthier, J.A., Gall, L.F. (Eds.), New Perspectives on the Origin and Evolution of Birds. Proceedings of the International Symposium in Honor of John H. Ostrom. Special Publication. Peabody Museum of Natural History, , pp. 157-168.

Farris, J.S., 1983. The logical basis of phylogenetic analysis. In: Platnick, N.I., Funk, V.A. (Eds.), Advances in Cladistics, Vol. 2. Proceedings of the Second Meeting of the Willi Hennig Society. Columbia University Press, , pp. 7-36.

Farris, J.S., Källersjö, M., Kluge, A.G., Bult, C., 1994. Testing significance of incongruence. Cladistics, 10, 315-319.

Farris, J.S., Albert, V.A., Källersjö, M., Lipscomb, D., Kluge, A., G., 1996. Parsimony jackknifing outperforms neighbor-joining. Cladistics, 12, 99-124.

-

Feduccia, A., 1999. The Origin and Evolution of Birds, 2nd edn. Yale University Press, . 
Fjeldså, J., Lovett, J.C., 1997. Geographical patterns of old and young species in African forest biota: the significance of specific montane areas as evolutionary centres. Biodiversity Conserv. 6, 325-346.

Freundenstein, J.V., Pickett, K.M., Simmons, M.P., Wenzel, J.W., 2003. From base pairs to bird songs: phylogenetic data in the age of genomics. Cladistics, 19, 333-347.

-

Frost, P.G.H., 1975. The systematic position of the Madagascan partridge Margaroperdix madagarensis (Scopoli). Bull. BOC 95, 64-68.

Fumihito, A., Miyake, T., Takada, M., Ohno, S., Kondo, N., 1995. The genetic link between the Chinese bamboo partridge (Bambusicola thoracica) and the chicken and junglefowls of the genus Gallus. Proc. Natl Acad. Sci. USA 92, 11053-11056.

Garcia-Moreno, J., Sorenson, M.D., Mindell, D.P., 2003. Congruent avian phylogenies inferred from mitochondrial and nuclear DNA sequences. J. Mol. Evol. 57, 27-37.

Gingerich, P.D., 2003. Mammalian responses to climatic change at the PaleoceneEocene boundary: polecat bench records in the northern Bighorn Basin, Wyoming. In: Wing. S.L. (Ed.), Causes and Consequences of Globally Warm Climates in the Early Paleogene. Special Paper 369. Geological Society of America, Boulder, CO, pp. 463478.

Goloboff, P.A., 1993. NONA, Version 2.0. Foundacion E. Instituto Miguel Lillo, . -

Goransson, G., von Schantz, T., Froberg, I., Helgee, A., Wittzell, H., 1990. Male characteristics, visibility and harem size in the pheasant, Phasianus colchicus. Anim. Behav. 40, 89-104.

Grau, E.T., Pereira, S.L., Silveira, L.F., Wajntal, A., 2003. Molecular markers contribute to a programme of the extinct-in-the-Alagoas Curassow Mitu mitu and the validity of the species. Bird Conserv. Int. 13, 115-126.

Groth, J.G., Barrowclough, G.J., 1999. Basal divergences in birds and the phylogenetic utility of the nuclear RAG-1 gene. Mol. Phylogenet. Evol. 12, 115-123.

-

Gulas-Wroblewski, B.E., Wroblewski, A.F.-J., 2003. A crown group galliform bird from the Middle Eocene Bridger Formation of Wyoming. Paleontology 46, 1269-1280.

Gunnell, G., 1998. Mammalian faunal composition and the Paleocene/Eocene Epoch/Series Boundary: evidence from the Northern Bighorn Basin, Wyoming. In: Berggren, W.A., Lucas, S., Aubry, M.-P. (Eds.), Late Paleocene-Early Eocene Climatic and Biotic Events in the Marine and Terrestrial Records. Columbia University Press, , Chapter 19. 
Gutierrez, R.J., Barrowclough, G.F., Groth, J.G., 2000. A classification of the grouse (Aves: Tetraoninae) based on mitochondrial DNA sequences. Wildl. Biol. 6, 205-211.

Gutierrez, R.J., Zink, R.M., Yang, S.Y., 1983. Genic variation, systematic, and biogeographic relationships of some galliform birds. Auk 100, 33-47.

Hall, B.P., 1963. The francolins, a study in speciation. Bull. Br. Mus. Nat, Hist. 10, 105204.

Harrison, G.L., McLenachan, P.A., Phillips, M.J., Slack, K.E., Cooper, A., Penny, D., 2004. Four new avian mitochondrial genomes help get to basic evolutionary questions in the Late Cretaceous. Mol. Biol. Evol. 21, 974-983.

Harshman, J., 1994. Reweaving the tapestry: what can we learn from Sibley and Ahlquist (1990)? Auk 111, 377-388.

Helm-Bychowski, K.M., Wilson, A.C., 1986. Rates of nuclear DNA evolution in pheasant-like birds: evidence from restriction maps. Proc. Natl Acad. Sci. USA 83, 688692.

Ho, C.Y.-K., Prager, E.M., Wilson, A.C., Osuga, D.T., Feeney, R.E., 1976. Penguin evolution: protein comparisons demonstrate phylogenetic relationship to flying birds. $J$. Mol. Evol. 8, 1976.

Hockey, P.A.R., Dean, W.R.J., Ryan, P.G. (Eds.), 2005. Roberts—Birds of Southern Africa, VIIth Edn. The Trustees of the John Voelcker Bird Book Fund, .

Holman, J.A., 1964. Osteology of gallinaceous birds. Q. J. Flor. Acad. Sci. 27, 230-252.

del Hoyo, J., Elliott, A., Sargatal, J. (Eds.), 1994. Handbook of the Birds of the World, Vol. 2. New World Vultures to Guineafowls. Lynx Edicions, Barcelona.

Hudson, G.E., Lanzillotti, P.J., Edwards, G.D., 1959. Muscles of the pelvic limb in galliform limb in galliform birds. Am. Midl. Nat. 61, 1-67.

-

Hudson, G.E., Lanzillotti, P.J., 1964. Muscles of the pectoral limb in galliform birds. Am. Midl. Nat. 71, 1-113.

Hudson, G.E., Parker, R.A., Van den Berge, Lanzillotti, P.J., 1966. A numerical analysis of the modifications of the appendicular muscles in the various genera of gallinaceous birds. Am. Midl. Nat. 76, 1-73.

Irwin, D.M., Kocher, T.D., Wilson, A.C., 1991. Evolution of the cytochrome $b$ gene in mammals. J. Mol. Evol. 32, 128-144. 
Johnsgard, P.A., 1973. The Grouse and Quails of North America. University of Nebraska Press, .

Johnsgard, P.A., 1986. The Pheasants of the World. Oxford University Press, .

Johnsgard, P.A., 1988. The Quails, Partridges, and Francolins of the World. Oxford University Press.

Johnsgard, P.A., 1999. The Pheasants of the World, 2nd edn. Smithsonian Institution Press.

-

Johnson, K.P., Sorenson, M.D., 1998. Comparing molecular evolution in two mitochondrial protein coding genes (cytochrome $b$ and ND2) in the dabbling ducks (Tribe: Anatini). Mol. Phylogenet. Evol. 10, 82-94.

Jolles, J., Schoentgen, F., Jolles, P., Wilson, A.C., 1976. Amino acid sequence and immunological properties of chachalaca egg white lysozymes. J. Mol. Evol. 8, 59-78.

Jolles, J., Ibrahimi, I.M., Prager, E.M., Schoentgen, F., Jolles, P., Wilson, A.C., 1979. Amino acid sequence of pheasant lysozyme. Evolutionary change affecting processing of pre-lysozyme. Biochemistry 18, 2744-2752.

Jones, D.N., Dekker, R.W.R., Roselaar, C.S., 1995. The Megapodes: Megapodiidae. Oxford University Press, .

-

Joseph, L., Slikas, B., Rankin-Baransky, K., Bazartseren, B., Alpers, D., Gilbert, A.E., 1999. DNA evidence concerning the identities of Crax viridirostris Sclater, 1875 and C. estudilloi Allen, 1977. Ornitol. Neotrop. 10, 129-144.

Källersjö, M., Farris, J.S., Chase, M.W., Bremer, B., Fay, M.F., Humphries, C.J., Petersen, G., Seberg, O., Bremer, K., 1998. Simultaneous parsimony jackknife analysis of 2538 rbcL DNA sequences reveals support for major clades of green plants, land plants, seed plants and flowering plants. Plant Syst. Evol. 213, 259-287.

Kearney, M., Clarke, J., 2003. Problems due to missing data in phylogenetic analyses including fossils: a critical review. J. Vertebr. Paleontol. 23, 263-274.

Kimball, R.T., Braun, E.L., Ligon, J.D., 1997. Resolution of the phylogenetic position of the Congo peafowl, Afropavo congensis: a biogeographic and evolutionary enigma. Proc. R. Soc. London B Biol. Sci. 264, 1517-1523.

Kimball, R.T., Braun, E.L., Ligon, J.D., Lucchini, V., Randi, E., 2001. A molecular phylogeny of the peacock-pheasants (Galliformes: Polyplectron spp.) indicates loss and reduction of ornamental traits and display behaviours. Biol. J. Linn. Soc. London 73, $187-198$. 
Kimball, R.C., Braun, E.L., Zwartjies, P.W., Crowe, T.M., Ligon, J.D., 1999. A molecular phylogeny of the pheasants and partridges suggests that these lineages are not monophyletic. Mol. Phylogenet. Evol. 11, 38-54.

Kluge, A.G., 1989. A concern for evidence and a phylogenetic hypothesis of relationships among Epicrates (Boidae, Serpentes). Syst. Zool. 38, 7-25.

-

Kluge, A.G., 2004. On total evidence: for the record. Cladistics 9, 205-207.

Kluge, A.G., Wolf, A.J., 1993. Cladistics: what's in a word? Cladistics 9, 183-189.

-

Koch, P.L., Zachos, J.C., Gingerich, P.D., 1992. Correlation between isotope records in marine and continental carbon reservoirs near the Paleocene/Eocene boundary. Nature 358, 319-322.

Kornegay, J.R., Kocher, T.D., Williams, L.A., Wilson, A.C., 1993. Pathways of lysozyme evolution inferred from sequences of cytochrome $b$ in birds. J. Mol. Evol. 37, 367-379.

Lanyon, S.M., 1993. Phylogenetic frameworks: towards a firmer foundation for the comparative approach. Biol. J. Linn. Soc. 49, 45-61.

Laskowski, M., Fitch, W.M., 1989. Evolution of Ovomucoids in Birds. In: Fernhilm, B., Bremer, K.K., Jornvall, H. (Eds.), The Hierarchy of Life: Molecules and Morphology in Phylogenetic Analyses. Excerpta Medica, , pp. 371-387.

Lecointre, G., Deleporte, P., 2005. Total evidence requires exclusion of phylogenetically misleading data. Zool. Scr. 34, 101-117.

Lindow, B.E.K., Dyke, G.J., Crowe, T.M., in review. A small galliform bird from the Lower Eocene of Denmark: the phylogenetic position of Gallinuloides. Bull. Dan. Geol. Soc., in review.

Little, R.M., Crowe, T.M., 2000. Gamebirds of Southern Africa. Struik, .

-

Liu, H.T., Hu, Y.H., Wang, C.T., Lin, L.Y., 1996. Sequences and comparisons of duck mitochondrial DNA control regions. Comp. Biochem. Physiol. B, Biochem. Mol. Biol. 115, 209-214.

$\bullet$

Louchart, A., 2003. A true peafowl in Africa. S. Afr. J. Sci. 99, 368-371.

-

Lucchini, V., Randi, E., 1999. Molecular evolution of the mtDNA control-region in galliform birds. In: Adams, N.J., Slotow, R.H. (Eds.), Proceedings of the 22 International Ornithological Congress, Durban. Birdlife South Africa, , pp. 732-739. 
Lucchini, V., Hoglund, J., Klaus, S., Swenson, J., Randi, E., 2001. Historical biogeography and a mitochondrial DNA phylogeny of grouse and ptarmigan. Mol. Phylogenet. Evol. 20, 149-162.

Mayr, E., 1942. Systematics and the Origin of Species. Columbia University Press, .

-

Mayr, G., 2005. The Paleogene fossil record of birds in Europe. Biol. Rev. 80, 1-28.

Mayr, G., Clarke, J., 2003. The deep divergence of modern birds: a phylogenetic analysis of morphological characters. Cladistics 19, 527-533.

-

Mayr, G., Weidig, I., 2004. The Early Eocene bird Gallinuloides wyomingensis - a stem group representative of Galliformes. Acta Palaeontol. Pol. 49, 211-217.

McCall, R.A., 1997. Implications of recent geological investigations of the Mozambique Channel for the mammalian colonization of Madagascar. Proc. R. Soc. London B, 164, 663-665.

McKenna, M.C., 1980. Eocene paleolatitutde, climate and mammals of Ellesmere Island. Palaeogeog. Palaeoclim. Palaeoecol. 30, 349-362.

-

McKenna, M.C., 1983. Cenozoic paleogeography of north atlantic land bridges. In: Bott, M.P.H., Saxov, S., Talwani, M., Theide, J. (Eds.), NATO Conference Series IV, Marine Sciences 8, pp. 351-400.

-

Meece, J.K., Reynolds, C.E., Stockwell, P.J., Christensen, J.E., Reed, K.D., 2005. Identification of mosquito blood meal source by terminal restriction fragment length polymorphism (T-RFLP) profile analysis of the cytochrome $b$ gene. J. Med. Entomol. 42, $657-667$.

Milstein, P.L.S., Wolff, S.W., 1987. The oversimplification of our 'francolins'. S. Afr. J. Wildl. Res. Suppl. 1, 58-65.

Mindell, D.P., Sorenson, M.D., Huddleston, C.J., Miranda, H.C. Jr, Knight, A., Sawchuck, S.J., Yuri, T., 1997. Phylogenetic relationships among and within select avian orders based on mitochondrial DNA. In: Mindell, D.P. (Ed.), Avian Molecular Evolution and Systematics. Academic Press, , pp. 213-247.

Mindell, D.P., Sorenson, M.D., Dimcheff, D.E., 1998. Multiple independent origins of mitochondrial gene order in birds. Proc. Natl Acad. Sci. USA 95, 10693-10697.

Miyamoto, M., Fitch, W.M., 1995. Testing species phylogenies and phylogenetic methods with congruence. Syst. Biol. 44, 64-76. 
Mourer-Chauvire, C., 1988. Le gisement du Bretou (Phosphorites du Quercy, Tarn-etGaronne, France) et sa faune de vertebras de l'Eocene superieur. Oiseaux. Palaeontogr. (A), 205, 29-50.

Mourer-Chauvire, C., 1992. The Galliformes (Aves) of the Phosphorites du Quercy (France): systematics and biogeography. Nat. Hist. Mus. Los Angeles Sci. Series 36, 6795.

Mueller, R.D., Roest, W.R., Royer, J.-Y., Gahagan, L.M., Sclater, J.G., 1993. A Digital Age Map of the Ocean Floor. SIO Reference Series 93-30, Scripps Institution of Oceanography, La Jolla, CA.

-

Nishibori, M., Hayashi, T., Tsudzuki, M., Yamamoto, Y., Yasue, H., 2001. Complete sequence of the Japanese quail (Coturnix japonica) mitochondrial genome and its genetic relationship with related species. Anim. Genet. 32, 380-385.

-

Nishibori, M., Hayashi, T., Yasue, H., 2004. Complete nucleotide sequence of Numida meleagris (Helmeted Guineafowl) mitochondrial genome. J. Poult. Sci. 41, 259-268.

Nishibori, M., Tsudzuki, M., Hayashi, T., Yamamoto, Y., Yasue, H., 2002. Complete nucleotide sequence of the Coturnix chinensis (blue-breasted quail) mitochondrial genome and a phylogenetic analysis with related species. J. Hered. 93, 439-444.

Nishibori, M., Shimogiri, T., Hayashi, T., Yasue, H., in press. Molecular evidence for hybridization of species in the genus Gallus except for Gallus varius. Anim. Genet. 36, $367-375$.

Nixon, K.C., 1992. Winclada, Version 0.9.99m24 (BETA). Published by the author, (available at http://www.cladistics.org ).

-

Nixon, K.C., Carpenter, J.M., 1996. On simultaneous analysis. Cladistics 12, 221-241.

Nixon, K.C., Wheeler, Q.D., 1990. An amplification of the phylogenetic species concept. Cladistics 6, 211-233.

-

Olson, S.L., 1973. A classification of the Rallidae. Wilson Bull. 85, 381-416.

Olson, S.L., 1980. The significance of the distribution of the Megapodiidae. Emu 80, 2124.

Pereira, S.L., Baker, A.J., 2004. Vicariant speciation of curassows (Aves: Cracidae): a hypothesis based on mitochondrial DNA phylogeny. Auk 121, 682-694. 
Pereira, S.L., Baker, A.J., 2006. A molecular timescale for galliform birds accounting for uncertainty in time estimates and heterogeneity of rates of DNA substitutions across lineages and sites. Mol. Phylogenet. Evol. 38, 499-509.

Pereira, S.L., Baker, A.J., Wajntal, A., 2002. Combined nuclear and mitochondrial DNA sequences resolve generic relationships within the Cracidae (Galliformes, Aves). Syst. Biol. 51, 946-958.

Pereira, S.L., Grau, E.T., Wajntal, A., 2004. Molecular architecture and rates of DNA substitutions of the mitochondrial control region of cracid birds. Genome 47, 535-545.

-

Posada, D., Crandall, K.A., 1998. Modeltest: testing the model of DNA substitution. Bioinfomatics 14, 817-818.

Prager, E.M., Wilson, A.C., 1976. Congruency of phylogenies derived from different proteins. A molecular analysis of the phylogenetic position of cracid birds. J. Mol. Evol. 9, 45-57.

Prothero, D.R., 1994. The Eocene-Oligocene Transition: Paradise Lost. Columbia University Press.

-

Rambaut, A., Charleston, M., 1999. Tree-Edit. Available at http://0evolve.zoo.ox.ac.uk.innopac.up.ac.za:80/.

Randi, E., 1996. A mitochondrial cytochrome $b$ phylogeny of the Alectoris partridges. Mol. Phylogenet. Evol. 6, 214-227.

-

Randi, E., Fusco, G., Lorenzini, R., Crowe, T.M., 1991. Phylogenetic relationships in the Phasianoidea. Biochem. Syst. Ecol. 19, 213-221.

-

Randi, E., Lucchini, V., Armijo-Prewitt, T., Kimball, R.T., Braun, E.L., Ligon, J.D., 2000. Mitochondrial DNA phylogeny and speciation in the tragopans. Auk 117, 10031015.

Randi, E., Lucchini, V., Hennache, A., Kimball, R.T., Braun, E.L., Ligon, J.D., 2001. Evolution of the mitochondrial DNA control region and cytochrome $b$ genes and the inference of phylogenetic relationships in the avian genus Lophura (Galliformes). Mol. Phylogenet. Evol. 19, 187-201.

Ridley, M.W., 1987. Relevance of social organization to conservation in the pheasant family. In: Savage, C., Ridley, M.W., (Eds.), Pheasants in Asia. Proceedings of The 2nd International Symposium on Pheasants in Asia. World Pheasant Association, , pp. 115118. 
Ronquist, F., Huelsenbeck, J.P., 2003. MrBayes 3: Bayesian phylogenetic inference under mixed models. Bioinformatics 19, 1572-1574.

-

Rose, K.D., Archibald, D. (Eds.), 2005. The Rise of Placental Mammals: Origins and Relationships of the Major Extant Clades. The Johns Hopkins University Press, .

-

Sanderson, M.J., 1997. A nonparametric approach to estimating divergence times in the absence of rate constancy. Mol. Biol. Evol. 14, 1218-1231.

Scotese, C.R., 2001. Atlas of Earth History, Vol. 1 Paleogeography. PALEOMAP Project, .

-

Scotland, R.W., Olmstead, R.G., Bennett, J.R., 2003. Phylogeny reconstruction: the role of morphology. Syst. Biol. 52, 539-548.

Sheldon, F.H., Bledsoe, A.H., 1993. Avian molecular systematics, 1970s to 1990s. Ann. Rev. Ecol. Syst. 24, 243-278.

Shibusawa, M., Nishibori, M., Nishida-Umehara, C., Tsudzuki, M., Masabanda, J., Griffin, D.K., Matsuda, Y., 2004. Karyotypic evolution in the Galliformes: an examination of the process of karyotypic evolution by comparison of the molecular cytogenetic findings with the molecular phylogeny. Cytogenet. Genome Res. 106, 111119.

Sibley, C.G., 1960. The electrophoretic patterns of avian egg-white proteins as taxonomic characters. Ibis 102, 215-284.

Sibley, C.G., 1994. On the phylogeny and classification of living birds. J. Avian Biol. 25, 87-92.

-

Sibley, C.G., Ahlquist, J.E., 1972. A comparative study of egg-white proteins of nonpasserine birds. Bull. Peabody Mus. Nat. Hist. 39, 1-276.

Sibley, C.G., Ahlquist, J.E., 1985. The relationships of some groups of African birds, based on comparisons of the genetic material DNA. In: Schuchmann, K.-L. (Ed.), Proceedings of the International Symposium on African Vertebrates. Museum Alexander Koenig, , pp. 115-161.

Sibley, C.G., Ahlquist, J.E., 1990. Phylogeny and Classification of Birds. Yale University Press, .

Sibley, C.G., Monroe, B.L., 1990. The Distribution and Taxonomy of the Birds of the World. Yale University Press. 
Smith, A.G., Smith, D.G., Funnell, B.N., 1994. Atlas of Mesozoic and Cenozoic Coastlines. Cambridge University Press.

Sorenson, M.D., Ast, J.C., Dimcheff, D.E., Yuri, T., Mindell, D.P., 1999. Primers for a PCR-based approach to mitochondrial genome sequencing in birds and other vertebrates. Mol. Phylogenet. Evol. 12, 1.5-1.114.

-

Sorenson, M.D., Oneal, E., Garcia-Moreno, J., Mindell, D.P., 2003. More taxa, more characters: the hoatzin problem is still unresolved. Mol. Biol. Evol. 20, 1484-1498.

Sparks, J.S., Smith, W.L., 2004. Phylogeny and biogeography of cichlid fishes (Teleostei: Perciformes: Cichlidae). Cladistics 20, 501-517.

Swofford, D.L., 1991. When are phylogeny estimates from molecular and morphological data incongruent?. In: Miyamoto, M.M., Cracraft, J. (Eds.), Phylogenetic Analysis of DNA Sequences. Oxford University Press, , pp. 295-333.

Swofford, D.L., Olsen, G.L., Waddell, P.J., Hillis, D.M., 1996. Phylogenetic inference. In: Hillis, D.M., Morowitz, C., Mable, B.K. (Eds.), Molecular Systematics, 2nd edn. Sinauer, , pp. 407-514.

-

Thompson, J.D., Jeanmougin, F., Gouy, M., Higgins, D.G., Gibson, T.J., 1997. Multiple sequence alignment with Clustal X. Trends Biochem. Sci. 23, 403-405.

Thorne, J.L., Kishino, H., 2002. Divergence time and evolutionary rate estimation with multilocus data. Syst. Biol. 51, 689-702.

Tordoff, H.B., Macdonald, J.R., 1957. A new bird (family Cracidae) from the early Oligocene of South Dakota. Auk 74, 174-184.

-

Valverde, J.R., Marco, R., Garesse, R., 1994. A conserved heptamer motif for ribosomal RNA transcription termination in animal mitochondria. Proc. Natl Acad. Sci. USA 91, 5368-5371.

-

Van Tuinen, M., Dyke, G.J., 2004. Calibration of galliform molecular clocks using multiple fossils and genetic partitions. Mol. Phylogenet. Evol. 30, 74-86.

Verheyen, R., 1956. Contribution a l'anatomie et a la systematique des Galliformes. Bull. Inst. Roy. Sci. Nat. Belg. 32, 1-24.

-

Vuilleumier, F., 1965. Relationships and evolution within the Cracidae (Aves:

Galliformes). Bull. Mus. Comp. Zool., Harvard 134, 1-27. 
Wada, Y., Yamada, Y., Nishibori, M., Yasue, H., 2004. Complete nucleotide sequence of mitochondrial genome in silkie fowl (Gallus gallus var. domesticus). J. Poult. Sci. 41, 76-82.

Wetmore, A., 1960. A classification for the birds of the world. Smithson Miscellaneous Collection 139, 1-37.

-

Wiens, J.J., 2003. Incomplete taxa, incomplete characters, and phylogenetics accuracy: is there a missing data problem? J. Vertebr. Paleontol. 23, 297-310.

Wiens, J.J., 2005. Can incomplete taxa rescue phylogenetic analyses from long-branch attraction? Syst. Biol. 54, 731-742.

Wikstrom, N., Savolainen, V., Chase, M.W., 2001. Evolution of the Angiosperms: calibrating the family tree. Proc. $R$. Soc. London B. 268, 2211-2220.

-

Wing, S.L., Harrington, G.J., Smith, F.A., Block, J.I., Boyer, D.M., Freeman, K.H., 2005. Transient floral change and rapid global warming at the Paleocene-Eocene boundary. Science 310, 993-996.

-

Yang, Z., 1997. PAML: a program package for phylogenetic analysis by maximum likelihood. Comput. Appl. Biosci. 13, 555-556.

Zachos, J., Pagani, M., Sloan, L., Thomas, E., Billups, K., 2001. Trends, rhythms, and aberrations in global climate 65 Ma to present. Science 292, 686-693.

-

Zhan, X., Zhang, Z., 2003. Phylogenetic relationships of monal pheasants Lophophorus inferred from sequences of mitochondrial cytochrome $b$ gene. Zool. Res. 24, 337-342. 


\section{Appendices}

\section{Appendix 1}

Outgroup and gamebird taxa investigated in this research. Those taxa marked with * were used in the Bayesian and molecular clock divergence analyses

\begin{tabular}{|c|c|}
\hline \multicolumn{2}{|l|}{ Anseriformes } \\
\hline Anseranas semipalmata & magpie goose \\
\hline Chauna torquata & southern screamer* \\
\hline Anhima cornuta & horned screamer* \\
\hline \multicolumn{2}{|l|}{ Galliformes } \\
\hline \multicolumn{2}{|l|}{ Megapodiidae } \\
\hline Megapodius freycinet & dusky scrubfowl \\
\hline Megapodius reinwardt & orange-footed scrubfowl \\
\hline Megapodius eremita & Melanesian scrubfowl* \\
\hline Leipoa ocellata & malleefow $1^{*}$ \\
\hline Macrocephalon maleo & maleo \\
\hline Alectura lathami & Australian brush-turkey* \\
\hline \multicolumn{2}{|l|}{ Cracidae } \\
\hline Ortalis vetula & plain chachalaca \\
\hline Ortalis canicollis & chaco chachalaca* \\
\hline Oreophasis derbianus & horned guan* \\
\hline Penelope obscura & dusky-legged guan* \\
\hline Penelope superciliaris & rusty-margined guan \\
\hline Penelope ochrogaster & chestnut-bellied guan \\
\hline Penelope purpurascens & crested guan \\
\hline Penelopina nigra & highland guan* \\
\hline Pipile jacutinga & black-fronted piping-guan* \\
\hline Pipile pipile & Trinidad piping-guan \\
\hline Pipile cumanensis & blue-throated piping-guan \\
\hline Pipile cujubi & red-throated piping-guan \\
\hline Aburria aburri & wattled guan* \\
\hline
\end{tabular}




\begin{tabular}{|c|c|}
\hline Crax rubra & great curassow* \\
\hline Crax alector & black curassow \\
\hline Crax alberti & blue-bellied curassow \\
\hline Crax daubentoni & yellow-knobbed curassow \\
\hline Crax blumenbachii & red-billed curassow* \\
\hline Crax globulosa & wattled curassow \\
\hline Crax fasciolata & bare-faced curassow \\
\hline Mitu tuberosa & razor-billed curassow* \\
\hline Mitu mitu & Alagoas curassow \\
\hline Mitu salvini & Salvin's curassow \\
\hline Mitu tomentosa & crestless curassow* \\
\hline Chamaepetes goudotii & sickle-winged guan* \\
\hline Pauxi pauxi & northern helmeted curassow* \\
\hline Pauxi unicornis & southern helmeted curassow \\
\hline Nothocrax urumutum & nocturnal curassow* \\
\hline \multicolumn{2}{|l|}{ Numididae } \\
\hline Guttera pucherani & crested guineafowl \\
\hline Guttera plumifera & plumed guineafowl \\
\hline Numida meleagris & helmeted guineafowl* \\
\hline Agelastes meleagrides & white-breasted guineafowl \\
\hline Acryllium vulturinum & vulturine guineafowl* \\
\hline \multicolumn{2}{|l|}{ Odontophoridae } \\
\hline Cyrtonyx montezumae & Montezuma quail* \\
\hline Oreortyx pictus & mountain quail* \\
\hline Callipepla squamata & scaled quail \\
\hline Callipepla gambelii & Gambel's quail* \\
\hline Callipepla californica & California quail \\
\hline Callipepla douglasii & elegant quail \\
\hline Colinus virginianus & northern bobwhite quail* \\
\hline \multicolumn{2}{|l|}{ Tetraonidae } \\
\hline Bonasa umbellus & ruffed grouse* \\
\hline
\end{tabular}




\begin{tabular}{|c|c|}
\hline Bonasa bonasia & hazel grouse \\
\hline Bonasa sewerzowi & Severtsov's grouse \\
\hline Dendragapus obscurus & blue grouse \\
\hline Falcipennis canadensis & spruce grouse* \\
\hline Falcipennis falcipennis & Siberian grouse \\
\hline Tetrao urogallus & western capercaillie \\
\hline Tetrao tetrix & eurasian black grouse* \\
\hline Tetrao parvirostris & black-billed capercaillie \\
\hline Tetrao mlokosiewiczi & Caucasian black grouse \\
\hline Centrocercus urophasianus & sage grouse \\
\hline Lagopus leucurus & white-tailed ptarmigan \\
\hline Lagopus mutus & rock ptarmigan* \\
\hline Lagopus lagopus & willow ptarmigan* \\
\hline Tympanuchus pallidicinctus & lesser prairie-chicken \\
\hline Tympanuchus cupido & greater prairie-chicken \\
\hline Tympanuchus phasianellus & sharp-tailed grouse* \\
\hline \multicolumn{2}{|l|}{ Meleagrididae } \\
\hline Meleagris gallopavo & wild turkey* \\
\hline \multicolumn{2}{|l|}{ Phasianidae } \\
\hline \multicolumn{2}{|l|}{ Phasianinae } \\
\hline Ithaginis cruentus & blood pheasant* \\
\hline Lophophorus impejanus & Himalayan monal* \\
\hline Lophophorus ilhuysii & Chinese monal \\
\hline Lophophorus sclateri & Sclater's monal \\
\hline Pucrasia macrolopha & koklass pheasant* \\
\hline Tragopan temminckii & Temminck's tragopan* \\
\hline Tragopan satyra & satyr tragopan \\
\hline Tragopan blythii & Blyth's tragopan \\
\hline Tragopan caboti & Cabot's tragopan \\
\hline Syrmaticus humiae & Hume's pheasant \\
\hline Syrmaticus reevesii & Reeves's pheasant \\
\hline
\end{tabular}




\begin{tabular}{|l|l|}
\hline Syrmaticus ellioti & Elliot's pheasant* \\
\hline Syrmaticus mikado & Mikado pheasant \\
\hline Phasianus versicolor & green pheasant \\
\hline Phasianus colchicus & ring-necked pheasant* \\
\hline Chrysolophus pictus & golden pheasant* \\
\hline Chrysolophus amherstiae & Lady Amherst's pheasant \\
\hline Lophura nycthemera & silver pheasant* \\
\hline Lophura diardi & Siamese fireback \\
\hline Lophura swinhoii & Swinhoe's pheasant \\
\hline Lophura edwardsi & Edwards's pheasant \\
\hline Lophura bulweri & Bulwer's pheasant \\
\hline Lophura erythropthalma & crestless fireback pheasant \\
\hline Lophura ignita & crested fireback pheasant \\
\hline Lophura inornata & Salvadori's pheasant \\
\hline Lophura leucomelanos & Kalij pheasant \\
\hline Catreus wallichii & cheer pheasant* \\
\hline Crossoptilon crossoptilon & white eared-pheasant* \\
\hline Crossoptilon auritum & blue eared-pheasant \\
\hline Crossoptilon mantchuricum & brown eared-pheasant \\
\hline Gallus gallus & red junglefowl* \\
\hline Gallus varius & green junglefowl \\
\hline Gallus sonnerati & grey junglefowl \\
\hline Gallus lafayettei & Ceylon junglefowl \\
\hline Polyplectron biclacaratum & grey peacock-pheasant* \\
\hline Polyplectron emphanum & Palawan peacock-pheasant* \\
\hline Polyplectron chalcurum & bronze-tailed peacock-pheasant \\
\hline Polyplectron germaini & Germain's peacock-pheasant \\
\hline Polyplectron inopinatum & mountain peacock-pheasant \\
\hline Polyplectron malacense & Malaysian peacock-pheasant \\
\hline Argusianus argus & crested argus \\
\hline Rheinardia ocellata & \\
\hline
\end{tabular}




\begin{tabular}{|l|l|}
\hline Afropavo congensis & Congo peafowl* \\
\hline Pavo cristatus & Indian peafowl* \\
\hline Pavo muticus & green peafowl* \\
\hline Perdicinae & \multicolumn{2}{|l|}{} \\
\hline Ptilopachus"Francolinus"nahani & Nahan's francolin* \\
\hline Ptilopachus petrosus & stone partridge* \\
\hline Xenoperdix udzungwensis & Udzungwa forest-partridge* \\
\hline Rollulus rouloul & crested wood-partridge \\
\hline Arborophila javanica & chestnut-bellied hill-partridge* \\
\hline Arborophila torqueola & common hill-partridge \\
\hline Perdix perdix & grey partridge* \\
\hline Bambusicola thoracica & Chinese bamboo-partridge* \\
\hline Bambusicola fytchii & mountain bamboo-partridge \\
\hline Dendroperdix sephaena & South Africa crested francolin* \\
\hline Dendroperdix sephaena & Kenya crested francolin \\
\hline Francolinus francolinus & black francolin \\
\hline Francolinus pondicerianus & grey francolin \\
\hline Francolinus gularis & swamp francolin \\
\hline Francolinus lathami & Latham's francolin \\
\hline Peliperdix coqui & coqui francolin \\
\hline Scleroptila levaillantii & red-winged francolin* \\
\hline Scleroptila finschi & Finsch's francolin \\
\hline Scleroptila levaillantoides & Orange River francolin* \\
\hline Scleroptila africanus & grey-winged francolin* \\
\hline Scleroptila shelleyi South Africa & Shelley's francolin* \\
\hline Scleroptila shelleyi Kenya & Shelley's francolin \\
\hline Tetraogallus himalayensis & Himalayan snowcock \\
\hline Tetraogallus tibetanus & Tibetan snowcock \\
\hline Tetraogallus altaicus & Atai snowcock \\
\hline Alectoris melanocephala & \\
\hline Alectoris barbara & \\
\hline
\end{tabular}




\begin{tabular}{|c|c|}
\hline Alectoris rufa & red-legged partridge* \\
\hline Alectoris graeca & rock partridge \\
\hline Alectoris chukar & chukar partridge* \\
\hline Alectoris philbyi & Philby's partridge \\
\hline Alectoris magna & Przevalski's partridge \\
\hline Margaroperdix madagarensis & Madagascar partridge* \\
\hline Coturnix japonica & Japanese quail* \\
\hline Coturnix coturnix & common quail \\
\hline Excalfactoria chinensis & Asian blue quail \\
\hline Ammoperdix heyi & sand partridge \\
\hline Perdicula asiatica & jungle bush-quail \\
\hline Pternistis hartlaubi & Hartlaub's spurfowl \\
\hline Pternistis erckelii & Erckel's spurfowl \\
\hline Pternistis castaneicollis & chestnut-naped spurfowl \\
\hline Pternistis bicalcaratus & double-spurred spurfowl \\
\hline Pternistis griseostriatus & grey-striped spurfowl \\
\hline Pternistis leucoscepus & yellow-necked spurfowl \\
\hline Pternistis squamatus & scaly spurfowl* \\
\hline Pternistis swainsonii & Swainson's spurfowl \\
\hline Pternistis afer South Africa & red-necked spurfowl \\
\hline Pternistis afer Angola & red-necked spurfowl \\
\hline Pternistis capensis & Cape spurfowl* \\
\hline Pternistis adspersus & red-billed spurfowl \\
\hline Pternistis hildebrandti & Hildebrandt's spurfowl \\
\hline Pternistis natalensis & Natal spurfowl* \\
\hline
\end{tabular}




\section{Appendix 2}

Sources and amounts of DNA sequence data for mitochondrial cytochrome $b$, NADH dehydrogenase subunit 2 (ND2), control region, 12S rDNA (12S) and nuclear ovomucoid G sequences (+= sequence, $=$ no sequence). Superscripts on GenBank numbers refer to publications listed below

\begin{tabular}{|c|c|c|c|c|c|c|c|c|}
\hline Taxon & $\begin{array}{l}\text { No. } \\
\text { bases }\end{array}$ & $\begin{array}{c}\text { CYT B } \\
\text { GenBank no. }\end{array}$ & & $\begin{array}{c}\text { No. } \\
\text { bases }\end{array}$ & $\begin{array}{c}\text { ND2 } \\
\text { GenBank no. }\end{array}$ & $\begin{array}{c}\text { control* } \\
\text { region } \\
n=1030 \\
\text { bases }\end{array}$ & $\begin{array}{c}\text { 12S } n=731 \\
\text { bases }\end{array}$ & $\begin{array}{c}\text { Ovomucoid } \\
\text { G } \dagger \\
n=492 \\
\text { bases }\end{array}$ \\
\hline $\begin{array}{l}\text { Anseranas } \\
\text { semipalmata }\end{array}$ & 1143 & NC00593335 & & 1041 & $\mathrm{NC} 005933^{35}$ & - & $\mathrm{NC} 005933^{35}$ & - \\
\hline Chauna torquata & 1143 & AY14073621 & AY274030 & 999 & AY $140738^{21}$ & - & AY $140700^{21}$ & - \\
\hline Anhima cornuta & 1002 & AY14073521 & & 999 & AY $140737^{21}$ & - & AY $140699^{21}$ & - \\
\hline $\begin{array}{l}\text { Megapodius } \\
\text { freycinet }\end{array}$ & 659 & AM236880 & & 1041 & AF394631 & DQ834464 & - & - \\
\hline $\begin{array}{l}\text { Megapodius } \\
\text { reinwardt }\end{array}$ & 1002 & AF16546521 & & 1041 & AY $140739^{21}$ & - & AF $165441^{21}$ & - \\
\hline $\begin{array}{l}\text { Megapodius } \\
\text { eremita }\end{array}$ & 1143 & AF0820659 & & 1041 & AY $274052^{25}$ & - & AY $274005^{25}$ & - \\
\hline Leipoa ocellata & 1143 & AM236879 & & 1041 & AF394619 & - & AF222586 & - \\
\hline $\begin{array}{l}\text { Macrocephalon } \\
\text { maleo }\end{array}$ & 1143 & AM236881 & & 1041 & AF394621 & - & - & - \\
\hline Alectura lathami & 1143 & $\mathrm{NC} 007227^{\mathrm{u}}$ & & 1041 & AY274051 & DQ834465 & AY274004 & DQ832069 \\
\hline Ortalis vetula & 1143 & L083841 & & 1041 & AF394614 & - & - & AF $170974^{14}$ \\
\hline Ortalis canicollis & 1002 & AF16547221 & & 999 & AY $140746^{21}$ & AF $165436^{29}$ & AF $165448^{21}$ & - \\
\hline
\end{tabular}




\begin{tabular}{|c|c|c|c|c|c|c|c|c|}
\hline $\begin{array}{l}\text { Oreophasis } \\
\text { derbianus }\end{array}$ & 1002 & AF16547121 & & 1041 & AY $140745^{21}$ & AF $165435^{29}$ & AF $165447^{21}$ & - \\
\hline Penelope obscura & 1002 & AF16547421 & & 999 & AY $140742^{21}$ & AF $165432^{29}$ & AF $165450^{21}$ & - \\
\hline $\begin{array}{l}\text { Penelope } \\
\text { superciliaris }\end{array}$ & 699 & AY36710229 & & 441 & AY367096 29 & AY $145313^{29}$ & - & - \\
\hline $\begin{array}{l}\text { Penelope } \\
\text { ochrogaster }\end{array}$ & 699 & AY36710129 & & 441 & AY367O95 29 & AY $145311^{29}$ & - & - \\
\hline $\begin{array}{l}\text { Penelope } \\
\text { purpurascens }\end{array}$ & 792 & AY354491 & AY367103 & 441 & AY367097 29 & AY $145312^{29}$ & - & - \\
\hline Penelopina nigra & 1002 & AF16547521 & & 999 & AY $140743^{21}$ & AF $165433^{29}$ & AF $165451^{21}$ & - \\
\hline Pipile jacutinga & 1002 & AF16547621 & & 999 & AY $140744^{21}$ & AF165431 & AF $165452^{21}$ & - \\
\hline Pipile pipile & 699 & AY36710629 & & 441 & AY367100 29 & AY $145320^{29}$ & - & - \\
\hline Pipile cumanensis & 699 & AY36710529 & & 441 & AY367099 29 & AY $145319^{29}$ & - & - \\
\hline Pipile cujubi & 699 & AY36710429 & & 441 & AY367098 29 & AY $145314^{29}$ & - & - \\
\hline Aburria aburria & 1002 & AF16546621 & & 997 & AY $140740^{21}$ & AF $165430^{29}$ & AF $165442^{21}$ & - \\
\hline \multirow{2}{*}{ Crax rubra } & \multirow{2}{*}{1143} & AY14192528 & AY274029 & 1041 & AY274050 25 & AY $145307^{29}$ & AY274003 & - \\
\hline & & AF106502 10 & & & & & - & \\
\hline Crax alector & 1143 & AY14192128 & AF $106507^{10}$ & 999 & AY $141931^{28}$ & AY $145315^{29}$ & - & - \\
\hline Crax alberti & 1014 & AY14192028 & AF $106498^{10}$ & 999 & AY $141930^{28}$ & AY $145304^{29}$ & - & - \\
\hline Crax daubentoni & 1014 & AY 14192228 & AF $106500^{10}$ & 999 & AY $141932^{28}$ & AY $145305^{29}$ & - & - \\
\hline $\begin{array}{l}\text { Crax } \\
\text { blumenbachii }\end{array}$ & 1002 & AF16546821 & & 999 & AY $140747^{21}$ & AF $165438^{29}$ & AF $165444^{21}$ & - \\
\hline Crax globulosa & 1014 & AY14192428 & AF $106506^{10}$ & 999 & AY $141934^{28}$ & AY $145316^{29}$ & - & - \\
\hline Crax fasciolata & 1014 & AY354487 & AY $141923^{28}$ & 999 & AY $141933^{28}$ & AY $145306^{29}$ & - & - \\
\hline
\end{tabular}




\begin{tabular}{|c|c|c|c|c|c|c|c|c|}
\hline Mitu tuberosa & 1002 & AF16546921 & & 999 & AY $140748^{21}$ & AF $165437^{29}$ & AF $165445^{21}$ & - \\
\hline Mitu mitu & 1002 & AY14192628 & AY098552 & 999 & AY $141936^{28}$ & AY $145308^{29}$ & - & - \\
\hline Mitu salvani & 1002 & AY14192728 & & 999 & AY $141937^{28}$ & AY $145309^{29}$ & - & - \\
\hline Mitu tomentosa & 1002 & AY14192828 & AY098556 & 999 & AY $141938^{28}$ & AY $145310^{29}$ & - & - \\
\hline $\begin{array}{l}\text { Chamaepetes } \\
\text { goudotii }\end{array}$ & 1002 & AF 16546721 & & 997 & AY $140741^{21}$ & AF $165434^{29}$ & AF $165443^{21}$ & - \\
\hline Pauxi pauxi & 1143 & AF06819011 & & 999 & AY $140750^{21}$ & AF $165439^{29}$ & AF $165449^{21}$ & AF $170973^{14}$ \\
\hline Pauxi unicornis & 1002 & AY14192928 & & 999 & AY $141939^{28}$ & AY $145317^{29}$ & - & - \\
\hline $\begin{array}{l}\text { Nothocrax } \\
\text { urumutum }\end{array}$ & 1002 & AF16547021 & & 999 & AY $140749^{21}$ & AF $165440^{29}$ & AF $165446^{21}$ & - \\
\hline Guttera pucherani & 1143 & AM236882 & & & - & - & - & - \\
\hline Guttera plumifera & 1143 & AM236883 & & & - & - & - & - \\
\hline Numida meleagris & 1143 & L083831 & & 1041 & $\mathrm{NC} 006382^{27}$ & DQ834466 & AF222587 & AF $170975^{14}$ \\
\hline $\begin{array}{l}\text { Agelastes } \\
\text { meleagrides }\end{array}$ & 1143 & AM236884 & & & - & - & - & - \\
\hline $\begin{array}{l}\text { Acryllium } \\
\text { vulturinum }\end{array}$ & 1143 & AF53674223 & & 1041 & AF536745 & - & AF536739 & DQ832070 \\
\hline $\begin{array}{l}\text { Cyrtonyx } \\
\text { montezumae }\end{array}$ & 1143 & AF06819211 & & 303 & AF028779 & DQ834467 & - & AF $170976^{14}$ \\
\hline Oreortyx pictus & 1143 & AF25286014 & & 301 & $\mathrm{AF} 028782^{\mathrm{u}}$ & DQ834468 & - & AF $170977^{14}$ \\
\hline $\begin{array}{l}\text { Colinus } \\
\text { virginianus }\end{array}$ & 912 & $\mathrm{AF} 028775^{\mathrm{u}}$ & $\mathrm{AF} 028774^{\mathrm{u}}$ & 1041 & AF222545 & DQ834469 & AF222576 & - \\
\hline $\begin{array}{l}\text { Callipepla } \\
\text { douglasii }\end{array}$ & 734 & $\mathrm{AF} 028750^{\mathrm{u}}$ & $\mathrm{AF} 028751^{\mathrm{u}}$ & 303 & $\mathrm{AF} 028752^{\mathrm{u}}$ & DQ834470 & - & - \\
\hline Callipepla & 1012 & $\mathrm{AF} 028753^{\mathrm{u}}$ & $\mathrm{AF} 028754^{\mathrm{u}}$ & 303 & $\mathrm{AF} 028758^{\mathrm{u}}$ & DQ834471 & - & - \\
\hline
\end{tabular}




\begin{tabular}{|c|c|c|c|c|c|c|c|c|}
\hline squamata & & $\mathrm{AF} 028756^{\mathrm{u}}$ & & & & & - & \\
\hline $\begin{array}{l}\text { Callipepla } \\
\text { gambelii }\end{array}$ & 1143 & L083821 & & 297 & $\mathrm{AF} 028761^{\mathrm{u}}$ & DQ834472 & - & - \\
\hline $\begin{array}{l}\text { Callipepla } \\
\text { californica }\end{array}$ & 1143 & AB12013130 & & 303 & $\mathrm{AF} 028773^{\mathrm{u}}$ & DQ834473 & - & - \\
\hline $\begin{array}{l}\text { Ptilopachus } \\
\text { nahani }\end{array}$ & 1142 & AM236885 & & 1039 & DQ768288 & - & - & DQ832071 \\
\hline $\begin{array}{l}\text { Ptilopachus } \\
\text { petrosus }\end{array}$ & 1132 & AM236886 & & 1039 & DQ768289 & - & - & DQ832072 \\
\hline $\begin{array}{l}\text { Xenoperdix } \\
\text { udzungwensis }\end{array}$ & 1143 & AM236887 & & 1041 & DG09380034 & DQ834474 & DQ832096 & DQ832073 \\
\hline Rollulus rouloul & 1140 & AM236888 & & & - & - & - & - \\
\hline $\begin{array}{l}\text { Arborophila } \\
\text { javanica }\end{array}$ & 1143 & AM236889 & & 1041 & DG09380434 & - & DQ832097 & DQ832074 \\
\hline $\begin{array}{l}\text { Arborophila } \\
\text { torqueola }\end{array}$ & 1143 & AM23688t & & & - & DQ834475 & - & - \\
\hline Bonasa umbellus & 1141 & AY50967732 & AF230167 & 1041 & AF222541 ${ }^{12}$ & DQ834476 & $\mathrm{U} 83740^{6}$ & - \\
\hline Bonasa bonasia & 609 & AF23016516 & & 1041 & AF222539 & DQ834477 & AF222571 12 & - \\
\hline Bonasa sewerzowi & 612 & AF23016616 & & 1041 & AF222540 12 & - & AF222572 & - \\
\hline $\begin{array}{l}\text { Dendragapus } \\
\text { obscurus }\end{array}$ & 609 & AF23017816 & & 1041 & AF $222549^{12}$ & - & AF222580 12 & - \\
\hline $\begin{array}{l}\text { Falcipennis } \\
\text { canadensis }\end{array}$ & 1143 & AF $170992^{\mathrm{u}}$ & & 1041 & AF222548 & DQ834478 & AF $222577^{12}$ & AF $170986^{14}$ \\
\hline $\begin{array}{l}\text { Falcipennis } \\
\text { falcipennis }\end{array}$ & 609 & AF23016916 & & 1041 & AF $222547^{12}$ & - & AF222578 & - \\
\hline Centrocercus & 609 & AF23017716 & & 1041 & AF222542 & - & AF222573 ${ }^{12}$ & - \\
\hline
\end{tabular}




\begin{tabular}{|c|c|c|c|c|c|c|c|}
\hline urophasianus & & & & & & & \\
\hline Tetrao tetrix & 609 & AF23017416 & 1041 & AF222564 ${ }^{12}$ & DQ834479 & AF222593 ${ }^{12}$ & - \\
\hline Tetrao urogallus & 1143 & AB12013230 & 1041 & AF222565 & DQ834480 & AF222594 & - \\
\hline $\begin{array}{l}\text { Tetrao } \\
\text { parvirostris }\end{array}$ & 549 & AF23017516 & 1041 & AF $222563^{12}$ & - & AF222592 & - \\
\hline $\begin{array}{l}\text { Tetrao } \\
\text { mlokosiewiczi }\end{array}$ & 561 & AF23017316 & 1041 & AF222562 & - & AF222591 ${ }^{19}$ & - \\
\hline Lagopus leucurus & 609 & AF23017116 & 1041 & AF222553 & - & AF222584 & - \\
\hline Lagopus mutus & 1033 & AY $156346^{\mathrm{u}}$ & 1041 & AF222554 & DQ834481 & AF222585 & - \\
\hline Lagopus lagopus & 609 & AF23017016 & 1041 & AF222552 12 & DQ834482 & AF222583 & - \\
\hline $\begin{array}{l}\text { Tympanuchus } \\
\text { pallidicinctus }\end{array}$ & 609 & AF23018016 & 1041 & AF222568 & - & AF222597 12 & - \\
\hline $\begin{array}{l}\text { Tympanuchus } \\
\text { cupido }\end{array}$ & 609 & AF23017916 & 1041 & AF $222567^{12}$ & - & AF $222596^{12}$ & - \\
\hline $\begin{array}{l}\text { Tympanuchus } \\
\text { phasianellus }\end{array}$ & 1143 & AF06819111 & 1041 & AF222569 & DQ834483 & AF222598 & AF $170985^{14}$ \\
\hline Perdix perdix & 1143 & AF02879111 & 1041 & AF222560 & DQ834484 & AF222590 & AF $170982^{14}$ \\
\hline $\begin{array}{l}\text { Meleagris } \\
\text { gallopavo }\end{array}$ & 1143 & L083811 & 1041 & AF222556 & DQ834485 & $\mathrm{U}^{2} 3741^{6}$ & AF $170984^{14}$ \\
\hline $\begin{array}{l}\text { Lophophorus } \\
\text { impejanus }\end{array}$ & 1143 & AF02879611 & 1041 & DQ768259 & DQ834486 & DQ832098 & DQ832075 \\
\hline $\begin{array}{l}\text { Lophophorus } \\
\text { ilhuysii }\end{array}$ & 1143 & AY26530926 & & - & - & AY447956 & - \\
\hline $\begin{array}{l}\text { Lophophorus } \\
\text { sclateri }\end{array}$ & 1143 & AY26531026 & & - & - & - & - \\
\hline
\end{tabular}




\begin{tabular}{|c|c|c|c|c|c|c|c|}
\hline Ithaginis cruentus & 1143 & AF06819311 & 1040 & DQ768258 & DQ834487 & - & DQ832076 \\
\hline $\begin{array}{l}\text { Tragopan } \\
\text { temminckii }\end{array}$ & 1143 & AF22983813 & 1041 & AF222566 & DQ834488 & AF222595 & - \\
\hline Tragopan satyra & 1143 & AF53455522 & & - & DQ834489 & - & - \\
\hline Tragopan blythii & 1143 & AF20072213 & 1041 & DQ768272 & - & - & - \\
\hline Tragopan caboti & 1143 & AF53455422 & & - & - & $\mathrm{AB} 004240^{\mathrm{u}}$ & - \\
\hline $\begin{array}{l}\text { Pucrasia } \\
\text { macrolopha }\end{array}$ & 1143 & AF02880011 & 1041 & DQ768269 & DQ834490 & - & AF 17098314 \\
\hline $\begin{array}{l}\text { Syrmaticus } \\
\text { humiae }\end{array}$ & 1143 & AF534706 & 1038 & DQ768293 & DQ834491 & DQ832099 & DQ832077 \\
\hline $\begin{array}{l}\text { Syrmaticus } \\
\text { reevesii }\end{array}$ & 1143 & AY368059 & 1041 & DQ768271 & DQ834492 & - & - \\
\hline Syrmaticus ellioti & 1143 & AY368061 & 1041 & DQ768270 & DQ834493 & DQ832100 & DQ832078 \\
\hline $\begin{array}{l}\text { Syrmaticus } \\
\text { mikado }\end{array}$ & 1143 & AY368056 & 1032 & DQ768294 & DQ834494 & DQ832101 & DQ832079 \\
\hline $\begin{array}{l}\text { Phasianus } \\
\text { colchicus }\end{array}$ & 1143 & AY368060 & 1041 & AF $222561^{12}$ & DQ834495 & U83742 6 & - \\
\hline $\begin{array}{l}\text { Phasianus } \\
\text { versicolor }\end{array}$ & 1143 & AY368058 & & - & DQ834496 & - & - \\
\hline $\begin{array}{l}\text { Chrysolophus } \\
\text { pictus }\end{array}$ & 1143 & AF02879311 & 1041 & DQ768255 & DQ834497 & & - \\
\hline $\begin{array}{l}\text { Chrysolophus } \\
\text { amherstiae }\end{array}$ & 1143 & AB12013030 & 1031 & DQ768277 & - & DQ832102 & DQ832080 \\
\hline $\begin{array}{l}\text { Lophura } \\
\text { nycthemera }\end{array}$ & 1143 & L083801 & 1041 & DQ768261 & DQ834498 & - & - \\
\hline Lophura diardi & 1143 & AF02879711 & & - & - & - & - \\
\hline
\end{tabular}




\begin{tabular}{|c|c|c|c|c|c|c|c|}
\hline Lophura swinhoii & 1143 & AF53455822 & 1041 & DQ768262 & - & - & - \\
\hline Lophura edwardsi & 1143 & AF53455722 & & - & - & - & - \\
\hline Lophura bulweri & 1143 & AF31463718 & & - & - & - & - \\
\hline $\begin{array}{l}\text { Lophura } \\
\text { erythropthalma }\end{array}$ & 1143 & AF31463918 & & - & - & - & - \\
\hline Lophura ignita & 1143 & AF31464118 & & - & - & - & - \\
\hline Lophura inornata & 1143 & AF31464218 & 1041 & DQ768260 & - & - & - \\
\hline $\begin{array}{l}\text { Lophura } \\
\text { leucomelana }\end{array}$ & 1143 & AF31464318 & & - & - & - & - \\
\hline Catreus wallichii & 1143 & AF02879211 & 1041 & DQ768254 & DQ834499 & - & AF17098014 \\
\hline $\begin{array}{l}\text { Crossoptilon } \\
\text { crossoptilon }\end{array}$ & 1143 & AF02879411 & 1041 & DQ768256 & DQ834500 & - & AF17098114 \\
\hline $\begin{array}{l}\text { Crossoptilon } \\
\text { auritum }\end{array}$ & 1143 & AF53455222 & & - & DQ834501 & - & - \\
\hline $\begin{array}{l}\text { Crossoptilon } \\
\text { mantchuricum }\end{array}$ & 1143 & AF53455322 & & - & DQ834502 & - & - \\
\hline $\begin{array}{l}\text { Polyplectron } \\
\text { bicalcaratum }\end{array}$ & 1143 & AF53456422 & 1041 & DQ768263 & DQ834503 & - & AF33195915 \\
\hline $\begin{array}{l}\text { Polyplectron } \\
\text { emphanum }\end{array}$ & 1143 & AF33006215 & 1041 & DQ768265 & DQ834504 & - & AF33195515 \\
\hline $\begin{array}{l}\text { Polyplectron } \\
\text { chalcurum }\end{array}$ & 1143 & AF33006115 & 1041 & DQ768264 & - & - & AF33195615 \\
\hline $\begin{array}{l}\text { Polyplectron } \\
\text { germaini }\end{array}$ & 1143 & AF33006315 & 1041 & DQ768266 & - & - & AF33196015 \\
\hline $\begin{array}{l}\text { Polyplectron } \\
\text { inopinatum }\end{array}$ & 1143 & AF33006415 & 1041 & DQ768267 & - & - & AF33195815 \\
\hline
\end{tabular}




\begin{tabular}{|c|c|c|c|c|c|c|c|}
\hline $\begin{array}{l}\text { Polyplectron } \\
\text { malacense }\end{array}$ & 1143 & AF33006515 & 1041 & DQ768268 & - & - & AF33195715 \\
\hline Argusianus argus & 1143 & AF0137615 & & - & DQ834505 & - & AF331954 \\
\hline $\begin{array}{l}\text { Rheinardia } \\
\text { ocellata }\end{array}$ & 1143 & AF33006015 & & - & DQ834506 & - & - \\
\hline $\begin{array}{l}\text { Afropavo } \\
\text { congensis }\end{array}$ & 1143 & AF0137605 & 1041 & DQ768253 & DQ834507 & - & AF17099114 \\
\hline Pavo cristatus & 1143 & L083791 & 1041 & AF394612 & DQ834508 & AY722396 & AF $170990^{14}$ \\
\hline Pavo muticus & 1143 & AF0137635 & & - & DQ834509 & - & AF $170989^{14}$ \\
\hline Gallus gallus & 1143 & L083761 & 1041 & $\mathrm{AB} 086102^{31}$ & DQ834510 & $\mathrm{NC} 001323^{2}$ & AF $170979^{14}$ \\
\hline Gallus varius & 1143 & $\mathrm{AB} 044988^{\mathrm{u}}$ & 1041 & AF222551 12 & - & - & - \\
\hline Gallus sonneratii & 1143 & $\mathrm{AB} 044989^{\mathrm{u}}$ & & & DQ834511 & AP006746 & - \\
\hline Gallus lafayettei & 1143 & $\mathrm{AB} 044990^{\mathrm{u}}$ & & - & DQ834512 & AP003325 33 & - \\
\hline $\begin{array}{l}\text { Bambusicola } \\
\text { thoracica }\end{array}$ & 1143 & AF02879011 & 1041 & AF $222538^{12}$ & DQ834513 & AF $222570^{12}$ & AF $170978^{14}$ \\
\hline $\begin{array}{l}\text { Bambusicola } \\
\text { fytchii }\end{array}$ & 1143 & AM236891 & & - & - & - & - \\
\hline $\begin{array}{l}\text { Francolinus } \\
\text { francolinus }\end{array}$ & 1143 & AF0137625 & & - & DQ834514 & & - \\
\hline $\begin{array}{l}\text { Francolinus } \\
\text { pondicerianus }\end{array}$ & 660 & U906487 & 1032 & DQ768279 & - & DQ832103 & DQ832081 \\
\hline $\begin{array}{l}\text { Francolinus } \\
\text { gularis }\end{array}$ & 660 & U906497 & & - & - & - & - \\
\hline $\begin{array}{l}\text { Francolinus } \\
\text { lathami }\end{array}$ & 1143 & AM236893 & 1041 & DQ768257 & - & - & DQ832082 \\
\hline
\end{tabular}




\begin{tabular}{|c|c|c|c|c|c|c|c|c|}
\hline $\begin{array}{l}\text { Dendroperdix } \\
\text { sephaena }\end{array}$ & 1143 & U906477 & AM236894 & 1040 & DQ768274 & DQ834515 & DQ832104 & DQ832083 \\
\hline Peliperdix coqui & 785 & U906467 & AM236895 & 1040 & DQ768278 & - & DQ832105 & DQ832084 \\
\hline $\begin{array}{l}\text { Scleroptila } \\
\text { levaillantii }\end{array}$ & 1143 & U906427 & AM236913 & 1039 & DQ768291 & DQ834516 & DQ832106 & DQ832085 \\
\hline Scleroptila finschi & 1095 & U906437 & AM236896 & 701 & DQ768290 & - & - & - \\
\hline $\begin{array}{l}\text { Scleroptila } \\
\text { africanus }\end{array}$ & 1143 & U906297 & AM236897 & 1041 & AF22255012 & DQ834517 & AF222581 12 & DQ832086 \\
\hline $\begin{array}{l}\text { Scleroptila } \\
\text { shelleyi }\end{array}$ & 1143 & U906457 & AM236898 & 684 & DQ768295 & DQ834518 & DQ832107 & DQ832087 \\
\hline $\begin{array}{l}\text { Scleroptila } \\
\text { levaillantoides }\end{array}$ & 1143 & U906447 & AM236900 & 1038 & DQ768292 & DQ834519 & DQ832108 & - \\
\hline $\begin{array}{l}\text { Tetraogallus } \\
\text { himalayensis }\end{array}$ & 1143 & AY678108 & & & - & DQ834520 & - & - \\
\hline $\begin{array}{l}\text { Tetraogallus } \\
\text { tibetanus }\end{array}$ & 535 & AY563133 & & & - & - & - & - \\
\hline \begin{tabular}{|l} 
Tetraogallus \\
altaicus
\end{tabular} & 535 & AY $563127^{\mathrm{u}}$ & & & - & - & - & - \\
\hline $\begin{array}{l}\text { Alectoris } \\
\text { melanocephala }\end{array}$ & 1143 & Z487734 & & & - & DQ834521 & - & - \\
\hline Alectoris barbara & 1143 & Z487714 & & & - & DQ834522 & - & - \\
\hline Alectoris rufa & 1143 & Z487754 & & & - & DQ834523 & - & AF $170988^{14}$ \\
\hline Alectoris graeca & 1143 & Z487724 & & & - & DQ834524 & - & - \\
\hline Alectoris chukar & 1143 & L083781 & & 1040 & DQ768273 & DQ834525 & - & AF 17098714 \\
\hline Alectoris philbyi & 1143 & Z487744 & & & - & DQ834526 & - & - \\
\hline
\end{tabular}




\begin{tabular}{|c|c|c|c|c|c|c|c|c|}
\hline Alectoris magna & 1143 & Z487764 & & & - & DQ834527 & - & - \\
\hline $\begin{array}{l}\text { Margaroperdix } \\
\text { madagarensis }\end{array}$ & 660 & U906407 & & & - & DQ834528 & - & - \\
\hline Coturnix coturnix & 1143 & L083771 & & 1041 & X57246 36 & DQ834529 & $X 57245^{36}$ & - \\
\hline Coturnix japonica & 1143 & NC00340817 & & 1041 & NC003408 ${ }^{17}$ & - & NC003408 ${ }^{17}$ & - \\
\hline $\begin{array}{l}\text { Excalfactoria } \\
\text { chinensis }\end{array}$ & 1143 & $\mathrm{NC} 00457520$ & & 1041 & $\mathrm{NC} 004575^{20}$ & - & $\mathrm{AB} 073301^{20}$ & - \\
\hline Ammoperdix heyi & 622 & AM236901 & & & - & - & - & - \\
\hline Perdicula asiatica & 1143 & AY390778 & AM236902 & & - & DQ834530 & - & - \\
\hline $\begin{array}{l}\text { Pternistis } \\
\text { hartlaubi }\end{array}$ & 660 & U906397 & & & - & - & - & - \\
\hline Pternistis erckelii & 660 & U906387 & & & - & - & - & - \\
\hline $\begin{array}{l}\text { Pternistis } \\
\text { castaneicollis }\end{array}$ & 1143 & AM236903 & & & - & - & - & - \\
\hline $\begin{array}{l}\text { Pternistis } \\
\text { bicalcaratus }\end{array}$ & 660 & U906377 & & & - & - & - & - \\
\hline $\begin{array}{l}\text { Pternistis } \\
\text { squamatus }\end{array}$ & 1136 & U906367 & AM236904 & 1039 & DQ768286 & DQ834531 & DQ832109 & DQ832088 \\
\hline $\begin{array}{l}\text { Pternistis } \\
\text { griseostriatus }\end{array}$ & 763 & AM236905 & & 1040 & DQ768284 & - & - & DQ832089 \\
\hline $\begin{array}{l}\text { Pternistis } \\
\text { leucoscepus }\end{array}$ & 1138 & AM236906 & & 1034 & DQ768283 & - & - & DQ832090 \\
\hline $\begin{array}{l}\text { Pternistis } \\
\text { Swainsonii }\end{array}$ & 1142 & U906347 & AM236907 & 1039 & DQ768287 & DQ834532 & DQ832110 & DQ832091 \\
\hline Pternistis afer & 1143 & U906357 & AM236908 & 1038 & DQ768281 & DQ834533 & DQ832111 & DQ832092 \\
\hline
\end{tabular}




\begin{tabular}{|c|c|c|c|c|c|c|c|c|}
\hline $\begin{array}{l}\text { Pternistis } \\
\text { capensis }\end{array}$ & 1143 & U906327 & AM236909 & 1038 & DQ768282 & DQ834534 & DQ832112 & DQ832093 \\
\hline $\begin{array}{l}\text { Pternistis } \\
\text { adspersus }\end{array}$ & 789 & U906337 & AM236910 & 1039 & DQ768276 & DQ834535 & DQ832113 & DQ832095 \\
\hline $\begin{array}{l}\text { ernistis } \\
\text { ldebrandti }\end{array}$ & 617 & U906317 & & & - & - & - & - \\
\hline $\begin{array}{l}\text { Pternistis } \\
\text { natalensis }\end{array}$ & 1143 & U906307 & AM236911 & 1039 & DQ768285 & DQ834536 & - & DQ832094 \\
\hline \multicolumn{9}{|c|}{$\begin{array}{l}\text { *+ from Lucchini and Randi (1999) and Pereira et al. (2004) corresponding to bases } 13-169 \text { and } 377-1033 \text { in Gallus gallus } \\
\text { from Desjardins and Morais (1990) GenBank no. NC001323; †corresponding to bases } 1228-1296 \text { in Gallus gallus from } \\
\text { Desjardins and Morais (1990) GenBank no. NC001323; tlargely from Armstrong et al. (2001) and Kimball et al. (2001). }\end{array}$} \\
\hline \multicolumn{9}{|c|}{ 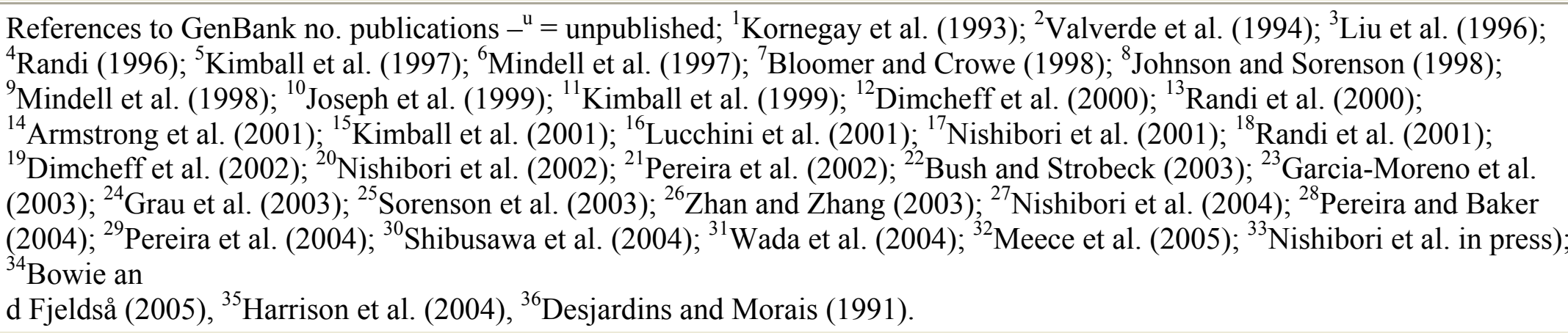 } \\
\hline
\end{tabular}




\section{Appendix 3}

Marginal posterior probabilities of the General Time Reversible Model obtained from a 5 million generation Bayesian inference run (burnin $=20 \%$ of the posterior distribution or $4000 / 20000$ sampling points). Parameters were obtained for each of the gene regions separately: (1) CYT B (2) ND2 (3) OVO-G (4) 12s and (5) CR

\begin{tabular}{|c|c|c|c|c|c|}
\hline \multirow[b]{2}{*}{ Parameter } & \multirow[b]{2}{*}{ Mean } & \multirow[b]{2}{*}{ Variance } & \multicolumn{3}{|c|}{ 95\% Credible Interval } \\
\hline & & & Lower & Upper & Median \\
\hline \multicolumn{6}{|c|}{ Rate matrices (General time reversible model of nucleotide evolution) } \\
\hline $\mathrm{r}(\mathrm{G} \doteqdot \mathrm{T})\{1\}$ & 1.00 & 0.00 & 1.00 & 1.00 & 1.00 \\
\hline $\mathrm{r}(\mathrm{C} \doteqdot \mathrm{T})\{1\}$ & 12.2 & 33.3 & 6.23 & 24.4 & 11.0 \\
\hline $\mathrm{r}(\mathrm{C} \leftrightarrows \mathrm{G})\{1\}$ & 0.89 & 0.23 & 0.37 & 1.96 & 0.79 \\
\hline $\mathrm{r}(\mathrm{A} \stackrel{*}{\rightarrow} \mathrm{T})\{1\}$ & 1.27 & 0.41 & 0.58 & 2.67 & 1.13 \\
\hline $\mathrm{r}(\mathrm{A} \doteqdot \mathrm{G})\{1\}$ & 20.4 & 87.4 & 10.4 & 41.1 & 18.4 \\
\hline $\mathrm{r}(\mathrm{A} \stackrel{*}{-} \mathrm{C})\{1\}$ & 0.36 & 0.03 & 0.17 & 0.75 & 0.33 \\
\hline $\mathrm{r}(\mathrm{G} \leftrightarrows \mathrm{T})\{2\}$ & 1.00 & 0.00 & 1.00 & 1.00 & 1.00 \\
\hline $\mathrm{r}(\mathrm{C} \leftrightarrows \mathrm{T})\{2\}$ & 3.99 & 0.58 & 2.81 & 5.66 & 3.87 \\
\hline $\mathrm{r}(\mathrm{C} \leftrightarrows \mathrm{G})\{2\}$ & 0.48 & 0.01 & 0.29 & 0.75 & 0.47 \\
\hline $\mathrm{r}(\mathrm{A} \leftrightarrows \mathrm{T})\{2\}$ & 0.32 & 0.01 & 0.20 & 0.51 & 0.31 \\
\hline $\mathrm{r}(\mathrm{A} \leftrightarrows \mathrm{G})\{2\}$ & 9.18 & 2.65 & 6.62 & 12.7 & 8.99 \\
\hline $\mathrm{r}(\mathrm{A} \stackrel{*}{\rightarrow} \mathrm{C})\{2\}$ & 0.18 & 0.00 & 0.12 & 0.27 & 0.18 \\
\hline $\mathrm{r}(\mathrm{G} \leftrightarrows \mathrm{T})\{3\}$ & 1.00 & 0.00 & 1.00 & 1.00 & 1.00 \\
\hline $\mathrm{r}(\mathrm{C} \leftrightarrows \mathrm{T})\{3\}$ & 2.55 & 0.20 & 1.80 & 3.53 & 2.51 \\
\hline $\mathrm{r}(\mathrm{C} \leftrightarrows \mathrm{G})\{3\}$ & 0.71 & 0.03 & 0.41 & 1.13 & 0.69 \\
\hline
\end{tabular}




\begin{tabular}{|c|c|c|c|c|c|}
\hline $\mathrm{r}(\mathrm{A} \leftrightarrows \mathrm{T})\{3\}$ & 1.10 & 0.05 & 0.71 & 1.61 & 1.07 \\
\hline $\mathrm{r}(\mathrm{A} \leftrightarrows \mathrm{G})\{3\}$ & 3.43 & 0.36 & 2.74 & 4.74 & 3.37 \\
\hline $\mathrm{r}(\mathrm{A} \leftrightarrows \mathrm{C})\{3\}$ & 1.17 & 0.07 & 0.74 & 1.74 & 1.15 \\
\hline $\mathrm{r}(\mathrm{G} \leftrightarrows \mathrm{T})\{4\}$ & 1.00 & 0.00 & 1.00 & 1.00 & 1.00 \\
\hline $\mathrm{r}(\mathrm{C} \doteqdot \mathrm{T})\{4\}$ & 74.1 & 305.1 & 38.8 & 99.0 & 76.3 \\
\hline $\mathrm{r}(\mathrm{C} \leftrightarrows \mathrm{G})\{4\}$ & 0.96 & 0.23 & 0.23 & 2.10 & 0.89 \\
\hline $\mathrm{r}(\mathrm{A} \stackrel{\star}{\rightarrow})\{4\}$ & 7.22 & 4.21 & 3.43 & 11.2 & 7.23 \\
\hline $\mathrm{r}(\mathrm{A} \doteqdot \mathrm{G})\{4\}$ & 31.7 & 77.9 & 15.7 & 49.5 & 31.4 \\
\hline $\mathrm{r}(\mathrm{A} \stackrel{*}{\rightarrow} \mathrm{C})\{4\}$ & 5.96 & 2.57 & 2.95 & 9.00 & 5.97 \\
\hline $\mathrm{r}(\mathrm{G} \stackrel{\leftarrow}{\leftrightarrows})\{5\}$ & 1.00 & 0.00 & 1.00 & 1.00 & 1.00 \\
\hline $\mathrm{r}(\mathrm{C} \doteqdot \mathrm{T})\{5\}$ & 4.51 & 0.42 & 3.45 & 5.94 & 4.45 \\
\hline $\mathrm{r}(\mathrm{C} \leftrightarrows \mathrm{G})\{5\}$ & 1.02 & 0.04 & 0.68 & 1.47 & 1.00 \\
\hline $\mathrm{r}(\mathrm{A} \stackrel{\leftarrow}{\rightarrow})\{5\}$ & 2.08 & 0.10 & 1.54 & 2.80 & 2.05 \\
\hline $\mathrm{r}(\mathrm{A} \leftrightarrows \mathrm{G})\{5\}$ & 4.33 & 0.40 & 0.27 & 5.76 & 4.28 \\
\hline $\mathrm{r}(\mathrm{A} \stackrel{\circ}{\leftrightarrows} \mathrm{C})\{5\}$ & 1.56 & 0.07 & 1.10 & 2.16 & 1.53 \\
\hline \multicolumn{6}{|c|}{ State (base) frequencies } \\
\hline $\operatorname{pi}(\mathrm{A})\{1\}$ & 0.346 & 0.000 & 0.325 & 0.369 & 0.347 \\
\hline $\operatorname{pi}(\mathrm{C})\{1\}$ & 0.448 & 0.000 & 0.427 & 0.467 & 0.448 \\
\hline $\operatorname{pi}(\mathrm{G})\{1\}$ & 0.051 & 0.000 & 0.046 & 0.057 & 0.051 \\
\hline $\operatorname{pi}(\mathrm{T})\{1\}$ & 0.154 & 0.000 & 0.146 & 0.163 & 0.154 \\
\hline $\operatorname{pi}(\mathrm{A})\{2\}$ & 0.350 & 0.000 & 0.331 & 0.371 & 0.350 \\
\hline $\operatorname{pi}(\mathrm{C})\{2\}$ & 0.412 & 0.000 & 0.393 & 0.431 & 0.413 \\
\hline
\end{tabular}




\begin{tabular}{|c|c|c|c|c|c|}
\hline $\operatorname{pi}(G)\{2\}$ & 0.052 & 0.000 & 0.047 & 0.057 & 0.052 \\
\hline $\operatorname{pi}(\mathrm{T})\{2\}$ & 0.185 & 0.000 & 0.174 & 0.196 & 0.185 \\
\hline $\operatorname{pi}(\mathrm{A})\{3\}$ & 0.225 & 0.000 & 0.199 & 0.254 & 0.225 \\
\hline $\operatorname{pi}(C)\{3\}$ & 0.223 & 0.000 & 0.195 & 0.251 & 0.222 \\
\hline $\operatorname{pi}(\mathrm{G})\{3\}$ & 0.226 & 0.000 & 0.198 & 0.256 & 0.226 \\
\hline $\operatorname{pi}(\mathrm{T})\{3\}$ & 0.326 & 0.000 & 0.294 & 0.358 & 0.326 \\
\hline $\operatorname{pi}(\mathrm{A})\{4\}$ & 0.357 & 0.000 & 0.329 & 0.385 & 0.357 \\
\hline $\operatorname{pi}(C)\{4\}$ & 0.327 & 0.000 & 0.302 & 0.352 & 0.327 \\
\hline $\operatorname{pi}(G)\{4\}$ & 0.148 & 0.000 & 0.127 & 0.170 & 0.148 \\
\hline $\operatorname{pi}(\mathrm{T})\{4\}$ & 0.168 & 0.000 & 0.151 & 0.185 & 0.167 \\
\hline $\operatorname{pi}(\mathrm{A})\{5\}$ & 0.263 & 0.000 & 0.242 & 0.286 & 0.263 \\
\hline $\operatorname{pi}(\mathrm{C})\{5\}$ & 0.255 & 0.000 & 0.234 & 0.276 & 0.255 \\
\hline $\operatorname{pi}(\mathrm{G})\{5\}$ & 0.142 & 0.000 & 0.125 & 0.159 & 0.142 \\
\hline $\operatorname{pi}(\mathrm{T})\{5\}$ & 0.338 & 0.000 & 0.316 & 0.362 & 0.338 \\
\hline \multicolumn{6}{|c|}{ Alpha shape parameter of the gamma distribution } \\
\hline alpha $\{1\}$ & 0.575 & 0.001 & 0.512 & 0.640 & 0.573 \\
\hline alpha $\{2\}$ & 0.773 & 0.002 & 0.692 & 0.858 & 0.773 \\
\hline alpha $\{3\}$ & 21.64 & 158.8 & 4.948 & 47.76 & 18.96 \\
\hline alpha $\{4\}$ & 0.748 & 0.011 & 0.543 & 0.961 & 0.746 \\
\hline alpha $\{5\}$ & 0.551 & 0.004 & 0.440 & 0.684 & 0.550 \\
\hline \multicolumn{6}{|c|}{ Proportion of invariable sites } \\
\hline $\operatorname{pinvar}\{1\}$ & 0.440 & 0.000 & 0.407 & 0.473 & 0.440 \\
\hline
\end{tabular}




\begin{tabular}{|l|l|l|l|l|l|}
\hline pinvar\{2\} & 0.326 & 0.000 & 0.293 & 0.359 & 0.326 \\
\hline $\operatorname{pinvar}\{3\}$ & 0.038 & 0.000 & 0.001 & 0.102 & 0.033 \\
\hline $\operatorname{pinvar}\{4\}$ & 0.430 & 0.000 & 0.362 & 0.486 & 0.432 \\
\hline $\operatorname{pinvar}\{5\}$ & 0.160 & 0.002 & 0.075 & 0.236 & 0.162 \\
\hline \hline
\end{tabular}

This article

- Abstract

- References

- Full Text HTML

- Full Text PDF (963 KB)

- Rights \& Permissions

\section{Search}

- Privacy Statement

- Terms \& Conditions

- Contact

- Help 
Fig. 1. The strict consensus morpho-behavioral parsimony cladogram from Dyke et al. (2003), including only taxa analyzed in the present study. Numbers above nodes in normal font are jackknife support values from a reanalysis of the data. Those in italics are bootstrap support values found in Dyke et al. (2003), but not in the reanalysis of the data for the taxa analyzed in the present study.

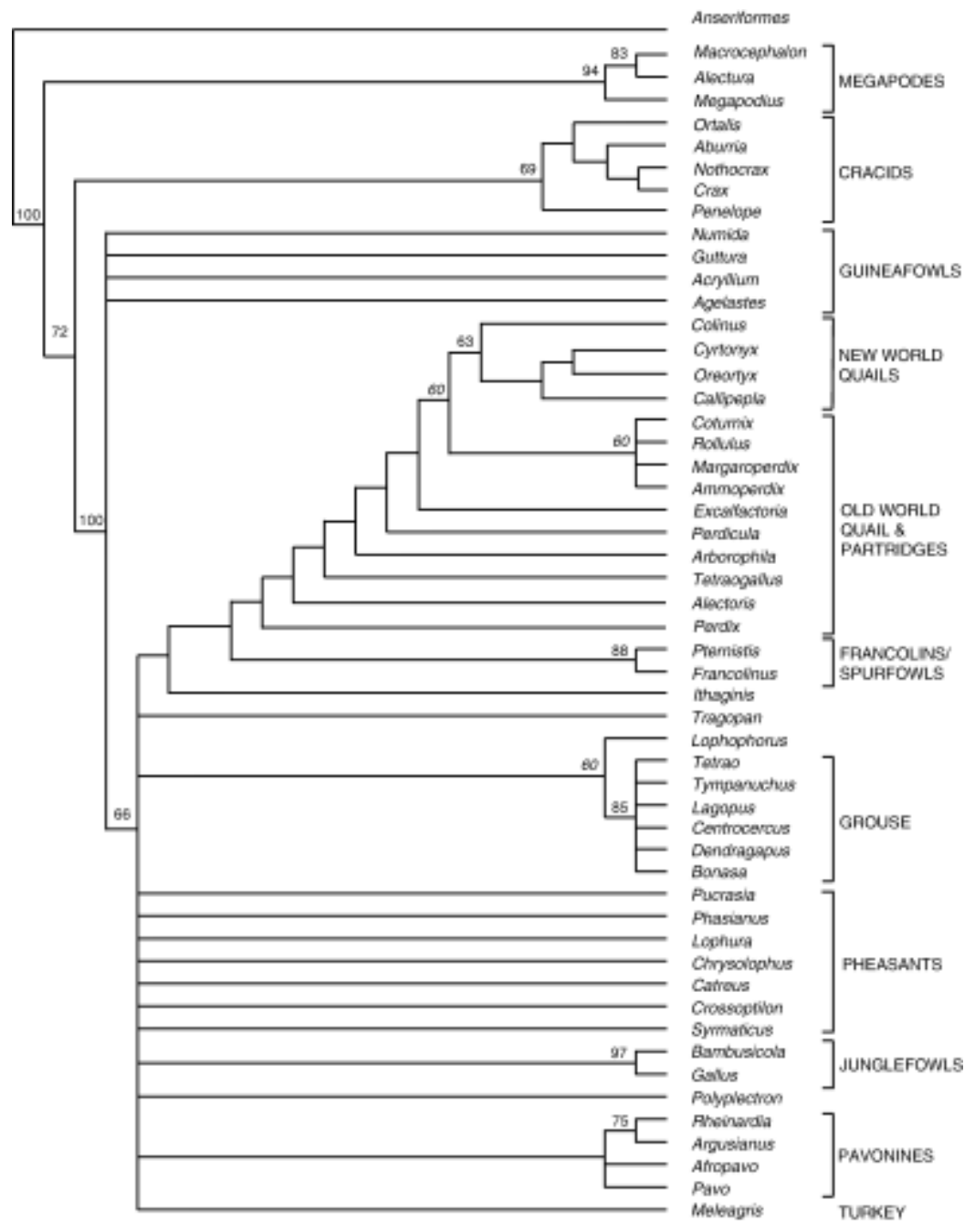


Fig. 2. A "traditional" classification/phylogeny for the galliform genera studied in here adapted from Johnsgard (1973, 1986, 1988, 1999), Jones et al. (1995), Delacour and Amadon (1973) and Crowe (1978).

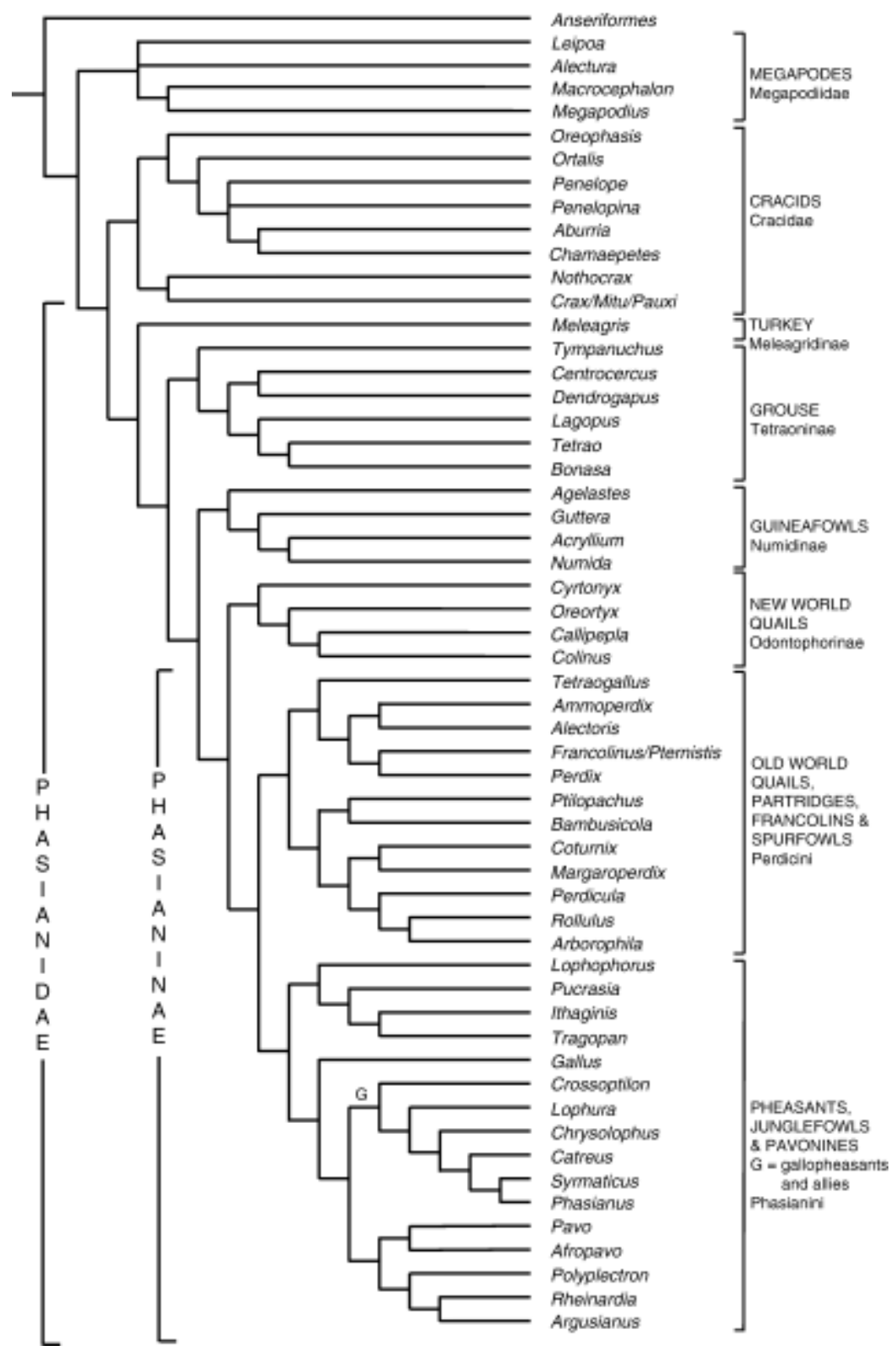


Fig. 3. Cladograms from various molecular phylogenetic analyses of gamebirds, methods of analysis and values for nodal support: (a) DNA-DNA hybridization, distance (Sibley and Ahlquist, 1990); (b) mitochondrial cytochrome $b$ sequences, parsimony (Kornegay et al., 1993); (c) mitochondrial cytochrome $b, 12$ s rDNA and ND2 sequences, Bayesian, bootstrap (Pereira and Baker, 2006); (d) mitochondrial cytochrome $b$ sequences, parsimony, bootstrap (Kimball et al., 1999); (e) nuclear intron ovomucoid G sequences, parsimony, bootstrap (Armstrong et al., 2001); (f) mitochondrial control region, parsimony, jackknife (Lucchini and Randi, 
openUP - February 2007

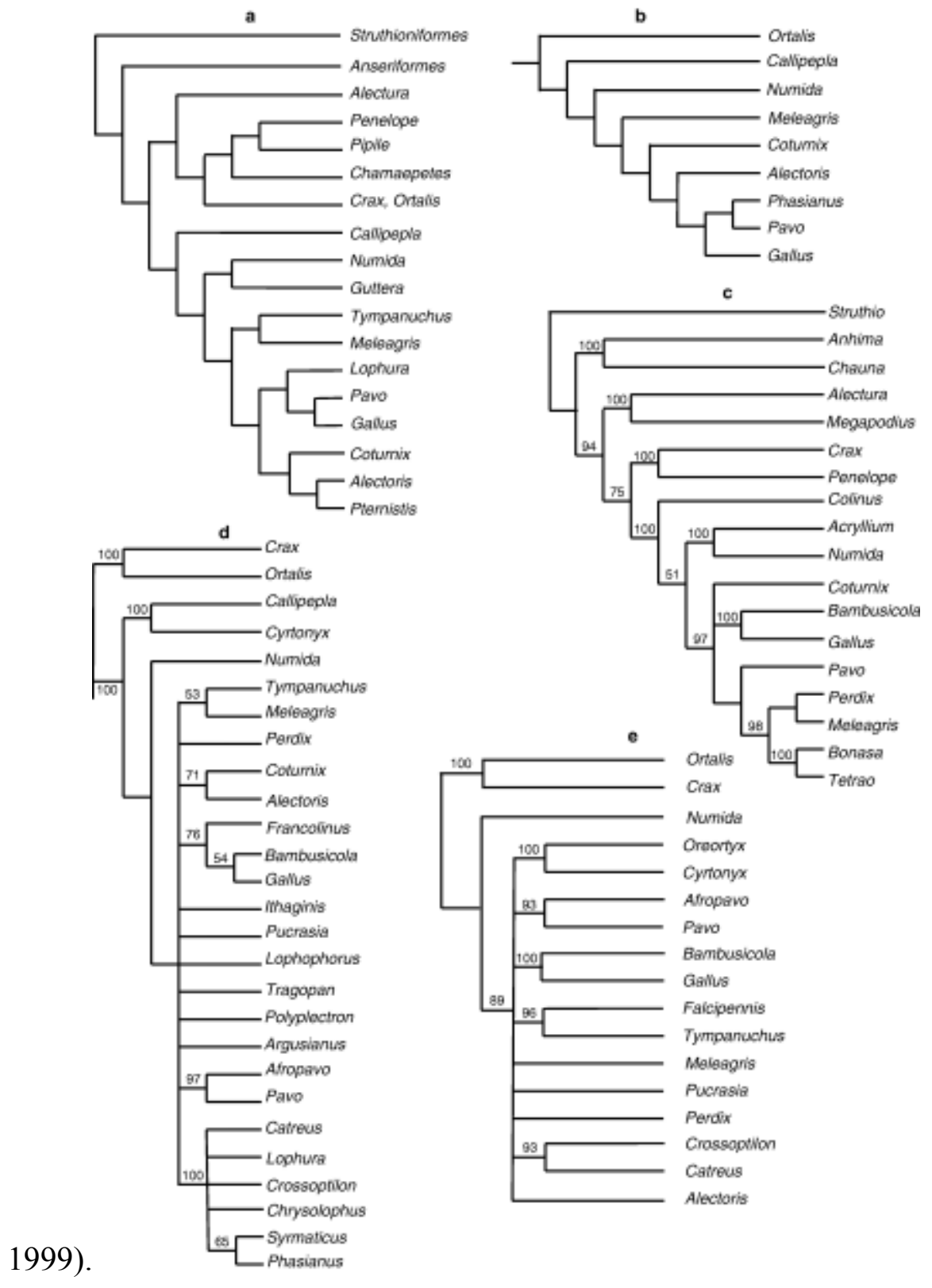


openUP - February 2007

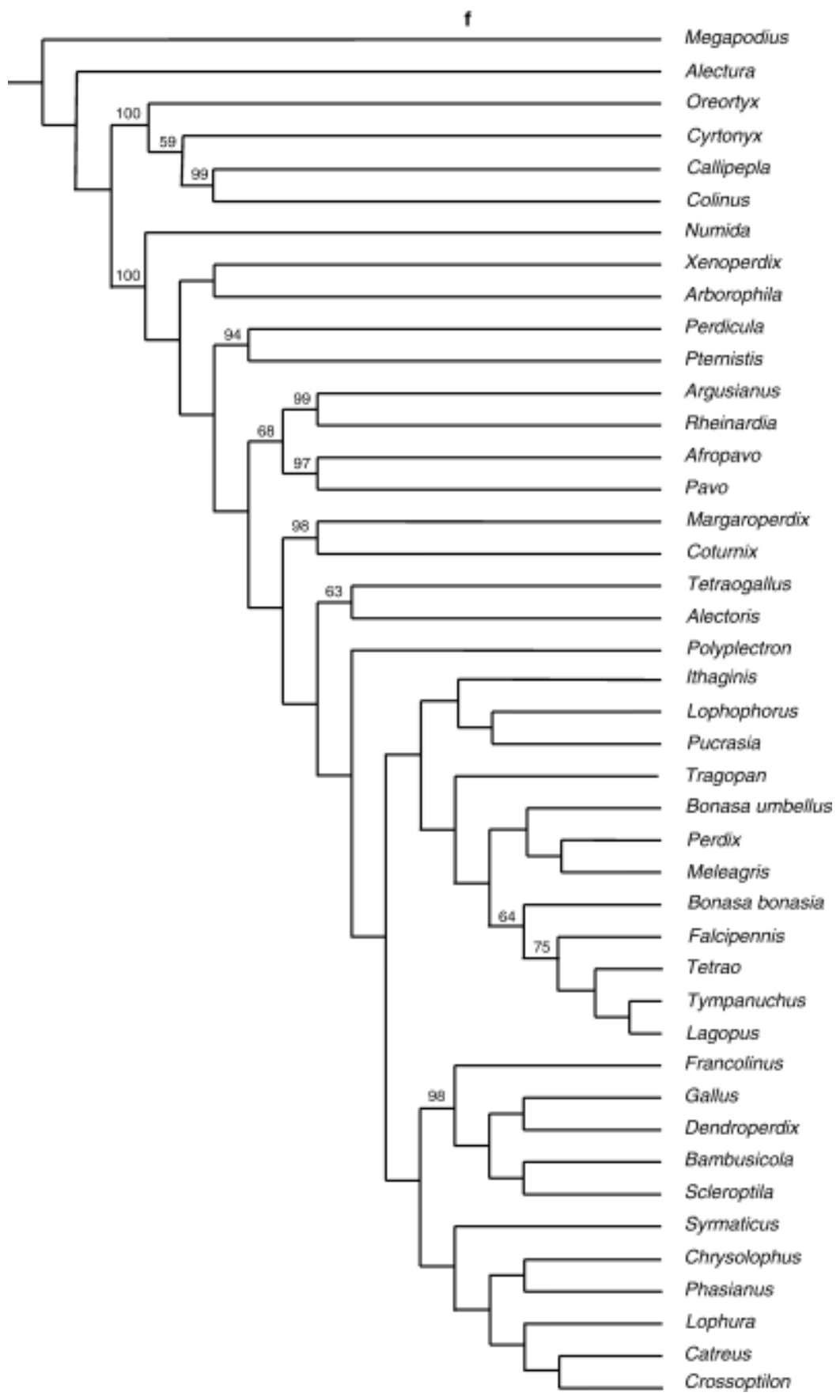


Fig. 4. The single most parsimonious cladogram of gamebird genera resulting from the parsimony ratchet analysis of the combined data set with biogeographical regions of occurrence. Numbers in bold italics at nodes indicate nodes mentioned in Table 4 and depicted in Fig. 10. Numbers in normal text above nodes are jackknife support values. Numbers below are Bayesian posterior probabilities. GW and AU indicate the placement of fossils, Gallinuloides wyomingensis (54 Ma) and Amitabha urbsinterdictensis (50 Ma), used as calibrations in the molecular clock analyses. Scientific names are those from our proposed revised classification.

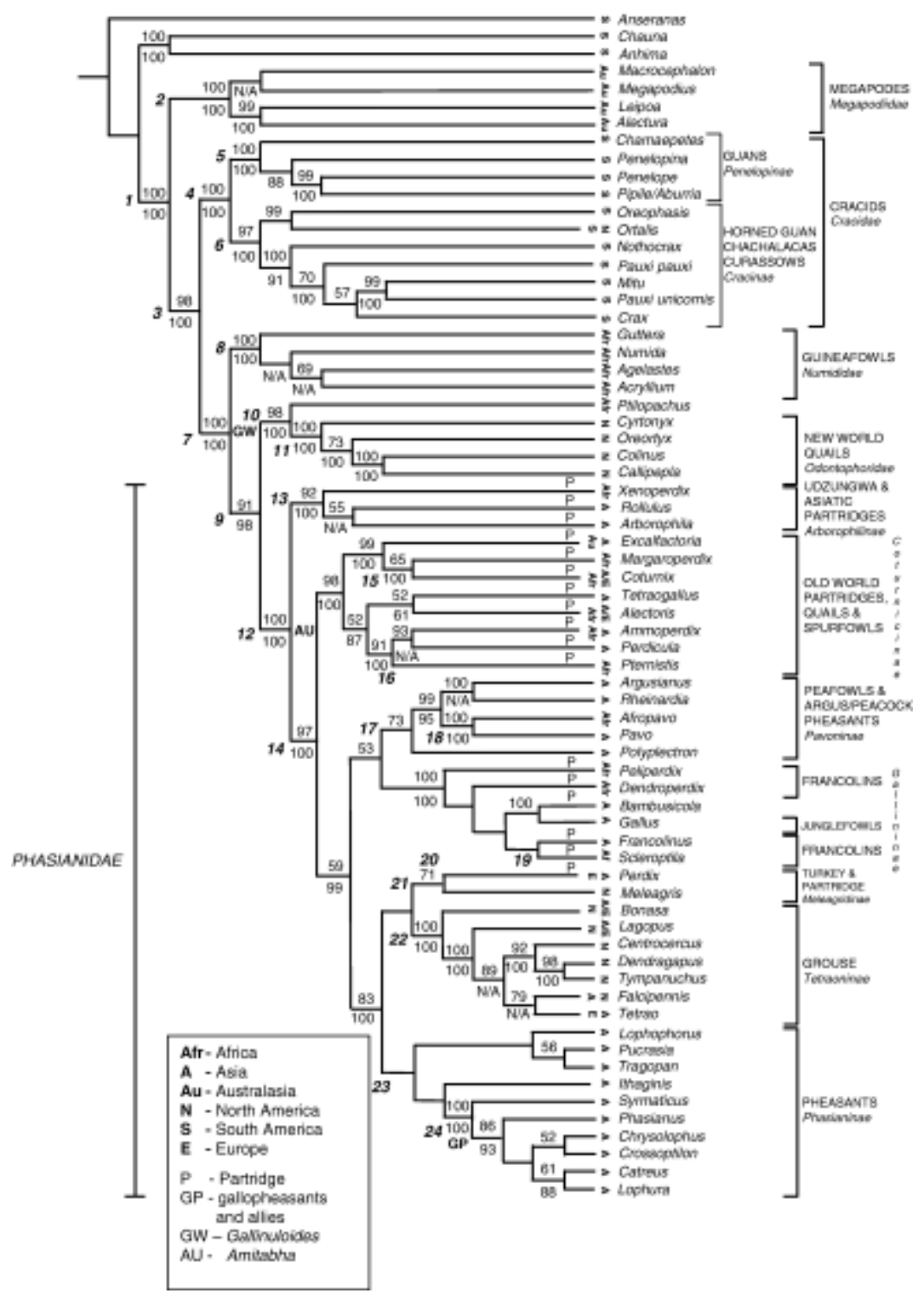


Fig. 5. The strict consensus cladogram for the cytochrome $b$ character partition with jackknife nodal support values. $\mathrm{C}=$ cracids, $\mathrm{M}=$ megapodes, $\mathrm{NWQ}=$ New World quails, $\mathrm{GF}=$ guineafowls, $\mathrm{GP}=$ gallopheasants and allies, $\mathrm{F}=$ francolins, and $\mathrm{SF}=$ spurfowls.

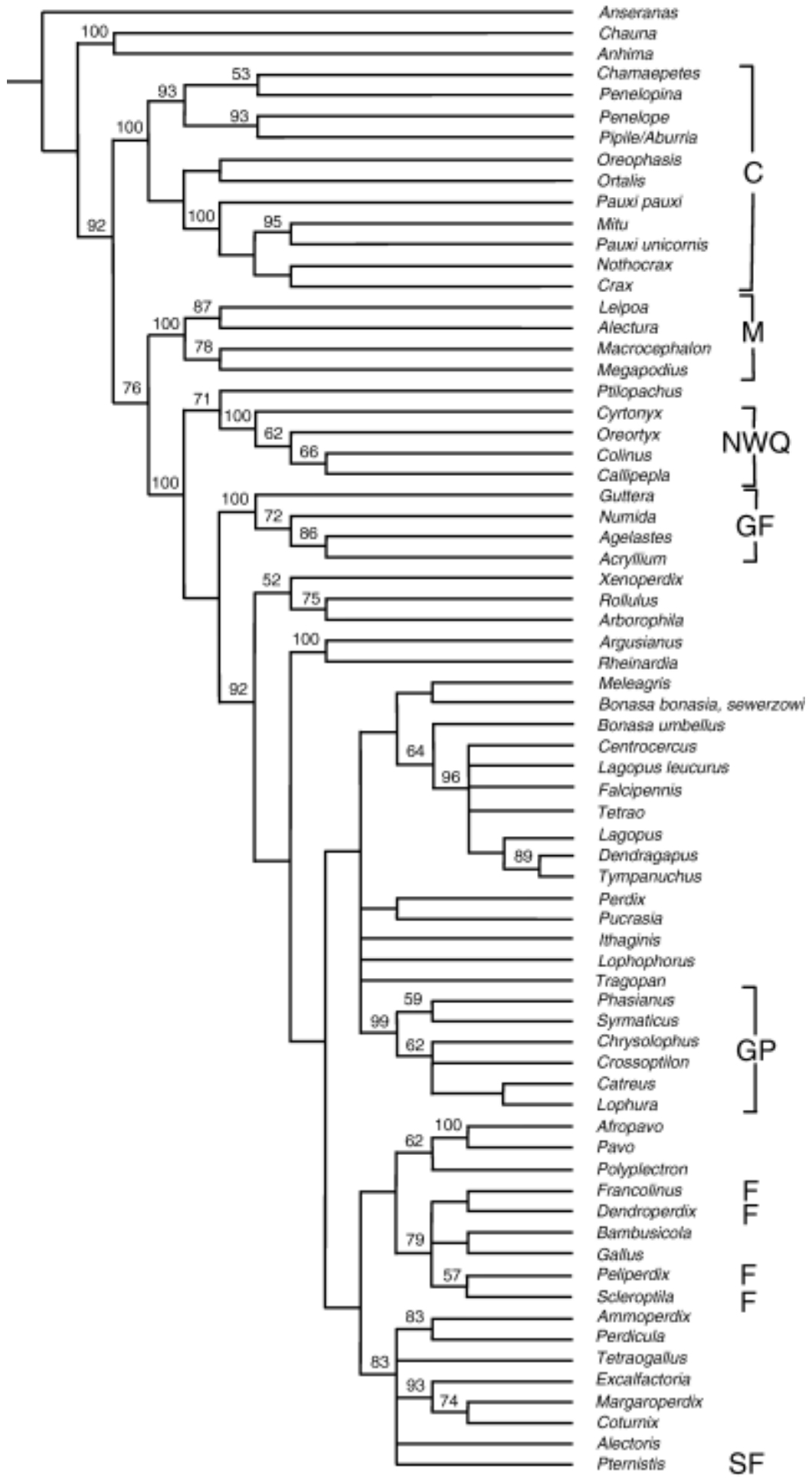


Fig. 6. The strict consensus cladogram for the NADH2 character partition with jackknife nodal support values. $\mathrm{M}=$ megapodes, $\mathrm{C}=$ cracids, $\mathrm{GF}=$ guineafowls, $\mathrm{NWQ}=\mathrm{New}$ World quails, $\mathrm{SF}=$ spurfowls, $\mathrm{F}=$ francolins, $\mathrm{PH}=$ pheasants, $\mathrm{GP}=$ gallopheasants and allies, and GR = grouse.

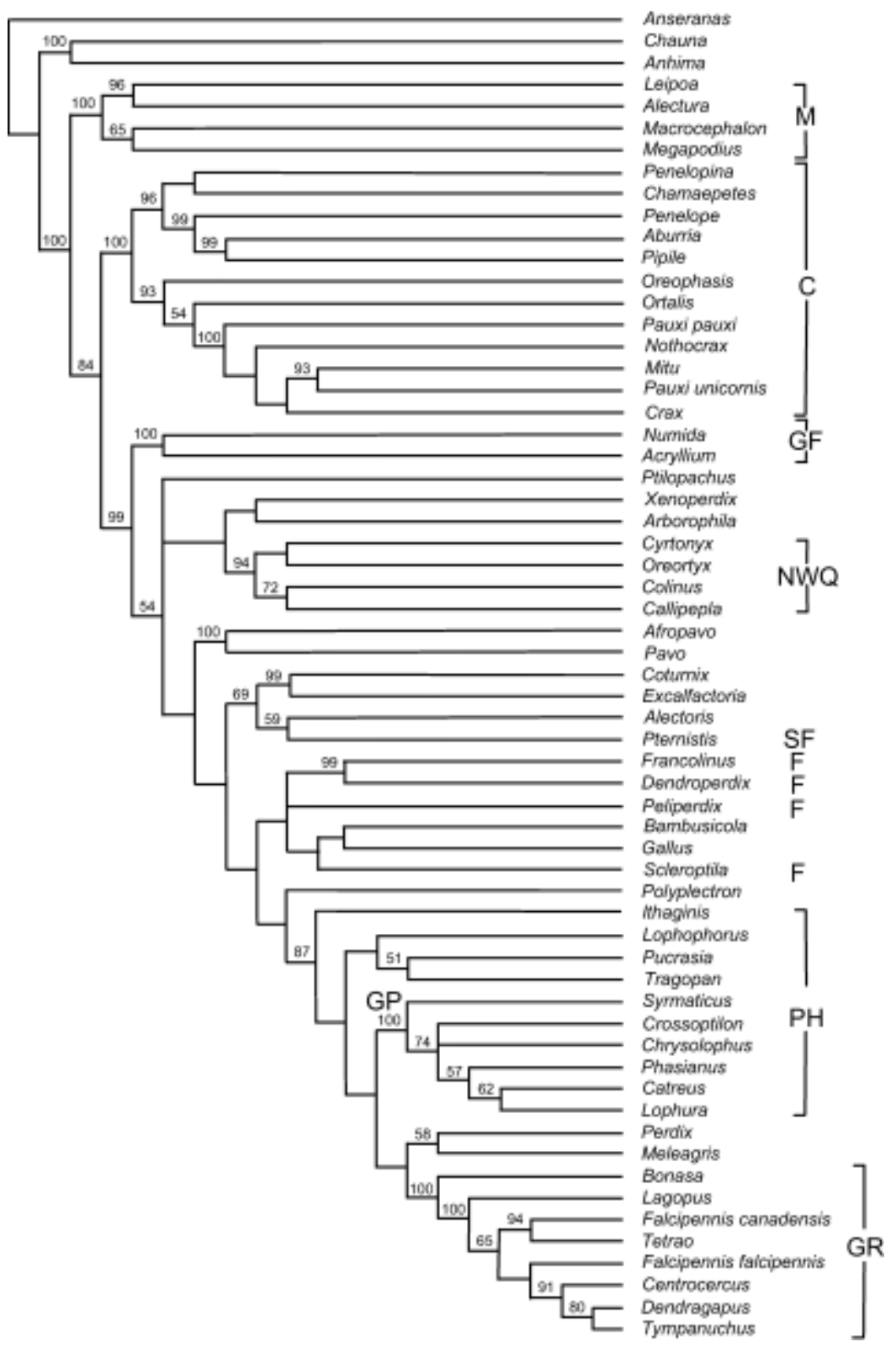


Fig. 7. The strict consensus cladogram for the control region character partition with jackknife nodal support values. $\mathrm{M}=$ megapodes, $\mathrm{C}=$ cracids, $\mathrm{GF}=$ guineafowl, $\mathrm{NWQ}=$ New World quails, $\mathrm{SF}=$ spurfowls, $\mathrm{PV}=$ pavonines, $\mathrm{F}=$ francolins, $\mathrm{GR}=$ grouse, $\mathrm{GP}=$ gallopheasants and allies, and $\mathrm{PH}=$ pheasants.

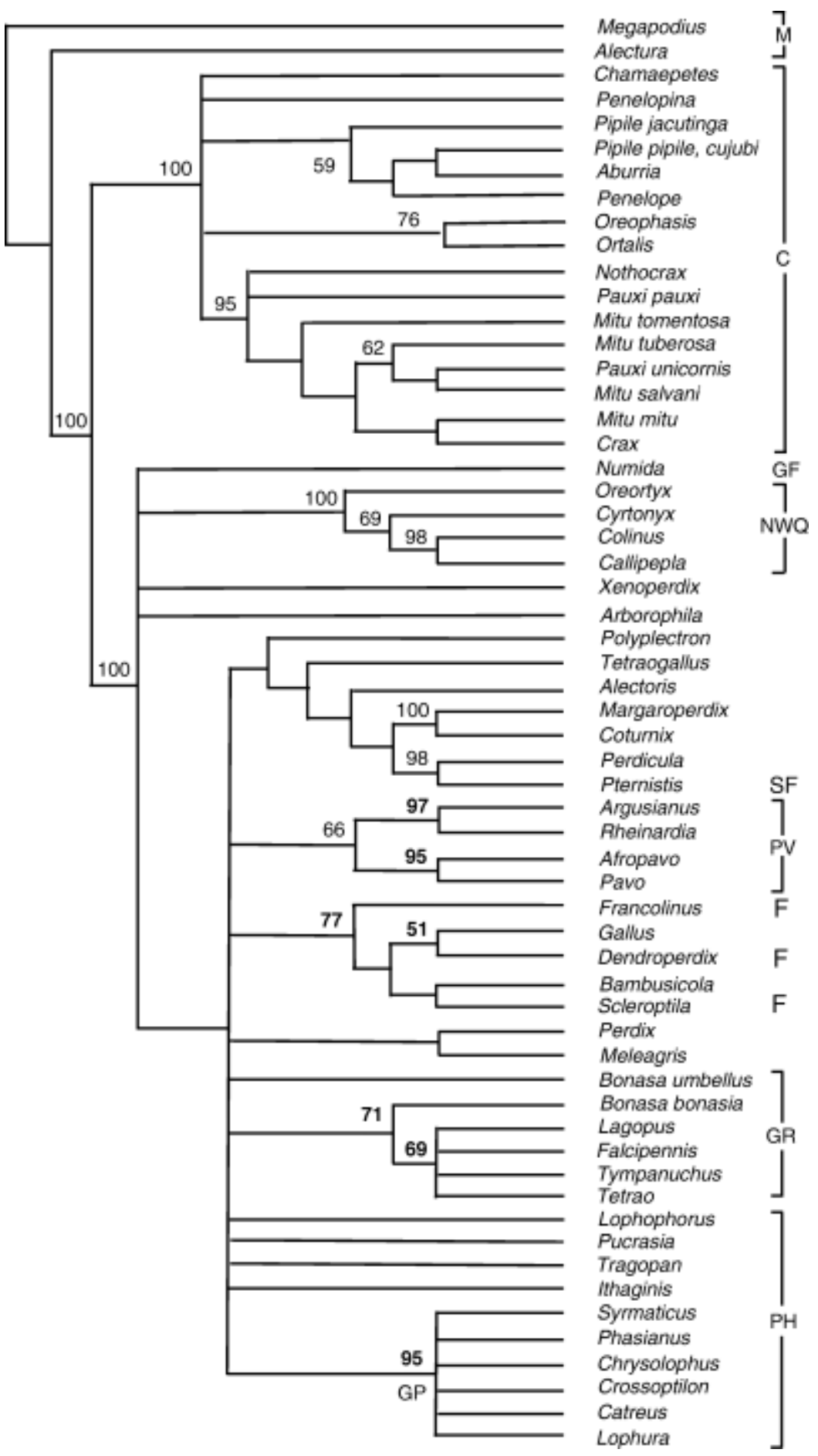


Fig. 8. The strict consensus cladogram for the $12 \mathrm{~S}$ rDNA character partition with jackknife nodal support values. $\mathrm{M}=$ megapodes, $\mathrm{C}=$ cracids, $\mathrm{GF}=$ guineafowls, $\mathrm{NWQ}=$ New World quail, $\mathrm{SF}=$ spurfowls, $\mathrm{F}=$ francolins, $\mathrm{GP}=$ gallopheasants and allies, $\mathrm{PH}=$ pheasants, and $\mathrm{GR}=$ grouse .

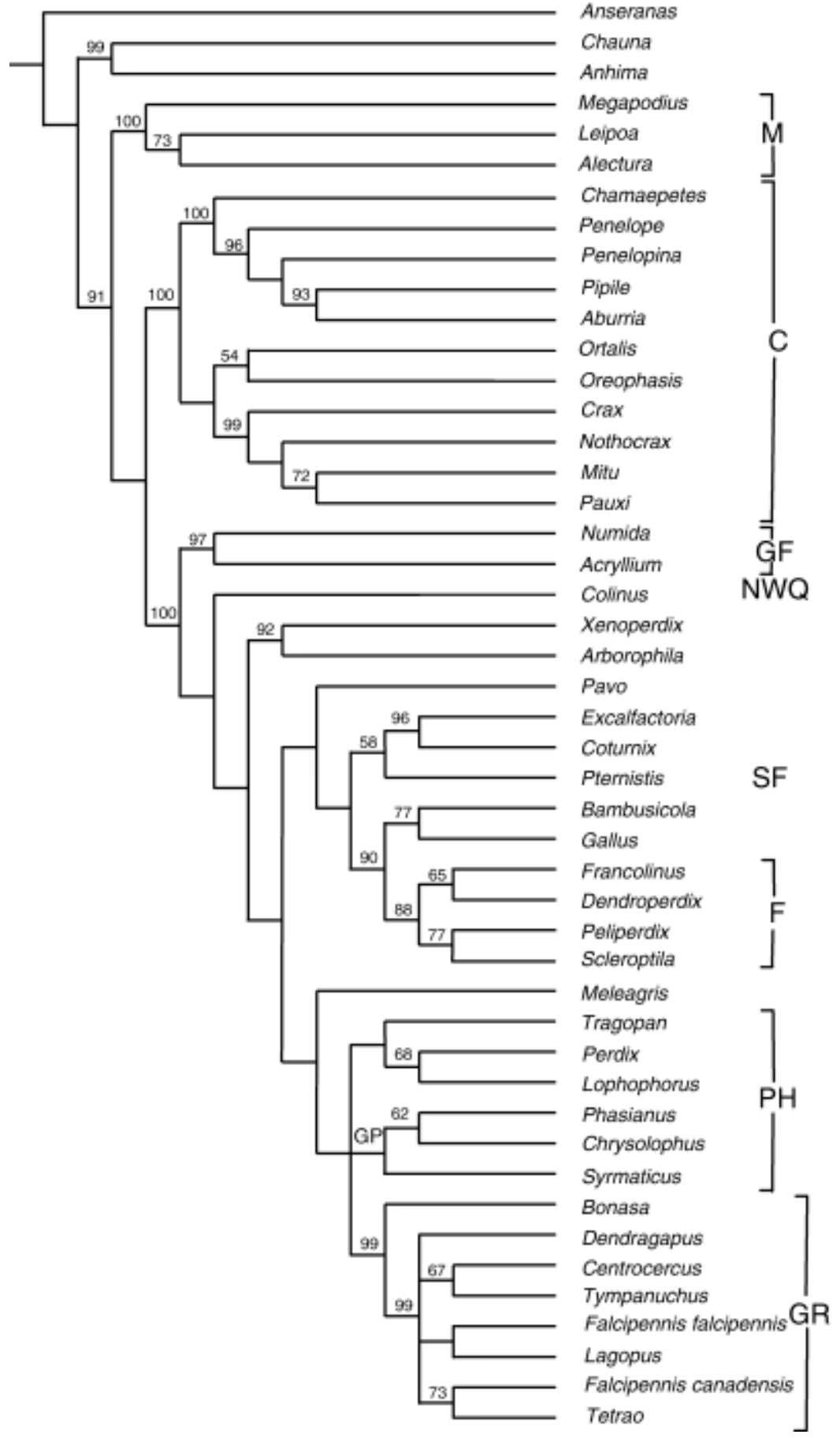


Fig. 9. The strict consensus cladogram for the ovomucoid $\mathrm{G}$ character partition with jackknife nodal support values. $\mathrm{M}=$ megapode, $\mathrm{C}=$ cracids, $\mathrm{GF}=$ guineafowls, $\mathrm{NWQ}=$ New World quails, $\mathrm{SF}=$ spurfowls, $\mathrm{GR}=$ grouse, $\mathrm{GP}=$ gallopheasants and allies, and $\mathrm{F}=$ francolins.

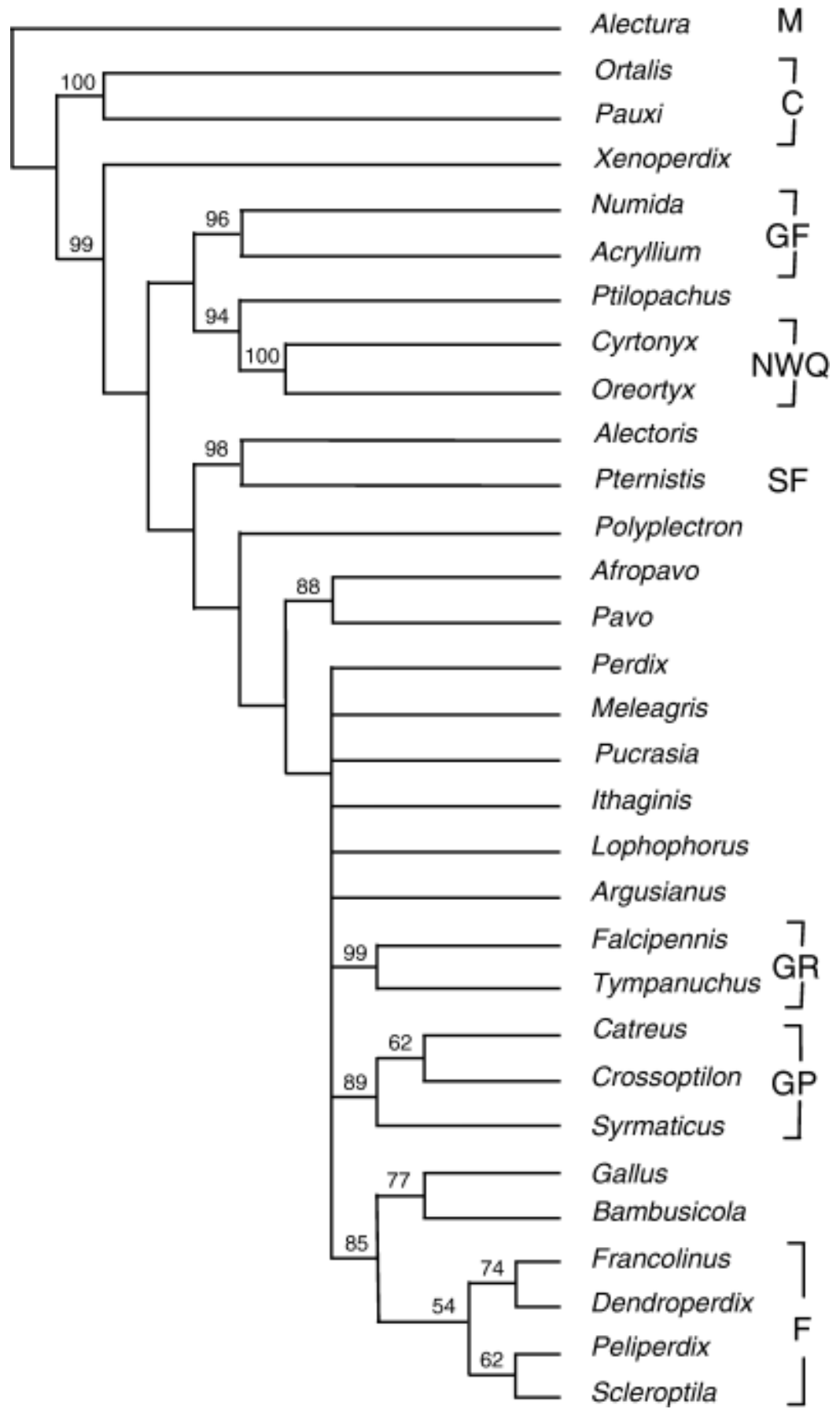


Fig. 10. Putative sexually selected characters mapped on to Fig. 4.

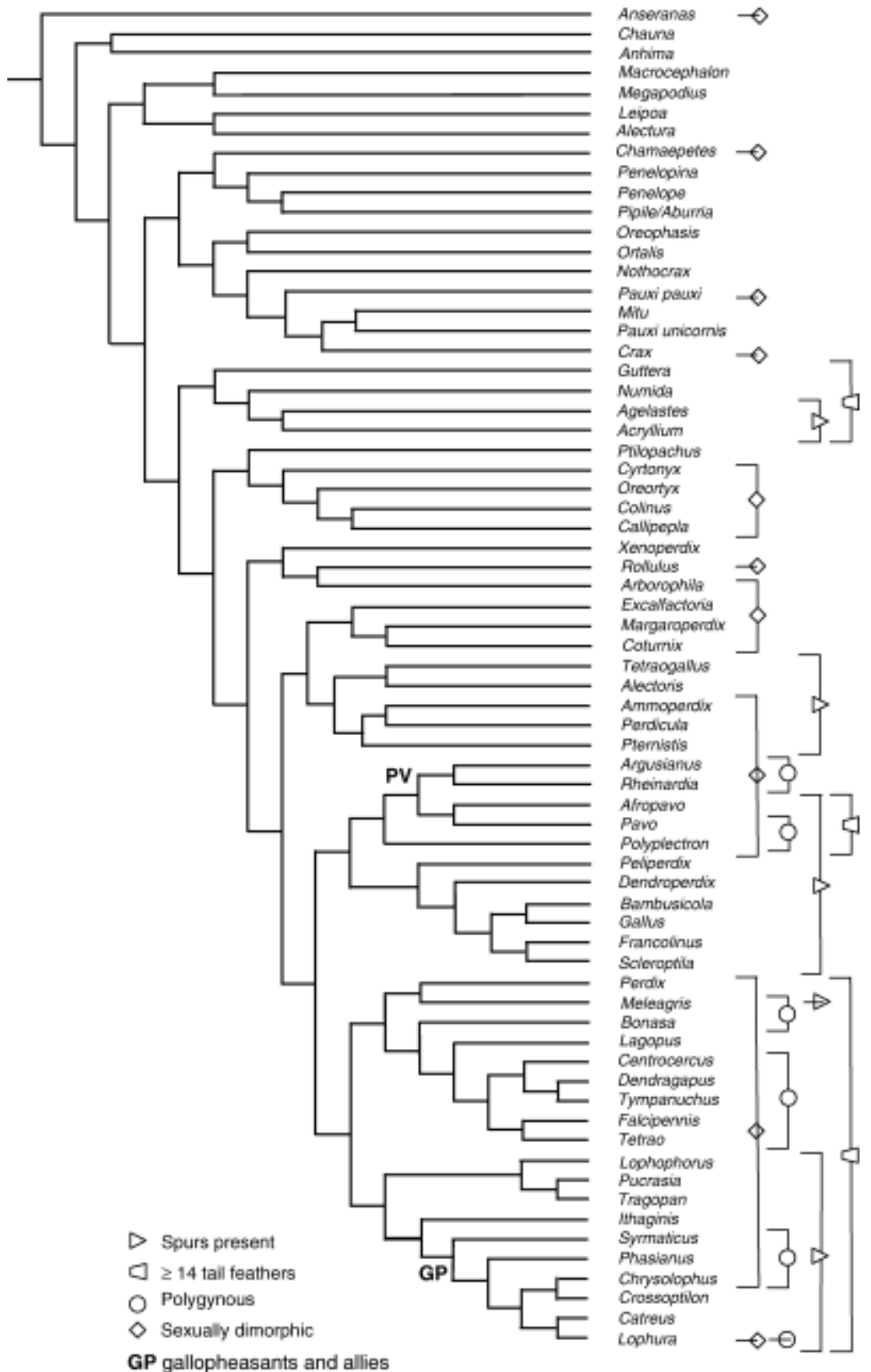

作

$\mathrm{PV}$ pavonines 
Table 1 Taxa attributed to the Galliformes by del Hoyo et al. (1994). Numbers in parentheses are those of species and genera investigated in this study

\begin{tabular}{|c|c|c|c|}
\hline Scientific and common names & Range & $\begin{array}{l}\text { No. of } \\
\text { species }\end{array}$ & $\begin{array}{l}\text { No. of } \\
\text { genera }\end{array}$ \\
\hline $\begin{array}{l}\text { Megapodiidae } \\
\text { megapodes, scrubfowl, } \\
\text { brush-turkeys }\end{array}$ & Australasian & $19(6)$ & $7(4)$ \\
\hline $\begin{array}{l}\text { Cracidae } \\
\text { cracids: curassows, guans and chachalacas }\end{array}$ & Neotropical & $50(28)$ & $\begin{array}{l}11 \\
(11)\end{array}$ \\
\hline $\begin{array}{l}\text { Numididae } \\
\text { guineafowls }\end{array}$ & Afrotropical & $6(5)$ & $4(4)$ \\
\hline $\begin{array}{l}\text { Phasianidae } \\
\text { pheasant-like birds }\end{array}$ & cosmopolitan & & \\
\hline $\begin{array}{l}\text { Phasianinae } \\
\text { pheasants, junglefowls (= chickens), peafowl } \\
\text { and peacock- and argus- } \\
\text { pheasants) }\end{array}$ & Afro/Asiotropical & $49(45)$ & $\begin{array}{l}16 \\
(16)\end{array}$ \\
\hline $\begin{array}{l}\text { Perdicinae } \\
\text { partridges, francolins and } \\
\text { Old World quails }\end{array}$ & $\begin{array}{l}\text { Palaearctic and } \\
\text { Afro/Asiotropical }\end{array}$ & $\begin{array}{l}106 \\
(49)\end{array}$ & $\begin{array}{l}26 \\
(18)\end{array}$ \\
\hline $\begin{array}{l}\text { Meleagrididae } \\
\text { turkeys }\end{array}$ & Nearctic & $2(1)$ & $1(1)$ \\
\hline $\begin{array}{l}\text { Tetraonidae } \\
\text { grouse }\end{array}$ & Holarctic & $17(17)$ & $7(7)$ \\
\hline $\begin{array}{l}\text { Odontophoridae } \\
\text { New World quails }\end{array}$ & $\begin{array}{l}\text { Neotropical } \\
\text { and Nearctic }\end{array}$ & $32(7)$ & $9(4)$ \\
\hline
\end{tabular}

Back to top 
Table 2 Primers used for DNA amplification and sequencing

\begin{tabular}{|c|c|c|c|}
\hline $\begin{array}{l}\text { Gene } \\
\text { region }\end{array}$ & $\begin{array}{l}\text { Primer } \\
\text { name }\end{array}$ & Primer sequence & Reference \\
\hline \multirow{2}{*}{$\begin{array}{l}\text { Cytochrome } \\
b \text { (initial } \\
\text { primer pair) }\end{array}$} & L14578 & 5'-CTAGGAATCATCCTAGCCCTAGA-3' & $\begin{array}{l}\text { J.G. Groth } \\
\text { pers. comm. }\end{array}$ \\
\hline & H16065 & $\begin{array}{l}\text { 5'- } \\
\text { AACGCAGTCATCTCCGGTTTACAAGAC- } \\
3^{\prime}\end{array}$ & $\begin{array}{l}\text { Irwin et al. } \\
(1991)\end{array}$ \\
\hline (internal) & L15236 & 5'-TTCCTATACAAAGAAACCTGAAA-3' & $\begin{array}{l}\text { Edwards } \\
\text { et al. (1991) }\end{array}$ \\
\hline \multirow[t]{2}{*}{$\begin{array}{l}\text { (galliform } \\
\text { specific) }\end{array}$} & ML15131 & 5'-AACGTACAGTACGGCTGACTCAT-3' & $\begin{array}{l}\text { P. Beresford } \\
\text { pers. comm. }\end{array}$ \\
\hline & MH15907 & 5'-TGTTCTACTGGTTGGCTTCCAAT-3' & \\
\hline \multirow[t]{2}{*}{ ND2 } & L5216 & 5'-GCCCATACCCCRAAAATG-3' & $\begin{array}{l}\text { Sorenson } \\
\text { et al. (1999) }\end{array}$ \\
\hline & H6313 & 5'-CTCTTATTTAAGGCTTTGAAGGC-3' & \\
\hline \multirow[t]{2}{*}{ OVO-G } & Forward & 5'-CAAGACATACGGCAACAARTG-3' & $\begin{array}{l}\text { Armstrong } \\
\text { et al. (2001) }\end{array}$ \\
\hline & Reverse & 5'-GGCTTAAAGTGAGAGTCCCRTT-3' & \\
\hline \multirow[t]{2}{*}{$12 \mathrm{~S}$ rDNA } & L1555 & 5'-AATCTTGTGCCAGCCACCGCGG-3' & $\begin{array}{l}\text { O. Haddrath } \\
\text { (S. Pereira, } \\
\text { pers.comm.) }\end{array}$ \\
\hline & H2241 & 5'- GTGCACCTTCCGGTACACTTACC-3' & \\
\hline
\end{tabular}

Back to top 
Table 3 Information on character data partitions

\begin{tabular}{|l|l|l|l|l|}
\hline \multicolumn{1}{|c|}{ Data set } & $\begin{array}{c}\text { No. of } \\
\text { chars }\end{array}$ & $\begin{array}{c}\text { No. of } \\
\text { in-group } \\
\text { taxa }\end{array}$ & $\begin{array}{c}\text { \% } \\
\text { missing } \\
\text { cells }\end{array}$ & $\begin{array}{c}\text { No. of } \\
\text { informative } \\
\text { chars }\end{array}$ \\
\hline Morpho-behavioral (M/B) & 102 & 158 & $<<1$ & 102 \\
\hline Mitochondrial cytochrome b (CYT B) & 1143 & 158 & 12 & 547 \\
\hline Mitochondrial ND2 (ND2) & 1041 & 119 & 42 & 594 \\
\hline Mitochondrial control region (CR) & 1046 & 97 & 53 & 418 \\
\hline Mitochondrial 12S rDNA (12S) & 731 & 69 & 61 & 302 \\
\hline Ovomucoid intron G (OVO-G) & 492 & 52 & 73 & 179 \\
\hline
\end{tabular}


Table 4 Resolution of selected nodes $(+=$ present in strict consensus tree without jackknife support, $-=$ not present) for the Galliformes in Fig. 4 and jackknife branch support values and (for the All DNA analysis only) Bayesian posterior probabilities from analyses of the combined data set (COMB) and various data partitions: combined minus ovomucoid G (C-OG), morpho-behavioral (M/B), cytochrome $b$ (CYT B), NADH2 (ND2), control region (CR), 12S rDNA (12S), ovomucoid G (OVO-G), all DNA partitions combined (All DNA), cytochrome $b+\mathrm{ND} 2$ minus 3rd positions (CYT B + ND2 no. 3rd pos), cytochrome $b+\mathrm{ND} 2$ 3rd positions + CR + ovomucoid G + 12 rDNA (CYT B/ND2 3P + CR, OVO-G, 12S)

\begin{tabular}{|c|c|c|c|c|c|c|c|c|c|c|c|c|}
\hline $\begin{array}{c}\text { Node } \\
\text { in Fig. } 4\end{array}$ & $\begin{array}{l}\text { Node } \\
\text { no. }\end{array}$ & COMB & $\mathbf{M} / \mathbf{B}$ & $\begin{array}{c}\text { All } \\
\text { DNA }\end{array}$ & CYT B & ND2 & $\mathbf{C R}$ & $12 S$ & OVO-G & C-OG & $\begin{array}{c}\text { ND2 } \\
\text { CYT B+ } \\
\text { no. 3P }\end{array}$ & $\begin{array}{c}\text { CYT B/ND2 } \\
\text { 3P + CR, } \\
\text { OVO-G, 12S }\end{array}$ \\
\hline Galliformes & 1 & +100 & +100 & $\begin{array}{l}+100 \\
100 *\end{array}$ & +92 & +100 & N/A & +91 & N/A & +100 & + & +86 \\
\hline $\begin{array}{l}\text { Megapodes } \\
\text { sister to balance }\end{array}$ & 1 & +100 & +100 & $\begin{array}{l}+100 \\
100\end{array}$ & - & +100 & N/A & + & N/A & +100 & + & +86 \\
\hline $\begin{array}{l}\text { Megapodes } \\
\text { monophyletic }\end{array}$ & 2 & +100 & +94 & $\begin{array}{l}+100 \\
100\end{array}$ & +100 & +100 & N/A & +100 & N/A & +100 & +99 & +100 \\
\hline $\begin{array}{l}\text { Cracids } \\
\text { sister to balance }\end{array}$ & 3 & +98 & +72 & $\begin{array}{l}+99 \\
100\end{array}$ & - & +84 & +100 & + & + & +100 & +100 & +83 \\
\hline $\begin{array}{l}\text { Cracids } \\
\text { monophyletic }\end{array}$ & 4 & +100 & +69 & $\begin{array}{l}+100 \\
100\end{array}$ & +100 & +100 & +100 & +100 & +100 & +100 & + & +100 \\
\hline $\begin{array}{l}\text { Penelopinae } \\
\text { monophyletic }\end{array}$ & 5 & +100 & - & $\begin{array}{l}+100 \\
100\end{array}$ & +93 & +96 & $\mathrm{UN}+$ & +100 & N/A & +100 & + & +96 \\
\hline $\begin{array}{l}\text { Cracinae } \\
\text { monophyletic }\end{array}$ & 6 & +97 & - & $\begin{array}{l}+98 \\
100\end{array}$ & + & +93 & UN & + & N/A & +100 & + & +68 \\
\hline $\begin{array}{l}\text { Guineafowls } \\
\text { sister to balance }\end{array}$ & 7 & +100 & +100 & $\begin{array}{l}+100 \\
100\end{array}$ & - & +99 & UN & + & - & +100 & - & +100 \\
\hline Guineafowls & 8 & +100 & UN & +100 & +100 & +100 & $\mathrm{~N} / \mathrm{A}$ & +97 & +96 & +100 & + & +100 \\
\hline
\end{tabular}




\begin{tabular}{|c|c|c|c|c|c|c|c|c|c|c|c|c|}
\hline $\begin{array}{c}\text { Node } \\
\text { in Fig. } 4\end{array}$ & $\begin{array}{l}\text { Node } \\
\text { no. }\end{array}$ & COMB & M/B & $\begin{array}{c}\text { All } \\
\text { DNA }\end{array}$ & CYT B & ND2 & CR & 12S & OVO-G & C-OG & $\begin{array}{c}\text { ND2 } \\
\text { CYT B+ } \\
\text { no. 3P }\end{array}$ & $\begin{array}{c}\text { CYT B/ND2 } \\
\text { 3P + CR, } \\
\text { OVO-G, 12S }\end{array}$ \\
\hline monophyletic & & & & 100 & & & & & & & & \\
\hline $\begin{array}{l}\text { New World quails } \\
\text { sister to balance }\end{array}$ & 9 & +91 & - & $\begin{array}{l}+79 \\
100\end{array}$ & - & - & UN & + & - & +86 & - & + \\
\hline $\begin{array}{l}\text { Ptilopachus sister } \\
\text { to New World quails }\end{array}$ & 10 & +98 & N/A & $\begin{array}{l}+98 \\
100\end{array}$ & +71 & - & N/A & N/A & +94 & +94 & - & +59 \\
\hline $\begin{array}{l}\text { New World quails } \\
\text { monophyletic }\end{array}$ & 11 & +100 & +63 & $\begin{array}{l}+100 \\
100\end{array}$ & +100 & +94 & +100 & N/A & +100 & +100 & +71 & +100 \\
\hline $\begin{array}{l}\text { Xenoperdix clade } \\
\text { sister to balance }\end{array}$ & 12 & +100 & $\mathrm{~N} / \mathrm{A}$ & $\begin{array}{l}+99 \\
100\end{array}$ & + & - & UN & + & - & +97 & - & + \\
\hline $\begin{array}{l}\text { Xenoperdix clade } \\
\text { monophyletic }\end{array}$ & 13 & +92 & N/A & $\begin{array}{l}+96 \\
100\end{array}$ & +52 & + & UN & +92 & N/A & +92 & - & + \\
\hline $\begin{array}{l}\text { Margaroperdix } \\
\text { sister to Coturnix }\end{array}$ & 15 & +65 & UN & $\begin{array}{l}+79 \\
100\end{array}$ & +74 & N/A & +100 & N/A & $\mathrm{N} / \mathrm{A}$ & +61 & - & +85 \\
\hline $\begin{array}{l}\text { Pavoninae } \\
\text { monophyletic }\end{array}$ & 17 & +73 & UN & - & +62 & - & - & $\mathrm{N} / \mathrm{A}$ & PARA & +66 & - & + \\
\hline $\begin{array}{l}\text { Afropavo } \\
\text { sister to Pavo }\end{array}$ & 18 & +100 & UN & $\begin{array}{l}+100 \\
100\end{array}$ & +100 & +100 & +95 & N/A & +88 & +100 & +90 & +100 \\
\hline $\begin{array}{l}\text { Bambusicola } \\
\text { sister to Gallus }\end{array}$ & 19 & +100 & +97 & $\begin{array}{l}+78 \\
100\end{array}$ & + & + & - & +77 & +77 & +100 & - & +59 \\
\hline $\begin{array}{l}\text { Perdix } \\
\text { sister to Meleagris }\end{array}$ & 21 & +71 & - & $\begin{array}{l}+79 \\
-\end{array}$ & - & +58 & + & - & UN & +79 & - & +61 \\
\hline $\begin{array}{l}\text { Tetraoninae } \\
\text { monophyletic }\end{array}$ & 22 & +100 & +85 & $\begin{array}{l}+98 \\
100\end{array}$ & - & +100 & UN & +99 & +99 & +100 & +72 & +64 \\
\hline Phasianinae & 23 & + & - & + & - & PARA & UN & - & UN & - & - & + \\
\hline
\end{tabular}




\begin{tabular}{|c|c|c|c|c|c|c|c|c|c|c|c|c|}
\hline $\begin{array}{c}\text { Node } \\
\text { in Fig. } 4\end{array}$ & $\begin{array}{l}\text { Node } \\
\text { no. }\end{array}$ & COMB & $\mathbf{M} / \mathbf{B}$ & $\begin{array}{c}\text { All } \\
\text { DNA }\end{array}$ & CYT B & ND2 & CR & 12S & OVO-G & C-OG & $\begin{array}{c}\text { ND2 } \\
\text { CYT B+ } \\
\text { no. } 3 P\end{array}$ & $\begin{array}{c}\text { CYT B/ND2 } \\
\text { 3P + CR, } \\
\text { OVO-G, 12S }\end{array}$ \\
\hline $\begin{array}{l}\text { minus Gallus } \\
\text { monophyletic }\end{array}$ & & & & - & & & & & & & & \\
\hline $\begin{array}{l}\text { Gallopheasants } \\
\text { and allies } \\
\text { monophyletic }\end{array}$ & 24 & 100 & UN & $\begin{array}{l}+100 \\
100\end{array}$ & +99 & +100 & +95 & + & +89 & +100 & + & +100 \\
\hline
\end{tabular}

Back to top 
Table 5 Evolutionary timescale in millions of years for selected nodes in the combined-data cladogram for the Galliformes (Fig. 4)

\begin{tabular}{|c|c|c|c|c|c|c|c|c|c|c|}
\hline \multirow{3}{*}{$\begin{array}{c}\text { Node } \\
\text { in Fig. } 4\end{array}$} & \multirow[t]{3}{*}{ Node no. } & \multicolumn{9}{|c|}{ Marker and inferred age (Ma) } \\
\hline & & \multicolumn{6}{|c|}{ Parsimony/Likelihood } & \multicolumn{3}{|c|}{ Bayesian } \\
\hline & & CYT B & ND2 & $12 S$ & CR & OVO-G & COMB & SD & LOWER & UPPER \\
\hline \multicolumn{11}{|l|}{ Origin of } \\
\hline Galliformes & 1 & 64.5 & 68.6 & 72.1 & $\mathrm{~N} / \mathrm{A}$ & N/A & 107.9 & 8.4 & 91.1 & 121.8 \\
\hline Stem Megapodiidae & & 68.7 & 76.4 & 79.0 & $\mathrm{~N} / \mathrm{A}$ & N/A & & & & \\
\hline Stem & 4 & 57.6 & 58.1 & 60.7 & 64.9 & 72.6 & 92.8 & 7.3 & 79.2 & 107.3 \\
\hline Cracidae & & 59.9 & 62.1 & 67.7 & 71.5 & 80.2 & & & & \\
\hline Stem & 8 & 54.0 & 54.0 & 54.0 & 54.0 & 54.0 & 60.2 & 4.7 & 53.3 & 71.3 \\
\hline Numididae & & 54.0 & 54.0 & 54.0 & 54.0 & 54.0 & & & & \\
\hline Stem Ptilopachus + & 10 & 51.5 & 49.8 & $\mathrm{~N} / \mathrm{A}$ & $\mathrm{N} / \mathrm{A}$ & 47.9 & 55.5 & 4.3 & 50.1 & 65.9 \\
\hline Odontophoridae & & 52.0 & 51.4 & N/A & $\mathrm{N} / \mathrm{A}$ & 49.6 & & & & \\
\hline \multirow[t]{2}{*}{ Stem Phasianidae } & \multirow[t]{2}{*}{12} & 50.3 & 48.0 & 48.2 & 50.0 & 51.8 & 55.5 & 4.3 & 50.1 & 65.9 \\
\hline & & 51.0 & 49.4 & 51.9 & 49.0 & 48.0 & & & & \\
\hline Stem Xenoperdix+ & 13 & 46.3 & 45.1 & 42.4 & 47.2 & N/A & 48.9 & 4.1 & 43.0 & 58.6 \\
\hline Arborophila & & 46.8 & 45.6 & 49.4 & 49.4 & N/A & & & & \\
\hline Margaroperdix/ & 15 & 14.2 & $\mathrm{~N} / \mathrm{A}$ & $\mathrm{N} / \mathrm{A}$ & 17.1 & N/A & 15.0 & 2.5 & 10.5 & 20.6 \\
\hline Coturnix & & 17.2 & $\mathrm{~N} / \mathrm{A}$ & N/A & 18.1 & $\mathrm{~N} / \mathrm{A}$ & & & & \\
\hline Stem Pternistis & 16 & 31.0 & 32.7 & 29.8 & 35.1 & 28.1 & 32.5 & 3.3 & 27.0 & 40.0 \\
\hline
\end{tabular}




\begin{tabular}{|c|c|c|c|c|c|c|c|c|c|c|}
\hline \multirow{3}{*}{$\begin{array}{c}\text { Node } \\
\text { in Fig. } 4\end{array}$} & \multirow[t]{3}{*}{ Node no. } & \multicolumn{9}{|c|}{ Marker and inferred age (Ma) } \\
\hline & & \multicolumn{6}{|c|}{ Parsimony/Likelihood } & \multicolumn{3}{|c|}{ Bayesian } \\
\hline & & CYT B & ND2 & $12 S$ & CR & OVO-G & COMB & SD & LOWER & UPPER \\
\hline & & 33.3 & 35.9 & 31.7 & 36.3 & 29.5 & & & & \\
\hline \multirow[t]{2}{*}{ Stem Pavoninae } & \multirow[t]{2}{*}{17} & 40.1 & 39.1 & $\mathrm{~N} / \mathrm{A}$ & 30.5 & 33.0 & 38.6 & 3.5 & 32.9 & 46.9 \\
\hline & & 41.8 & 42.5 & $\mathrm{~N} / \mathrm{A}$ & 32.1 & 36.6 & & & & \\
\hline \multirow[t]{2}{*}{ Afropavo/Pavo } & \multirow[t]{2}{*}{18} & 17.5 & 15.4 & $\mathrm{~N} / \mathrm{A}$ & 18.4 & 18.0 & 17.1 & 2.4 & 12.7 & 22.4 \\
\hline & & 17.0 & 17.3 & $\mathrm{~N} / \mathrm{A}$ & 18.9 & 19.1 & & & & \\
\hline Bambusicola/ & 19 & 23.1 & 23.6 & 14.9 & 16.0 & 11.9 & 24.1 & 2.8 & 19.3 & 30.4 \\
\hline Gallus & & 24.9 & 24.9 & 15.9 & 17.6 & 12.5 & & & & \\
\hline \multirow[t]{2}{*}{ Stem Scleroptila } & \multirow[t]{2}{*}{20} & 17.2 & 26.6 & 19.9 & 19.4 & 19.6 & 28.3 & 3.0 & 23.3 & 35.2 \\
\hline & & 19.4 & 30.3 & 24.3 & 19.6 & 23.9 & & & & \\
\hline \multirow[t]{2}{*}{ Stem Tetraoninae } & \multirow[t]{2}{*}{22} & 35.6 & 32.9 & 30.3 & 30.4 & 26.8 & 36.2 & 3.4 & 30.8 & 44.1 \\
\hline & & 37.2 & 33.0 & 34.6 & 30.5 & 34.6 & & & & \\
\hline \multicolumn{11}{|c|}{$\begin{array}{l}\text { CYT B, cytochrome } b \text {; ND2, NADH dehydrogenase subunit } 2 ; 12 \mathrm{~S}, 12 \text { rDNA; CR, control region; OVO-G, intron ovomucoid } \\
\text { G; COMB, Bayesian estimate for the combined molecular markers; SD, standard deviation of COMB; LOWER, lower } 95 \% \\
\text { credible interval; UPPER, upper } 95 \% \text { credible interval. }\end{array}$} \\
\hline
\end{tabular}

